\title{
Environmental changes during the Holocene climatic optimum in central Europe - human impact and natural causes
}

\author{
Arie J. Kalis ${ }^{\mathrm{a}}$, Josef Merkt ${ }^{\mathrm{b}}$, Jürgen Wunderlich ${ }^{\mathrm{c}, *}$ \\ ${ }^{a}$ Seminar für Vor- und Frühgeschichte, J.W. Goethe-Universität Frankfurt am Main, D-60054 Frankfurt am Main, Germany \\ ${ }^{\mathrm{b}}$ Ritter-Eccartstraße 5, D-88518 Herbertingen, Germany \\ ${ }^{\mathrm{c}}$ Institut für Physische Geographie, J.W. Goethe-Universität Frankfurt am Main, D-60054 Frankfurt am Main, Germany
}

\begin{abstract}
The priority programme "Changes of the Geo-Biosphere" aimed to reconstruct the environmental history of central Europe with emphasis on the time interval from 9000 to 5500 cal BP (time-slice II), coinciding with the Holocene climatic optimum. During this period, the onset of human activities such as settlement, agriculture and animal husbandry caused environmental changes. Studies of different landscape units in Germany were carried out to identify these anthropogenically induced changes and to distinguish them from natural effects on the environmental system. The investigated archives included laminated lake sediments, fluvial sediments, colluvia and soils, speleothems, peat and coastal sediments. The different archives were examined using refined research methods including a variety of sedimentary and geochemical analyses, together with pollen analysis and dating methods for the establishment of a reliable chronology. The results of the various research groups are summarised and critically discussed. Based on these results, the climatic optimum can be subdivided into three periods: (1) the Early Atlantic from 9000 to 7500 cal BP with negligible human impact and stable environmental conditions; (2) the Late Atlantic during Early and Middle Neolithic from 7500 to 6300 cal BP with pollen evidence for vegetation changes but only negligible changes detectable in other proxy records; and (3) the Late Atlantic during the Younger Neolithic (Jungneolithikum), after 6300 cal BP, with human impact observed in many archives and proxy records especially in the pollen record but also in lacustrine and fluvial sediments. During the whole climatic optimum natural causes, such as minor shifts of temperature, did not induce substantial environmental changes, though some changes, such as temporary droughts, may have facilitated and amplified the observed human impact.
\end{abstract}

(C) 2002 Elsevier Science Ltd. All rights reserved.

\section{Contents}

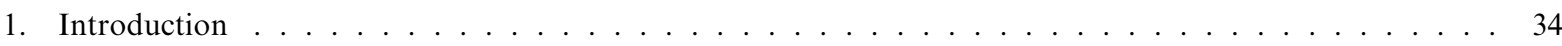

2. First human impact as reflected in pollen records from different regions in Germany . . . . . . . . . . 34

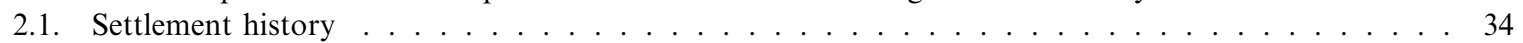

2.2. Palynological reflection of early farming activities . . . . . . . . . . . . . . . . . . . . . . 37

2.2.1. Non-arboreal pollen component and, in particular, cultural indicators . . . . . . . . . . 38

2.2.2. Arboreal pollen component . . . . . . . . . . . . . . . . . . . . . . . 39

2.3. Regions (from south to north) . . . . . . . . . . . . . . . . . . . . . . . . . 42

3. Evidence for mid-holocene changes and human impact from floodplain deposits, colluvia and soils . . . . 54

3.1. Floodplain deposits. . . . . . . . . . . . . . . . . . . . . . . . . . . . . . . 54

3.2. Colluvia and soils . . . . . . . . . . . . . . . . . . . . . . . . . . 59

4. Lacustrine sediments, bogs and speleothems as archives for human and non-human induced environmental

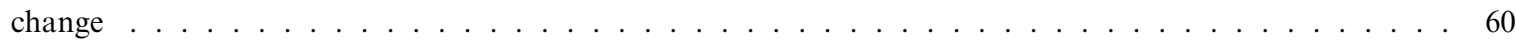

4.1. Climate . . . . . . . . . . . . . . . . . . . . . . . . 60

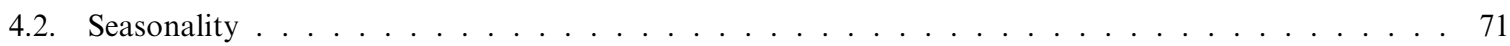

*Corresponding author.

E-mail address: j.wunderlich@em.uni-frankfurt.de (J. Wunderlich). 


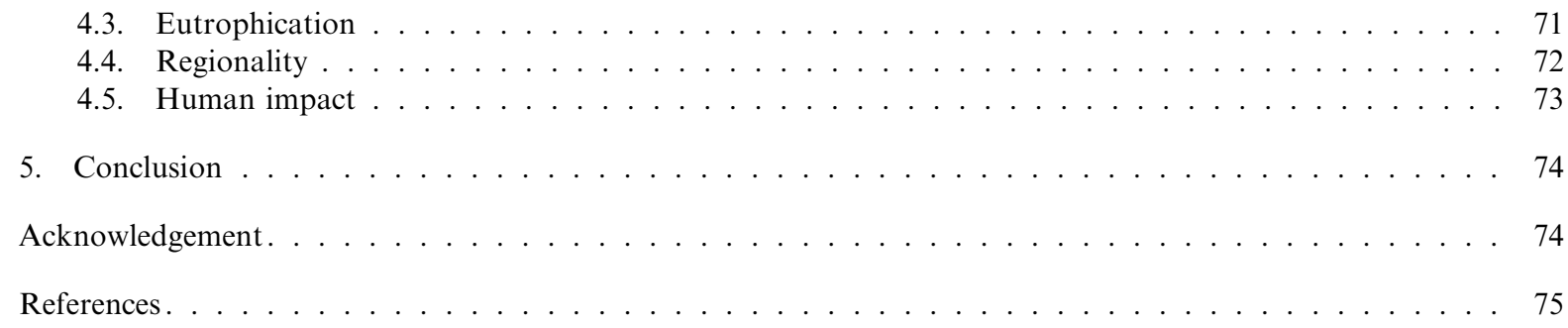

\section{Introduction}

Environmental changes are not only driven by a variety of natural forces but also by human impact. The interaction of both forces induces complex processes with profound effects on the environmental system. The course of environmental change can be reconstructed from natural archives, e.g. lake sediments, fluvial sediments, colluvia and soils, speleothems, peat and coastal sediments. However, it is difficult to distinguish to what extent natural, as opposed to human forcing, is responsible for the observed changes. The priority programme "Changes of the Geo-Biosphere" was established to clarify such matters (Litt, 2002). Time slice II, i.e. the interval ca $9000-5500$ cal BP, focusses on the onset of farming in central Europe, which is associated with the Neolithic Bandkeramik culture, at ca 7500 cal BP. Placing the focus on this aspect is entirely appropriate in that the introduction of farming brought with it for the first time the possibility of substantial human impact on the natural environment.

When the research programme was launched, time slice II, coinciding with the Atlantic period, was regarded as the period of climatic optimum but with little variability from the viewpoint of climate and other natural developments. However, anthropogenic activities such as settlement and agriculture, along with domestication of plants and animals, occurred during this time in central Europe, and various cultural periods have been distinguished within this time slice on the basis of archaeological findings. Furthermore, palaeobotanical and faunal analyses indicate that land-use and settlement practices varied in time and space. Even if these first human activities were less pronounced than during later phases, which experienced increased population and better technology, the potential for impact on the natural environment was still great. It was one of the aims of the priority programme to identify these effects and to distinguish between natural and human causes by using refined research methods to investigate appropriate archives from different landscape units (Fig. 1). The investigated archives, mentioned above, provide different tools to identify the style, intensity, and causes of environmental changes at different temporal resolutions. Comparison of the results allows the complex processes and interactions within the environment, which characterised this phase, to be identified.

\section{First human impact as reflected in pollen records from different regions in Germany}

The first substantial human impact on natural ecosystems resulted from the Neolithic way of life. The principal features of the Neolithic economy were arable and pastural farming, and these activities have left a distinct imprint on the European landscape. Indeed, the present-day landscape cannot be understood without taking into account the enormous impact agriculture has had on the shaping of Europe ever since. An important part of our research within time slice II was to pinpoint how and when farming began in our region.

As cultivated plants, e.g. cereals, require open areas that are more or less devoid of trees, clearance in the until then dense forests was an a priori requirement for arable farming. This transition from closed woodland to open, or at least partially open landscape is readily detectable in the palaeobotanical record.

\subsection{Settlement history}

Before considering Neolithic impact on vegetation, we present a short overview of early farming communities in Germany, their temporal and spatial distribution, their settlement patterns and, last but not least, their economy (subdivision, names and chronology of the Neolithic after Lüning (1996); archaeological chronology is in calendar years BC as generally used in archaeological literature).

At the beginning of the Holocene period, Europe was already inhabited by Mesolithic hunters and gatherers who lived in small groups, mainly along lakes and rivers and in coastal areas. The Early Mesolithic, i.e. from the Preboreal and early Boreal, is well known from many archaeological finds. During the Late Boreal and Early Atlantic periods the number of inland archaeological sites decreases, which contrasts with the coastal areas of the North Sea and the Baltic Sea, where highly developed Mesolithic societies flourished. 


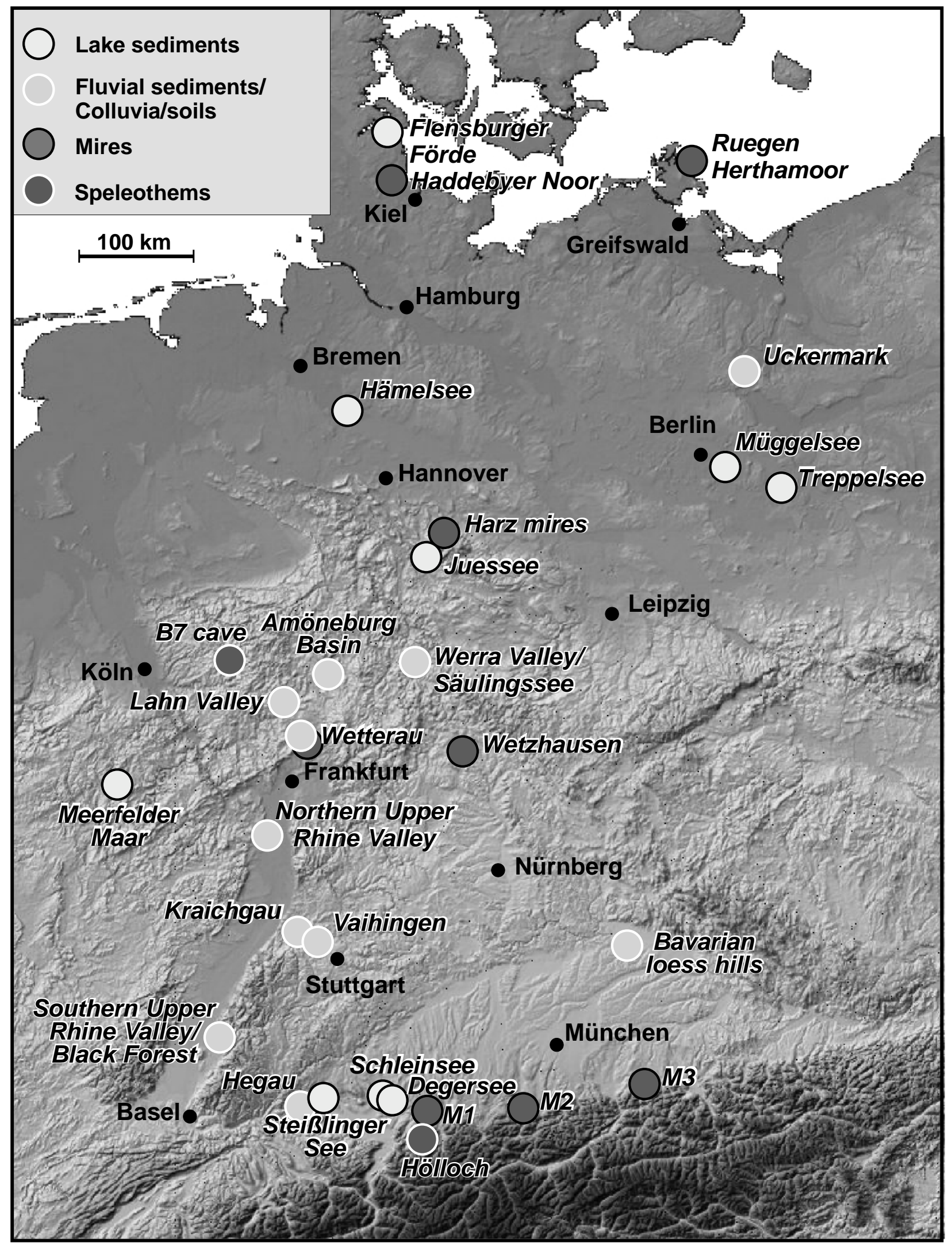

Fig. 1. Map of the study areas showing the location of the various archives. 
The first farmers of the Early Neolithic Linear Bandkeramik culture reached Germany about 5500 cal BC. They settled on loess areas between Hungary in the east, the Rhine in the west, the Danube (Donau) in the south and the loess belt near the present-day city of Hannover in the north. A second wave of expansion followed approximately two centuries later, during which the Bandkeramik farmers settled in almost every loess landscape north of the Alps. The northern boundary of distribution reached the Baltic Sea near the mouth of the river Oder, following a line through Hannover-Soest - Maastricht - Dunkirk, reaching the English Channel and Normandy in the west and extending eastwards as far as the river Dnjepr in Russia (Lüning, 1988). The farmers of the Linear Bandkeramik lived in large long-houses that occurred as isolated houses or in small groups along brooklets and small rivers (Lüning, 1997). The single family farms were economically self-sufficient, but finds such as amphibolite adzes from Czechoslovakia or Sphondylus shells from the Black Sea, show that networks of longdistance contacts existed within these society (Lüning, 2000, p. 15).

These peoples were full-time farmers. Hunting was initially important but very soon played a negligible role, with the exception of areas in the most southern part of Germany. The Bandkeramik farmers cultivated the cereals einkorn (Triticum monococcum), emmer (T. dicoccum) and barley (Hordeum vulgare) (emmer was generally the most important), the legumes pea (Pisum sativum) and lentil (Lens culinaris), and the oil plants poppy (Papaver setigerum) and linseed (Linum usitatissimum) (Willerding, 1980). The arable system of the Bandkeramik was not swidden cultivation as has been frequently assumed in the older literature. The farmers of the Bandkeramik grew their crops on permanent fields near their houses, and usually without fallow phases (Knörzer, 1986). The houses were used for only 20-25 years, but the succeeding houses were built on almost the same spot, which supported the idea that the fields remained fixed (Stehli, 1989). Moreover, there is evidence that the settlements and fields were surrounded by permanent hedges (Groenman-van Waateringe, 1971; Castelletti and Stäuble, 1997). The arable system was seemingly very stable and successful because hardly any change is noticeable during the five centuries of Bandkeramik culture (Knörzer, 1986). Cattle was the main domestic animal, but sheep, goats and pigs were also kept (Uerpmann, unpublished data). The animals grazed in the woodlands, the only available pastureland in those days. During the summer the animals were probably kept in more distant upland areas like the German Highlands, where the better grazing possibilities were exploited (Kalis and Zimmermann, 1988; Kubitz, 2000).
The Earliest Bandkeramik farmers constituted only a sparse population and grew emmer, einkorn and to some extent barley or millet (Kreuz, 1990). Cattle was the most important domestic animal and hunting was locally still important. The more densely populated Later Bandkeramik (ca 360000 people within former Western Germany; Lüning and Kalis, 1992), shows somewhat greater regional variability in both crops and animals. Willerding (1980) and Lüning (2000, Abb. 13) have mapped the crop distribution patterns.

Outside the loess landscape, in the greater part of Europe, people were still practising a life of hunting and gathering. Direct influence of the Neolithic culture on its Mesolithic neighbours is barely noticeable, with the possible exception of the La-Hoguette and the Limburg groups (Lüning et al., 1989) who lived to the southwest and west of the Bandkeramik culture respectively. They produced pottery and most probably practised animal husbandry to some degree. Finds of potsherds within Bandkeramik settlements show that contacts and exchange of goods took place between these groups (Lüning et al., 1989). The La-Hoguette group, however were not farmers, but seem to have continued to live according to Mesolithic practises (Kalis et al., 2001; Strien and Tilmann, 2001).

Because of the variability of the atmospheric ${ }^{14} \mathrm{C}$ content, the chronology of the Bandkeramik, which relies mainly on ${ }^{14} \mathrm{C}$ dating, is rather imprecise. The ${ }^{14} \mathrm{C}$ curve in the interval 6400-6000 BP has many "wiggles" so that the age range of calibrated ${ }^{14} \mathrm{C}$ dates from this interval, which is critical from the viewpoint of dating the Bandkeramik, is rather large (Weninger et al., 2001, Fig. 2). The discovery of a 14-m-deep well constructed from oak wood at the Bandkeramik settlement of Kückhoven (Weiner, 1992) provided well-preserved wood for dendrochronological dating (Schmidt et al., 1998). For the first time a phase of the ceramic chronology could be fixed, which enabled the end of the Bandkeramik culture to be dated to ca $5000 \mathrm{BC}$ (6950 cal BP). The beginnings and successive phases are still to be dated in detail.

The so-called Middle Neolithic is regarded as beginning at $5000 \mathrm{BC}(6950$ cal BP). By that time, northwestern Europe was no longer inhabited by one single culture, extending from the Dnjepr in Russia to the English Channel; instead there was now a pronounced regional differentiation of Neolithic cultures. At the household level also another way of life had emerged. The isolated farm houses were no longer the selfsufficient nucleus of society. Small hamlets emerged, consisting of several large farmhouses which were probably inhabited by more than one family. The number of settlements was smaller but they remained in use over longer periods (Lüning, 1982). The architecture of the houses was more diverse, possibly reflecting social differences. Large constructions for cult 
purposes express growing communal elements within Middle Neolithic society (Lüning, 2000). These newly established social structures seem to have been a more effective means to explore and open-up new land. This is seen in the extension of farming onto other soil types and even to other regions. Newly claimed areas included those between the loess landscapes, the pre-Alpine area (Alpenvorland) and several areas with fertile soils in the lowlands of northern Germany. Even the huntergatherer societies that still occupied the greater part of Northern Germany now showed Neolithic elements originating from the Middle Neolithic. The Swifterbant culture, situated between the North Sea and the river Elbe, and the Ertebølle culture from east of the Elbe and southern Scandinavia, both adopted the use and production of pottery (Raemaekers, 1999 resp. Schwabedissen, 1980) and animal husbandry (Hartz et al., 2000).

The Middle Neolithic began with the Hinkelstein group in southern Germany, the Großgartach group in southwestern Germany and the Stichbandkeramik culture in eastern Germany. At ca 4700 BC (6650 cal BP) the Rössen culture developed, which is probably the best known Middle Neolithic culture. The Middle Neolithic came to an end at ca 4300 BC (6250 cal BP) with the Bischheim and Münchshofen groups.

Agriculture was the economic base of Middle Neolithic society. Einkorn (Triticum monococcum) and emmer ( $T$. dicoccum) were the most important cultivated plants, but the proportions of free-threshing barley (Hordeum vulgare) were increasing, especially in Lower Bavaria (Niederbayern) and Saxony (Sachsen). The overall impression of continuity in arable farming from the Early to the Middle Neolithic is corroborated by the almost identical spectrum of arable weeds, showing that seed-times, methods of tillage, harvesting, crop processing, etc., remained relatively constant from the Early Bandkeramik onwards. However, the introduction of new, cultivated plants such as barley and the edaphically more demanding bread-wheat (Triticum aestivum) and a different spectrum of charcoal remains, which suggests that the fields and settlements were no longer surrounded by hedges, indicate that the arable farming economy was not identical to that of the Early Neolithic settlers. Regarding animal husbandry, there was little change. Cattle were still the most important domesticate. On the basis of age at slaughter, they were probably kept as dairy cows (Glass, 1991) but they also remained the most important source of meat, because, apart from certain areas in southern Germany, hunting played only a minor role.

At ca 4400 BC (6350 cal BP) the Younger Neolithic (Jungneolithikum) began. In archaeology, this period is commonly regarded as a continuation of the Middle Neolithic and is characterised by a range of only regionally important culture groups ("Aichbühl" around Lake Constance, "Schwieberdingen" followed by "Schussenried" in Neckarland, and "Münchshofen" followed by "Altheim" in Niederbayern. In the Paris basin the Michelsberg culture developed and expanded into south-western Germany. The eastern part of central Germany was occupied by the Gatersleben group). In the lowlands of northern Germany the Mesolithic tradition persisted in the Swifterbant and Ertebølle cultures. Nevertheless, a further Neolithic element penetrated into these cultures at ca $4200 \mathrm{BC}(6150 \mathrm{cal}$ $\mathrm{BP}$ ), namely the cultivation of the cereals emmer and barley (Swifterbant: Brinkkemper et al., 1999; Bakker, 2002; Ertebølle: Kalis and Meurers-Balke, 1998). From 4200 BC (6150 cal BP), this development gradually led to Neolithisation in eastern Holstein (Hartz et al., 2000). The appearance of the Funnel Beaker culture signals a new development in Neolithic society which became at 3500 BC (5450 cal BP) the dominant culture of the Late Neolithic in northern Germany, Poland and Scandinavia. (Hoika, 1987, 2000).

New developments characterise Younger Neolithic arable farming. For instance the introduction of the plough; one cannot rule out the possibility that ploughing had been practised earlier, but the oldest known plough marks date from the beginning of the 4th millennium BC (Tegtmeier, 1993). Compared with the Middle Neolithic, the spectrum of cultivated plants and the relative abundances of the various crops also changed drastically. An overall view of arable farming in the Younger Neolithic is beyond the scope of the present review, as each region appears to have its own distinctive features. Emmer, einkorn, free-threshing barley and wheat were grown in all regions but in differing proportions. In the pre-Alpine area between Zürichsee and Federsee free-threshing wheat, i.e. the Mediterranean species Triticum durum was the main crop (Maier, 1996, 2002). Further east, emmer and einkorn dominated (Küster, 1991). This increased diversity appears to have brought with it positive consequences for the spread of agriculture because, by the end of the Younger Neolithic i.e. by ca 3400 BC (5350 cal BP), arable farming was established in all regions of central Europe. Animal husbandry continued to be based on cattle, but within the Michelsberg culture pig assumed importance. On the other hand sheep and goat remained unimportant and hunting was insignificant, except in several pre-Alpine areas.

\subsection{Palynological reflection of early farming activities}

At present, the central European landscape is more or less entirely determined by human activity. Various forms of exploitation are associated with specific vegetation types such as arable weeds communities, meadows, heath, woodland, etc. The plants that 
constitute these communities produce vast amounts of pollen annually. As a consequence, the vegetation is reflected by its pollen production which in turn can be studied by pollen analysis.

The most obvious way to demonstrate Neolithic impact is by excavating sites where the farmers lived, kept their animals, prepared their food, etc. Here one can expect to find remains derived from crop procession, food of humans, fodder for domesticated animals and artefacts that give insight into all aspects of daily life. Although at most sites only charred plant remains are left, there are exceptions where also uncharred organic material occurs in good condition and so provides further opportunities for the reconstruction of human activity and the palaeoenvironment generally (Schlichtherle, 1991). However, such 'on-site' evidence were not the subject of research in the present priority programme. Rather, the aim was to investigate human impact at a broader landscape level and, in particular, to make reconstructions based on detailed pollen profiles derived from lakes and peat bogs. The principles underlying the interpretation of the various pollen components in a typical pollen profile are now considered.

\subsubsection{Non-arboreal pollen component and, in particular, cultural indicators}

AP/NAP ratio. The study of present-day surface pollen samples shows to what extent different vegetation types can be palynologically recognised. Such pollen/ vegetation studies illustrate that the largest contrast occurs between woodland on the one hand and treeless vegetation on the other. A critical inspection shows that the contrast is heavily biased by the broad spectrum of grassland plants, which characterise the present landscape (Gaillard et al., 1998). Comparable studies in areas with woodland and arable fields but without extensive grassland show that the contrast in pollen spectra between woodland and treeless vegetation is not that obvious (Hicks, 1998). The conclusion is that grassland (in the broadest sense) is the plant formation which, in pollen diagrams, best reflects the presence of man in the landscape of central Europe (especially in the $\mathrm{AP} / \mathrm{NAP}$ ratio). In the context of the Holocene as a whole, however, man-made grassland is a rather recent phenomenon. Intensive woodland grazing can admittedly lead to treeless vegetation, but plant species are grazed selectively by the animals based on the taste of the particular species. A park landscape with shrubs rather than purely open grassland results (Pott and Hüppe, 1991). Maintenance of grassland is distinctly favoured by mowing on a regular basis and preferably once a year. This in turn necessitates appropriate tools for mowing. It is therefore no coincidence that the development of man-made grassland vegetation is associated with the Early Iron Age (Körber-Grohne,
1990; Behre and Jacomet, 1991) with possibly some early examples in the Bronze Age (Rösch, 1993; Stobbe, 1996).

From a palynological point of view, human impact on the landscape is most readily detectable from the time that synanthropic grasslands first existed, i.e. from the Iron Age (and possibly the Late Bronze Age) onwards. This does not necesserily mean that, prior to this, there were fewer inhabitants or that human impact was less. It simply means that the impact is not as readily detectable in the pollen analytical data. As a consequence, the commonly used AP/NAP may not be the most appropriate for visualizing human impact before the Late Bronze Age. Many authors conclude from the low amounts of NAP in their pollen diagrams that human impact was negligable or absent during the Neolithic, though this view is often contradicted by archaeologists on the basis of large-scale excavations in the same area. This was also the case within the present priority programme. Although archaeologists have no doubt about the presence of man near the studied lakes, in several instances, pollen diagrams from lake deposits show very low NAP-percentages during this time slice despite incontrovertible archaeological evidence for a substantial human presence. This makes further reflections on this archaeo-palynological paradox appropriate because there are, besides the AP/NAP ratio, other palynological indicators of farming activity and its impact on the natural environment.

Cultivated plants. The most certain evidence of arable farming in pollen diagrams is the pollen of cultivated plants. The pollen of cereals, pea, lentil, linseed and poppy have sufficient morphological features to confidenly enable identification (i.e. Beug, 1961; Kalis, 1980; Punt and Den Breejen, 1981; Faegri and Iversen, 1989). Unfortunately, most cultivated plants are cleistogamic (self-pollinating) and so do not readily emit pollen into the atmosphere. Hence they are largely invisible in the regional pollen rain. This is also the case with Neolithic cereals, where the pollen remains within the glumes. Fortunately, Neolithic people were interested in the grain rather than the glumes, so that the cereals were threshed, the grains dehusked and the pollen liberated into the atmosphere. Furthermore, the products of threshing were winnowed which again favoured pollen dispersal. The size of the cereal pollen curve is therefore related to the proportion of cereal processed for human consumption rather than the amount of cereals cultivated or the location of the fields vis-a-vis the sampling site. Incidentally, cereal-type pollen have been recorded throughout the entire early Holocene. Non-cultivated grass species of the genera Elymus and Hordelymus also produce cereal-type pollen (Hordeum type, Beug, 1961). Such plants occur today on sand dunes along sea shores or in some rare types of forest on damp, fertile soils. Scattered finds of pollen of the Hordeum type or 
Cerealia indet. in pollen spectra without further indications of human presence have to be ascribed to these wild grass species (O'Connell, 1987; Schweizer, 2001). However, regular finds of Cerealia indet. pollen and all finds of Triticum-type pollen (ascribable exclusively to cultivated wheat species; Beug, 1961) are invariably younger than $5500 \mathrm{BC}$ and indicate cereal growing. Although no direct relation between pollen percentages and the extent of cereal cultivation can be deduced, the pollen of cereals remains the best indicator of arable farming.

Weeds and ruderals. At least one characteristic weed plant community occurred in cereal fields on loess soils during the whole of the Early and Middle Neolithic i.e. the Bromo-Lapsanetum praehistoricum (Knörzer, 1971). During the Younger Neolithic in the pre-Alpine region Jacomet et al. (1989) found characteristic weeds for flax fields, and it is likely that other crops had also their own characteristic weed communities. Because most weed species, like cultivated plants, originate from treeless vegetation outside central Europe (often from steppes), they are confined to arable habitats and are therefore, in addition to the crop plants, also reliable indicators of arable farming. Unfortunately, this does not make them always usable as cultural indicators in pollen diagrams from the Neolithic. Most of the presentday weed species had not yet entered Central Europe during the Neolithic (Behre, 1981; Knörzer, 1988). The greater proportion of weeds already present were cleistogamic or zoogamic and therefore poorly represented in Neolithic pollen records. Furthermore, the anemogamic plants in the Neolithic weed assemblages have pollen that is not readily identifiable to specific level. Often, they can only be assigned to indigenous families such as Poaceae and Chenopodiaceae or to the genus Rumex. With regard to these groups, the pollen of weeds cannot be distinguished from that of species already present in the natural vegetation. Thus the vegetation of arable fields during the Neolithic remains, to a large extent, indistinguishable in the pollen record (Lüning and Kalis, 1992). The results of the pollen analyses in the present priority programme corroborate this.

Forest clearings. The extent of arable cultivation also regards detection in the palynological record. Although very few Neolithic fields could be excavated in situ, one can, in thoroughly excavated landscapes, reflect on their range. Several estimates of the extent of cultivation have been published, especially for the Early Neolithic. Knörzer (1986) suggested that during the Early and Middle Neolithic, arable land on loess soils was permanently used without fallow phases. The cereal production of 1 ha of such fields can feed three persons. Based on large-scale excavations near Aachen, a population density of 17 inhabitants per $\mathrm{km}^{2}$ has been suggested for the period of Bandkeramik settle- ment in that site (Lüning, 1988). To feed this population ca 5-6 ha arable land per $\mathrm{km}^{2}$ was needed. The question arises as to whether such a relatively small area would be visible in the pollen diagrams. It is assumed that the fields were situated close to each other. But even a large arable area in a forested landscape seems difficult to detect. In surface pollen samples from a Finnish woodland, Hicks (1998) could not detect a 2500-ha area of arable fields at a distance of only $250 \mathrm{~m}$. This empirically observed fact corroborates the computer simulations of Sugita (1998), which show that disturbances of 4100 and 2500 ha at only $100 \mathrm{~m}$ away from a lake do not create detectable decreases in AP pollen loading of any of the taxa. Only a disturbance of 100-ha extent, when it occurs at the lake shore, generates more than $20 \%$ decline of AP pollen loadings and shifts the pollen percentage representation. Thus the poor reflection of the Early and Middle Neolithic arable cultivation areas in the pollen diagrams from 'off-site' lake deposits is quite understandable. From this point of view, the results from the two sites presented here in which Early Neolithic arable farming is clearly represented, assume added interest. It implies that the sites in question, i.e. peat bogs in the Wetterau (Fig. 4, Schweizer, 2001) and Grabfeld (Fig. 7, Reichart, in preparation), which are situated in river valleys, were bordered by Bandkeramik fields and that these extended over at least 100 ha near these sites. A detailed archaeological field survey of the Wetterau near the pollen site (Schade, 2001) has shown that the Bandkeramik settlement pattern meets this requirement.

The lake pollen diagrams from the present priority programme inevitably show that 'off-site' pollen analysis is not an appropriate tool to illustrate the intensity and extent of Early Neolithic arable farming. This only changes when:

1. the extent of arable farm land increases greatly,

2. the diversity of weed species increases, especially wind-pollinated species,

3. the arable system is changed, for instance from permanent tillage to swidden cultivation or other types of agriculture.

Several authors have dealt with these aspects with regard to Late Neolithic arable farming (cf. Rösch, 1990), but that period is beyond the scope of this review.

\subsubsection{Arboreal pollen component}

The potential of palynology for showing plant communities with high amounts of wind-pollinated plant species such as forest, shrubs, tall herb communities and grasslands ensures that their composition and their succession processes are well documented in the pollen diagrams. 
Primary forest. The general view has been that during the postglacial climatic optimum the vegetation cover of Europe developed to give natural climax vegetation. It has also been commonly held that both Mesolithic and Neolithic man had little overall effect on the natural vegetation. This view requires further consideration, at least for the Early and Middle Neolithic, as we shall discuss below. Even Mesolithic cultures had an impact on the natural vegetation insofar as they may have favoured Early Postglacial expansion of hazel (see Bos and Urz, 2002). Therefore, vegetation was at its most natural in periods with the fewest traces of human occupation, which in the case of Central Europe, appears to be the Late Mesolithic, i.e. the Early Atlantic period.

During the Early Atlantic period, Europe was covered with forest. Undisturbed forest development favours late-successional tree species such as Carpinus betulus, Fagus sylvatica, Tilia cordata and Ulmus laevis in lowlands and lower uplands, and F. sylvatica, Abies alba and Ulmus glabra in the highlands. During the Early Atlantic period, however, the most important present-day late-successional species Carpinus betulus and Fagus sylvatica had not yet entered Central Europe. Instead, the primary forest was dominated by Tilia cordata on fertile soils, Ulmus minor and U. laevis in river valleys and along brooks, Alnus glutinosa on mires, and $U$. glabra in the highlands (Pott, 2000). Oak species played a subordinate role on fertile soils, but were important in river valleys, highlands and in forests on poor soils. During the Early Atlantic period, regions with a low annual precipitation were covered with pine (Pinus sylvestris), rather than deciduous forests.

Regional variation. Within the extensive research area of the present priority programme, there is a large diversity of landscapes which is reflected in both the present and the former vegetation patterns. Zonal vegetation within Germany is mainly differentiated along two gradients, namely a vertical gradient correlated with height above sea-level, and a horizontal gradient that reflects degrees of oceanity/continentality. Edaphic conditions also play a major role. In this study, the vertical gradient is not of major importance since the selected sites are from below $350 \mathrm{~m}$ a.s.l. (with the exception of Degersee). Plant response to this diversity in the Early Atlantic period is well mirrored in the pollen diagrams. Coarsely put, the following regions can be distinguished from south to north:

Pre-Alpine moraine landscape of the Würm glaciation. This area is hilly to mountainous with a mosaic of fertile, poor and wet soils. In the Early Atlantic period it was covered with oak-lime woods in the fertile uplands, oak-ash-elm woods in the river valleys and elm woods at higher altitudes of the montane vegetation belt. Alder was rare (Hegau-Steißlinger See, Fig. 2; Allgäu-Degersee, Fig. 3)
In the loess areas in southern Germany characterised by continental conditions, for instance in Niederbayern (Peters, in preparation) and in the southern Upper Rhine Valley (profil Wasenweiler Ried, Friedmann, 1999), pine constitutes the Early Atlantic climax vegetation (not illustrated by a pollen diagram).

Continental loess landscapes within the highland zone. These are hilly areas with fertile soils, dominated by pine woods on the upland soils and some oak-elm woods in the river valleys. Alder carr had not yet developed (Magdeburger Börde-Müller, 1953; Litt, 1992a,b; Wetterau-Salzwiese, Fig. 4).

The mountainous and sub-mountainous vegetation belts of the German Highlands with their moist climate were covered with oak-lime woods at lower altitudes and oak-elm woods at higher altitudes (WerraFulda highlands-Säulingssee, Fig. 6; UnterfrankenWetzhausen, Fig. 7; Eifel highlands-Meerfelder Maar, Fig. 5).

Oceanic loess landscapes within the highland zone. These are hilly areas with fertile, loess soils, which were dominated by lime on the upland soils, and elm in the river valleys, along brooks and on the damp, lower fringe of slopes. Mires were rare and hence few alder carrs existed (Untereichsfeld-Jues-See, Fig. 8).

The older morainic landscape of the northern German Lowlands. This area was covered by the ice during the penultimate (Saale) but not during the last (Weichselian) glaciation. It is a flat, undulating area with poor, sandy soils (Geest) and often high water tables. Alder carr dominated on wet soils, while in the upland soils lime and oak flourished and elm and oak where soils were more fertile (Hämelsee, Fig. 9).

The younger morainic landscape along the Baltic Sea. This is a hilly area with fertile soils and many lakes and mires. Lime woods dominated the uplands, elm woods grew along rivers, brooks and at the lower fringe of hills, and alder carr was common on mires (Rügen-Herthamoor, Fig. 12; Schleswig-Holstein-Haddebyer Noor, Fig. 11; Flensburger Förde, Fig. 10).

It is noteworthy that the distribution of pine reached remarkably further westward than today, which suggests that the gradient from oceanic to continental climate in Germany during the Early Atlantic differed from that of today. The distribution pattern of pine woods cannot be ascribed to a delayed spread of deciduous trees which, by now, had reached the river valleys of the dry loess landscapes. Elm was present in small quantities and lime and alder expanded at a later time, but not earlier than the Subboreal. This also points to a more continental precipitation regime during the Early Atlantic in southern and eastern Germany.

Secondary forest cycles. Woodland was the dominant plant formation during the Neolithic. Almost all activities of the Neolithic peoples had consequences for the vegetation and resulted in changes to its 
composition. The use of wood as fuel and building material, the creation of treeless areas for arable fields and settlements on the one hand, and woodland pasture including leaf fodder for animals on the other hand, resulted in all types of secondary woodland, shrub formations and tall herb communities. This is clearly reflected in the regional pollen rain. In 1941, Johs. Iversen was the first palynologist who recognised this. Against generally accepted view of his time, he postulated that the disappearance of primary forest in Denmark during the transition from the Atlantic to the Subboreal was not caused by climatic change, but rather by farming activities of the Funnel Beaker culture. The expansion of arable activity and animal husbandry destroyed the climax elm and lime forests and caused the development of secondary woodland consisting merely of alder, birch and hazel, which characterised the Early Subboreal pollen spectra (Iversen, 1973). The correlation between the so-called "Iversen landnam" and the expansion of agriculture in Denmark is now commonly accepted and used in the interpretation of the pollen diagrams from Schleswig-Holstein (Dörfler, 2001). Iversen's ecological explanation of the palynological phenomena reflecting the natural regeneration processes in woodlands is also applicable to earlier phases of the Neolithic. Undisturbed forest development favours 'late-successional species' (after Berglund et al., 1991, p. 405) such as Fagus sylvatica, Tilia cordata and Ulmus spp., whereas forest disturbances lead to high proportions of 'early successional tree species' (Berglund, 1991) such as Alnus glutinosa, Betula pendula, B. pubescens, Corylus avellana and Fraxinus excelsior. These are indicators of the so-called secondary forest cycle, a part of the natural succession in which secondary forests regenerate in several stages towards primary forest. The early successional species also include oak and pine, although they are of intermediate status. Quercus robur, which grows best in secondary woodland is also found however in undisturbed forests on poorer soils. Pinus sylvestris, on the other hand, was the naturally dominant tree in the more arid parts of Germany during the Atlantic period (see Regional variation).

The above-mentioned tree species produce and emit so much pollen that they are clearly visible in the regional pollen rain. The succession of woodland vegetation, especially within the secondary forest cycles, is therefore the most visible palynological feature of early human impact (cf. Müller, 1962; Aaby, 1986; Ammann, 1988; Kalis, 1988).

Every forest clearing results in edge communities where forest regeneration starts again. The hedges of the Early Neolithic fields and settlements consisted more or less of the same species as found in woodland edges. Early successional species dominated the vegetation in abandoned fields and settlements and in any other abandoned treeless area. Consequently, high percentage representation of early successional species in pollen diagrams from the Atlantic period point to the existence of secondary forest. They are the indirect reflection of Early Neolithic arable farming that cannot otherwise be demonstrated directly by palynology.

Animal husbandry was another Neolithic activity which clearly affected woodland vegetation. In the absence of grassland, livestock were kept in the forest. This posed no insuperable problems to cattle and pigs, as they derived originally from wooded habitats. Present-day observations show that sheep and goats can also survive in such habitats. Woodland grazing, however has severe consequences for the forest itself. As seedlings and young trees are eaten, the forest's natural rejuvenation is hindered. Bark and twigs are bitten off, seriously affecting tree species such as lime and beech. Oak, on the other hand, was avoided by livestock because its bark and leaves are unpalatable. On the other hand, rooting by pigs has a positive effect on the germination of oak (Stobbe, 1996). In summary, grazing had a decided effect on the composition of the Atlantic woodlands. Early successional species were favoured as long as woodland pasture was maintained. With its dense shrub vegetation, secondary forest is more attractive for livestock than natural forest. It has a much higher biomass production, especially leaves and twigs which grows conveniently low for grazers during the early years. Furthermore, the tall herb vegetation is much more luxuriant than the sparse understorey of primary forest. Neolithic farmers may have acted to permanently maintain woodland in an early successional stage, as was probably done earlier on a smaller scale by Mesolithic peoples so as to attract game (see Bos and Urz, 2002). Iversen (1941) had already considered this when he claimed that the large-scale woodland fires, which characterise the beginning of the Subboreal in Denmark, were deliberate with a view to creating secondary forest as grazing for livestock.

The effects of forest clearance and woodland grazing on arable farming are reflected in the regional pollen rain. Cycles of forest regeneration are recognised in pollen diagrams from southern Germany (Müller, 1962) and from the Swiss Plateau (Ammann, 1989). The cycles begin with tall herbs, followed by the pioneer trees birch or alder, then ash and hazel, leading to the secondary forest where oak mainly dominates. The cycle than ends in the original forest type. Not every clearing leads to a complete succession. Firstly, the succession should not be interrupted by another clearance. Secondly, the rate and direction of forest succession depends largely on local edaphic conditions. The cycles are most visible in areas with fertile soils, because here forest regeneration is rapid. On poor soils, clearings can easily lead to irreversible degradation of the soil. In such cases, woodland needs much more time to regenerate, if at all. 
All three possibilities are reflected by examples in the present pollen diagrams. In the Salzwiese diagram from the Wetterau (Hessen) only one clearance is recorded, i.e. that one at ca $5500 \mathrm{BC}(7450$ cal BP) caused by the Early Neolithic Bandkeramik people (Fig. 4, above $224 \mathrm{~cm}$ ). Although numerous farming systems have succeeded each other from the Early Neolithic up to the present, the area was not abandoned and forest regeneration has not taken place in this fertile area after the first clearing 7450 years ago (Stobbe, 2000; Schweizer, 2001). On the other hand, some fine examples of secondary forest cycles are recorded in the other profiles. Examples are given in discussing the individual pollen diagrams.

Forest fires. Analyses of lake deposits and peat bogs reveal that fire played an increasing role in landscape management during the Neolithic. Since Lateglacial times, charcoal plant fragments are ubiquitous in many types of deposits in Germany including lacustrine, bog or eolian deposits. Not all fires are attributable to humans, especially when conifer woodlands are involved, as conifers may catch fire spontaneously. However, according to recent experiences in Germany (forest fires in northern Germany; experimental archaeology), sound, deciduous forest is almost fire-proof. Noticeable peaks of charcoal in pollen diagrams, ocurring after the establishment of the Atlantic deciduous forest types, may therefore be considered as possibly due to human activity. This is especially true when the charcoal is connected with secondary forest cycles. Such peaks, accompanied by secondary forest cycles, are reported from the Schleinsee (Clark et al., 1989) and the Degersee (Kleinmann et al., in preparation) from $6250 \mathrm{BC}(8200 \mathrm{cal} \mathrm{BP})$ onwards, at intervals of 200-300 years. Fire signals increasingly accompanied by the alga Bosmina longirostris, which points to eutrophication by fire, are found after 6900 BC (8850 cal BP). A surprisingly early example from the Early Mesolithic in the valley of the Lahn near Marburg (Hessen) is described by Bos and Urz (2002). Near an Early Mesolithic camp site on the levees of an oxbow lake of the river Lahn, lake sediments were examined for pollen and plant macroremains. Both the camp site and the deposits proved to be Early Boreal and the spectrum of macroremains showed plant species, indicating a high degree of nitrification caused by a local human presence (Urz, 2000). Besides the local vegetation, the regional vegetation is also reflected in the pollen diagram. It is clear that the vegetation around the camp was regularly and deliberately burnt so that the Early Boreal pine woods were temporarily replaced by tall herb vegetation, including Artemisia sp., Chenopodiaceae and even Plantago lanceolata, and hazel shrub. However, pine soon regained its former dominance. After the disturbance of the primary pine forest, the vegetation reacted with the development of fast growing vegetation to close the gap and restore the original forest. Tall herb vegetation was followed by secondary woodland and finally by the original woodland type. At least five cycles could be detected.

Fire and forest cycles with increased magnitude occur later in Schleinsee around $5450 \mathrm{BC}(7400 \mathrm{cal} \mathrm{BP}), 5250$ BC (7200 cal BP) and 5000 BC (6950 cal BP), contemporary with the Early Neolithic. Another feature indicating the burning of vegetation are the finds of pollen grains that have been subjected to substantial heating. Andersen (1988) first described the alterations in the morphology of pollen grains that had been exposed to fire. He connected the high number of such grains found in Neolithic pollen spectra in Denmark with the agricultural system of the Funnel Beaker culture. Here, fire was used to create pasture from the secondary forest. Such pollen grains also appear in pollen spectra from much earlier times. Schweizer (2001) found them in mire profiles in the Wetterau from the Late Mesolithic onwards, with increasing quantities in the Early Neolithic.

Elevated Betula representation is another indirect indicator of woodland fires. Betula pendula germinates extremely well in the ashes of newly burnt woodland, independently of the quality of the soil. Therefore it frequently dominates the first stage in woodland succession after burning (Dengler, 1935, p. 214). A high frequency of fires causes elevated Betula representation in regional pollen diagrams. Lower fire frequency, and thus cycles of longer duration, stimulates the development of hazel. High pollen concentrations of Betula and Corylus, in combination with a high content of charcoal dust in the regional pollen rain of the Younger Neolithic in southwestern Germany, led Rösch (1990) to postulate a 'slash and burn' agriculture for the entire Younger and Later Neolithic. However, Lechterbeck (2000) could not confirm the correlation of the high Betula and Corylus values with charcoal representation in the nearby Steißlinger See. Further research is required to clarify this.

\subsection{Regions (from south to north)}

Pre-Alpine moraine landscape of the Würm glaciation: western Lake Constance (Bodensee): Steißlinger See (Lechterbeck, 2000), Fig. 2; eastern Lake Constance: Degersee (Müller, in preparation), Fig. 3.

Steißlinger See lies in the pre-Alpine younger moraine landscape of the Hegau in Baden-Württemberg, ca $7 \mathrm{~km}$ north-west of Lake Constance. From the point of view of both archaeology and vegetation history, this is one of the best-known landscapes of southern Germany. Intensive archaeological research is conducted from the research station of Hemmenhofen (Schlichtherle, 1991). High-resolution pollen diagrams are available from Durchenbergried and Hornstaad (Rösch, 1990, 1993) which lie 4.5 and $12 \mathrm{~km}$, respectively south-east of 
Steißlinger See. The latter contains annually laminated sediments, enabling a precise chronology (Wolf-Brozio cited in Lechterbeck). Pollen analysis of the varved lacustrine deposits of the Steißlinger See (Lechterbeck, 2000) makes possible the long-awaited correlation between vegetation and settlement history. Unfortunately, the lamination does not reach the top of the lake sediments. The floating varve chronology has been fixed with the help of 14 AMS ${ }^{14} \mathrm{C}$ dates. This probably explains the difference of approximately one century between the estimated age and the archaeologists' chronology. Ages quoted below are based on this estimate.

At $5475 \mathrm{BC}(7425 \mathrm{cal} \mathrm{BP})$, there is a marked change in that the pollen curves of the late successional species
Tilia and Ulmus reach a minimum, whereas that of Corylus attains a pronounced maximum (Fig. 2). A secondary forest cycle of Alnus, Betula, Fraxinus and Quercus follows and at ca $5300 \mathrm{BC}(7250 \mathrm{cal} \mathrm{BP})$ also Tilia. Forest clearance in the 6th millennium BC as recorded in pollen diagrams is often connected with the Linear Bandkeramik culture. Indeed, early farmers settled in the Hegau, although archaeological evidence from within $8 \mathrm{~km}$ of the lake has yet to be found. According to the archaeological chronology, this first evidence of a farming presence is not earlier than ca 5300 BC. At 4900 BC (6850 cal BP), a decrease in Ulmus is connected with an increase of Quercus, Alnus and Fagus and the first appearance of Plantago major/media and Chenopodiaceae. This may be connected with

\section{STEISSLINGER SEE} Selected pollentypes

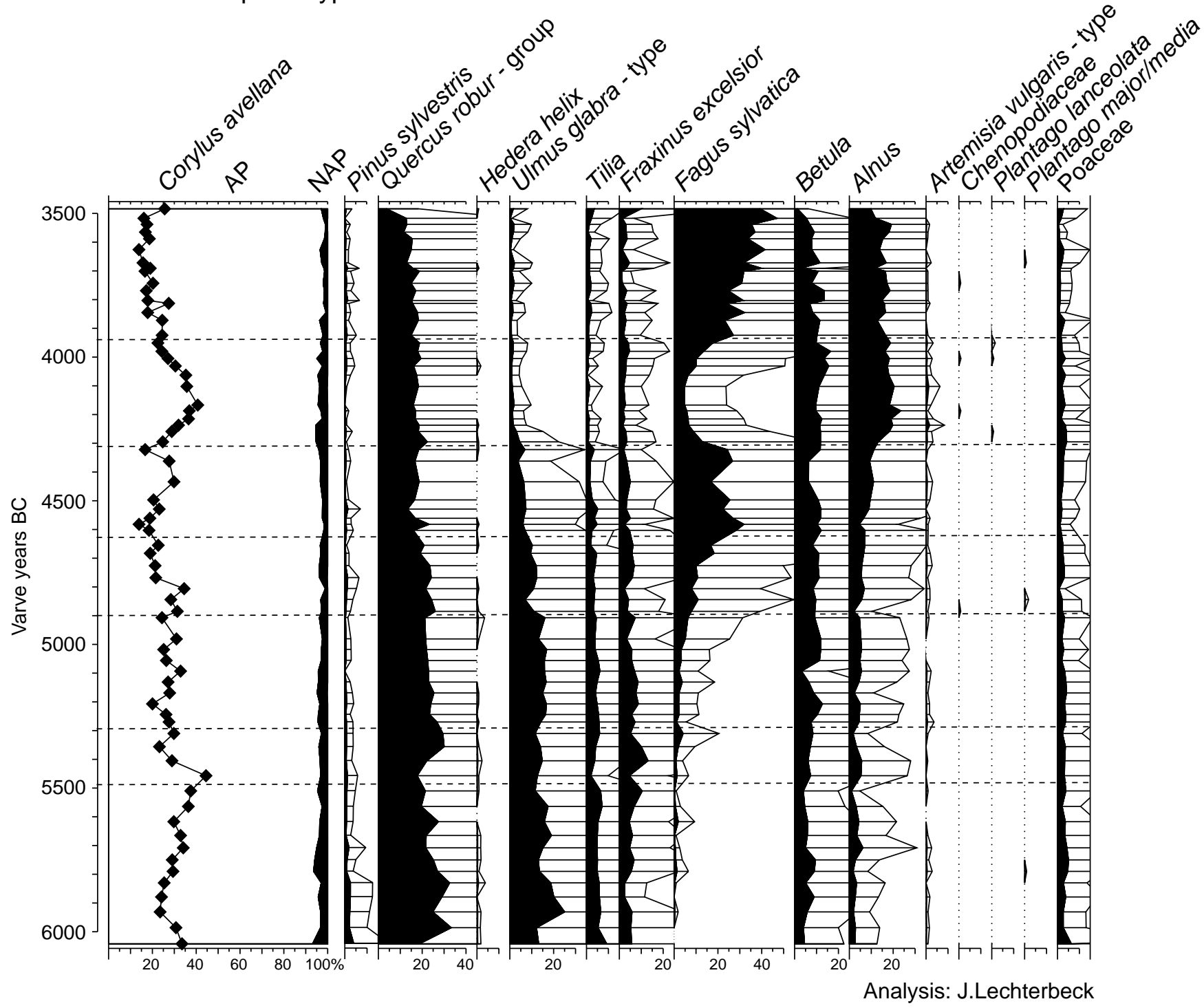

Fig. 2. Percentage pollen diagram from the Steißlinger See after data from J. Lechterbeck (rearranged and redrawn). 
Middle Neolithic human activity. Also the expansion of beech (Fagus sylvatica) is often connected with human impact on the natural (lime) forests (Pott, 2000). Whether it was deliberately introduced or behaved as an "oversized weed" (Bottema, 1988) remains unclear. After its establishment as a pioneer, beech behaves as a late-successional species and the high pollen values between 4600 and $4400 \mathrm{BC}$ seem to reflect woodland regeneration. At ca $4300 \mathrm{BC}(6450 \mathrm{cal} \mathrm{BP})$ all latesuccessional tree species decrease sharply and the curves for Alnus, Betula, Corylus and Quercus increase, indicating a strong human impact on the landscape. This feature is characteristic for all lowland pollen diagrams from southwest Germany and pre-Alpine Switzerland. Müller (1962) assumes, on the basis of the pollen percentage values, that at $6250 \mathrm{cal} \mathrm{BP}$ in the catchment area of the Schleinsee, the beech-, elm- and lime woodland had declined to less than $10 \%$ of its climatic potential as a result of clearances. The population which was responsible for this impact belonged to the Younger Neolithic Aichbühl group. Several authors have tried to explain these features. Rösch (1990, 1993) postulates a shifting cultivation with 'slash and burn'-like temporary clearings. This would explain the drastic reduction of natural forest vegetation. A whole landscape dominated by secondary forest is envisaged. Rösch assumes that woodland burning was practised to make way for arable farming. Maier in Dieckmann et al. (2002), however, proposed permanent arable farming, based on evidence from plant macroremains. High percentages of charcoal dust in the sediments indicate forest fires. If firing was not carried out to benefit arable farming, then the reason is, as yet, unclear. This intense human impact lasted until about 3950 BC (5900 cal BP). After forest regeneration of nearly four centuries, the next large impact begins with the Horgen culture at about 3400 BC.

The Degersee, east of Lake Constance, lies at an altitude of $478 \mathrm{~m}$, i.e. in the montane vegetation where precipitation is higher than near the Steißlinger See. The pollen diagram (Fig. 3) reflects this. Percentages of elm and ash, characteristic of Atlantic mountain forests are higher, whereas representation of the lowland species oak and lime is much lower than at Steißlinger See. The human impact record is also different. Until $5000 \mathrm{BC}$ (6950 BP varve age) all pollen curves reflect natural vegetation dynamics. The decline of elm beginning at $5000 \mathrm{BC}$ is probably caused by the expansion of beech in the elm forests of the montane vegetation belt and human impact is not detectable until $4450 \mathrm{BC}$ (6400 BP varve age). A slight decline of the curves for beech, lime and elm is associated with an increase in hazel, grasses and the first finds of cereal pollen which suggests arable farming by people of the Rössen culture. After a classical forest regeneration between 4300 and 4200 $\mathrm{BC}$ (6250 and 6150 BP varve age), a renewed forest clearance occurs between 4050 and $3800 \mathrm{BC}$, the latesuccessional species beech and lime reaching a minimum, birch hazel and alder containing a maximum. Archaeological evidence for a corresponding Younger Neolithic culture is yet to be found. After some forest regeneration, another remarkable forest clearance occurred at ca $3650 \mathrm{BC}$ that lasted about a century (PfynAltheim?). The pollen profiles from Steißlinger See and Degersee corroborate the archaeological evidence, which shows that the landscapes east and west of Lake Constance had quite different settlement histories, especially during the Younger Neolithic.

Continental loess landscapes within the highland zone: Hessen: Wetterau (Schweizer, 2001), Fig. 4. The Wetter$\mathrm{au}$ is an intra-montane basin between the highlands of the Rheinisches Schiefergebirge in the west and Vogelsberg in the east. Its sheltered position results in favourable climatic conditions. Combined with fertile loess soils, this makes the Wetterau one of the best agricultural areas of Germany. Arable farming was established here as early as $5500 \mathrm{BC}$ and has remained the most important human activity ever since. Along the river Wetter, a chain of mires have developed since the Early Holocene. The peat deposits facilitate palynological investigations. In contrast to the surrounding highlands where lime and elm woodland prevailed, the Early Atlantic vegetation was dominated by pine forest. This reflects the specific meso-climate of this basin in the rain shadow of the highlands. The arrival of Early Bandkeramik farmers is marked by a sharp decrease in pine and an increase in NAP. It is one of the very few pollen diagrams where the Early Neolithic forest clearings are reflected by an increase of NAP (the Luttersee in Untereichsfeld is another example; Beug, 1992). This can only be explained by the existence of extensive woodland clearings with arable fields beside the investigated peat deposits which is supported by the archaeological evidence (Schade, 2001). Preceeding the Early Neolithic, the pollen diagrams show an increase of Corylus from $5700 \mathrm{BC}$ onwards, which points to some kind of woodland clearing. Schweizer ascribes this to the activities of the Late Mesolithic La-Hoguette group. This group was living at the periphery of the Early Neolithic in northeastern France. There are hardly any changes in the pollen profile between the Early and Middle Neolithic. The Middle Neolithic was beyond the scope of Schweizer's study and therefore not analysed.

The western German highland zone: Eifel - Meerfelder Maar (Kubitz, 2000), Fig. 5. The Meerfelder Maar, a crater lake of a former volcano located in a side valley of the river Mosel, is situated at an altitude of $344 \mathrm{~m}$ a.s.1. in the Moseleifel, a part of the Eifel Highlands. From the Early Neolithic onwards, the Mosel valley itself was inhabited by farmers (Löhr, 1986). There is archaeological evidence for human presence in the vicinity of the Maar (Löhr, 1986; Nakoinz in Kubitz, 2000), 


\section{DEGERSEE}

\section{Selected pollentypes}

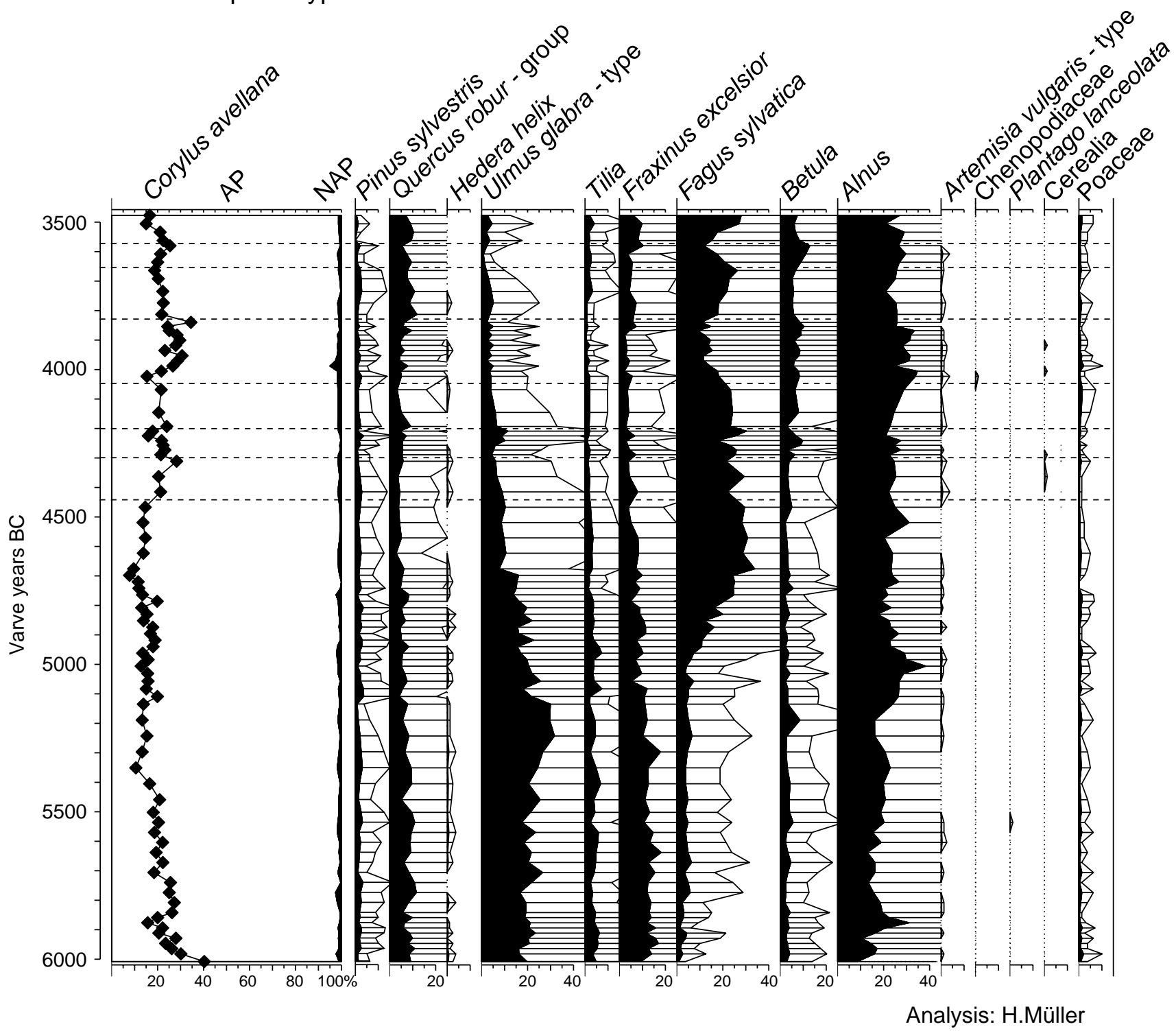

Fig. 3. Percentage pollen diagram from the Degersee after data from H. Müller (rearranged and redrawn).

though permanent settlements are lacking. The lake sediments are annually laminated, so that the pollen profile may have a precise and accurate chronology. The laminae or varves extend from the Early Boreal to the Middle Ages, but unfortunately not up to the present. Thus, the varve chronology is a floating chronology that is anchored with the help of ${ }^{14} \mathrm{C}$ dates Two chronologies have been made by C. Endres and A. Brauer (in Kubitz, 2000, p. 23); ages quoted below are based on the latter (Fig. 5).

A strong AP signal marks Early Neolithic impact. Percentage representation of late successional species fall sharply at $5500 \mathrm{BC}(7450 \mathrm{cal} \mathrm{BP})$, while Corylus and Fraxinus peak. A secondary forest succession with
Alnus, Betula and Quercus starts and within ca 100 years this gives way to lime-dominated woodland similar to that which existed prior to the disturbance. Kubitz (2000) ascribes this to the effects of woodland pasture by Early Neolithic farmers from the nearby Mosel valley. Another secondary forest cycle of 130 years is visible between 5320 and $5150 \mathrm{BC}(7270$ and $7100 \mathrm{cal} \mathrm{BP})$. Both cycles are ascribed to the Linear Bandkeramik culture, although they pre-date by approximately one century the corresponding phases of human activity as detected and dated by archaeologists. After a woodland regeneration phase during which Quercus values fall and Ulmus and Tilia increase, the reverse process began at 4950 BC (6900 cal BP) and lasted for 225 years. This 


\section{SALZWIESE (Wetterau/Hessen)}

Selected pollentypes

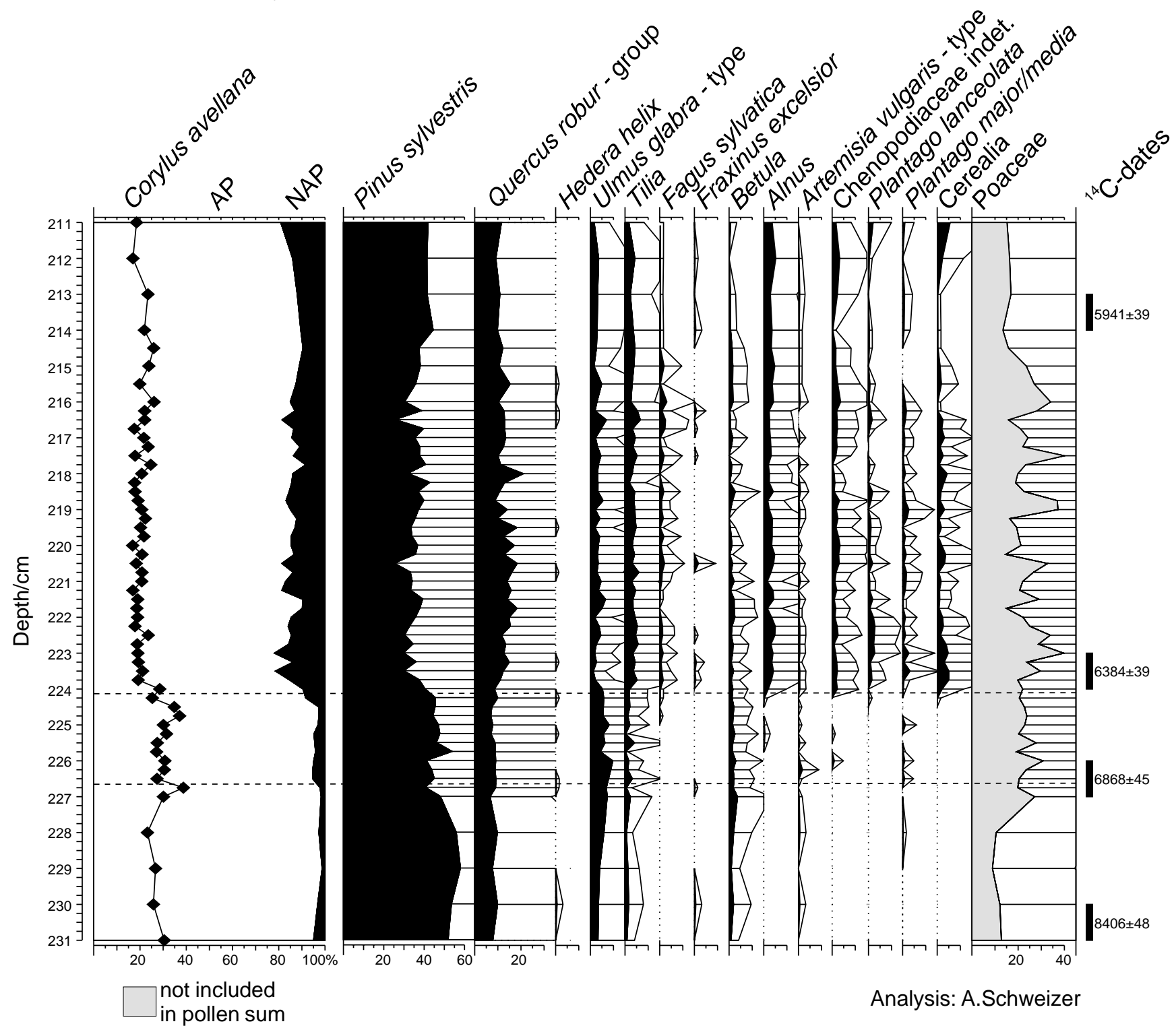

Fig. 4. Percentage pollen diagram from the Salzwiese after data from A. Schweizer (rearranged and redrawn).

corresponds to the Middle Neolithic, though the relevant cultural period i.e. Rössen, too dates to approximately one century later. Human impact near the lake also affected water quality. The alga, Pediastrum, is better represented, which indicates eutrophication, which in turn, has been linked to the pasture of livestock in the catchment area during the Middle Neolithic. After a short regeneration and decreasing Pediastrum values which began at 4500 BC (6450 cal BP), Ulmus values decline again, and Fraxinus and also Pediastrum increase, again pointing to nearby woodland pasture. This lasted 160 years and may be ascribed to the Bischheim culture.
The changes in AP representation during the Atlantic are rather slight in comparison to those recorded from 4220 BC (6170 cal BP) onwards. The pollen curves for Quercus, Ulmus, Fraxinus and Alnus decrease substantially, while Corylus greatly increases. The author ascribes this to large-scale clearances within the Eifel uplands. The Eifel was not only used for woodland pasture and hunting but, during the Younger Neolithic arable farmers of the Michelsberg culture settled in the uplands and had arable plots in woodland clearings. This is therefore another example of the use of the Eifel by people of the Michelsberg culture, as assumed by Kalis and Meurers-Balke (1997). After a maximum of 


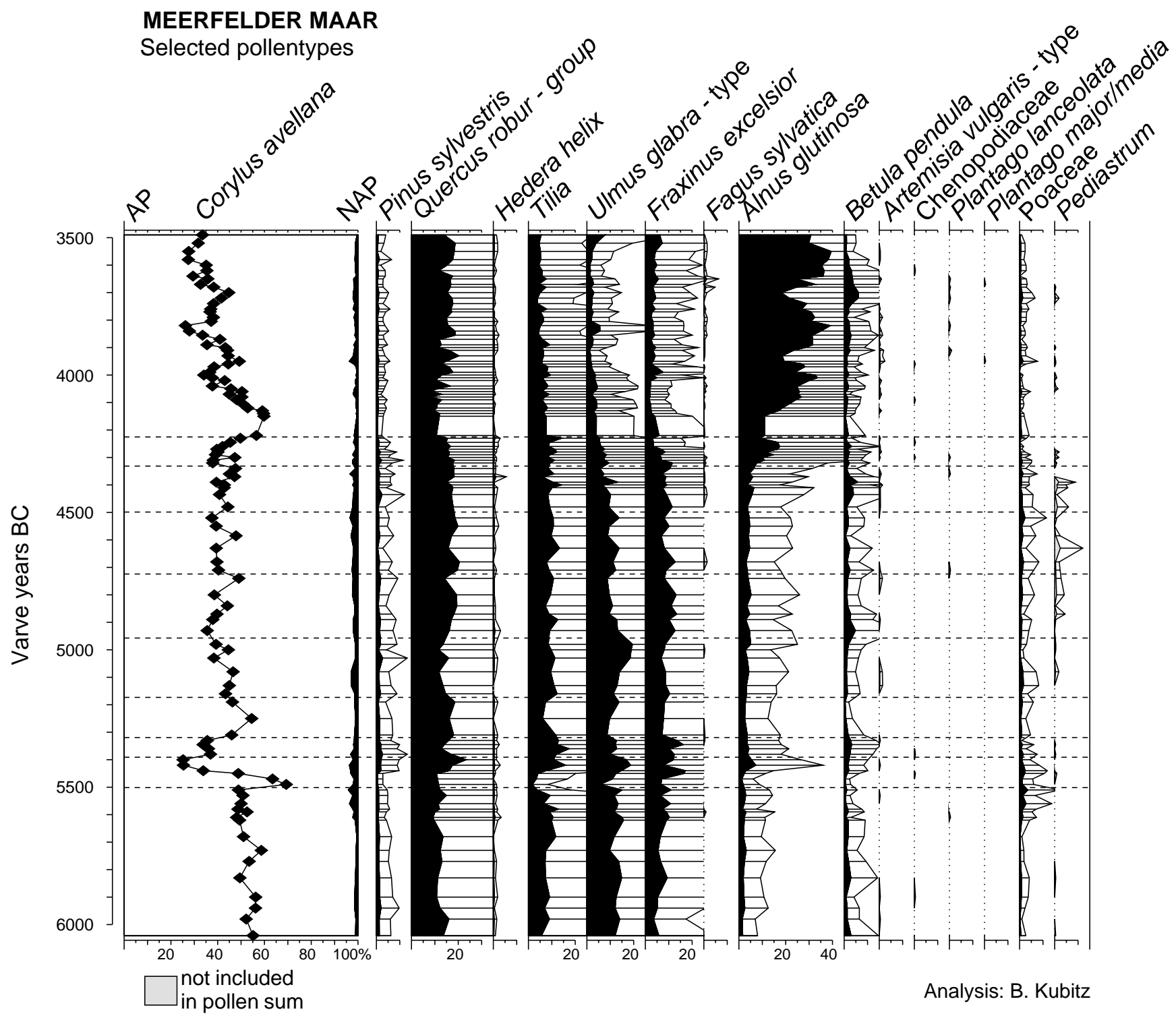

Fig. 5. Percentage pollen diagram from the Meerfelder Maar after data from B. Kubitz (rearranged and redrawn).

Corylus that lasted 100 years, Alnus representation increases. Kubitz's (2000) interpretation is that erosion, caused by woodland clearances, lead to the formation of alluvial deposits suitable for alder.

The eastern German highland zone: Thüringen: Werratal-Säulingssee (Schneider 2002) Fig. 6; Bayern: Unterfranken-Wetzhausen (Reichardt, in preparation) Fig. 7.

The Säulingssee is located at $232.5 \mathrm{~m}$ a.s.l. in a valley within the Werra-Fulda Highlands on the border between Hessen and Thüringen. This area was formerly situated between Hessen and East Germany. Prior to 1989, archaeological research was impossible in this border region. Hence, its early settlement history is practically unknown. High-resolution pollen analysis with a ${ }^{14} \mathrm{C}$-based chronology illustrates the vegetation history around the Säulingssee (Mäusbacher et al., 2001; Schneider, 2002a, b). The peat deposit of Wetzhausen lies at $295 \mathrm{~m}$ a.s.l. in a valley between the Rhön mountains and the Haßberge. Both deposits range from Lateglacial to the Middle Ages.

During the middle of the 6th millennium BC, slight changes in AP representation at Säulingssee, accompanied by the first records of Plantago lanceolata, Cerealia and Chenopodiaceae indicate Early Neolithic human impact (Fig. 6, depth $615 \mathrm{~cm}$ ). The most obvious feature is the increase in Fraxinus, which in other places in the highlands has been correlated with animal husbandry by Early Neolithic farmers (Kalis and Meurers-Balke, 1997). Stray finds of the Linear Bandkeramik culture are known from adjacent areas in Hessen and Thüringen, but modern archaeological research is 


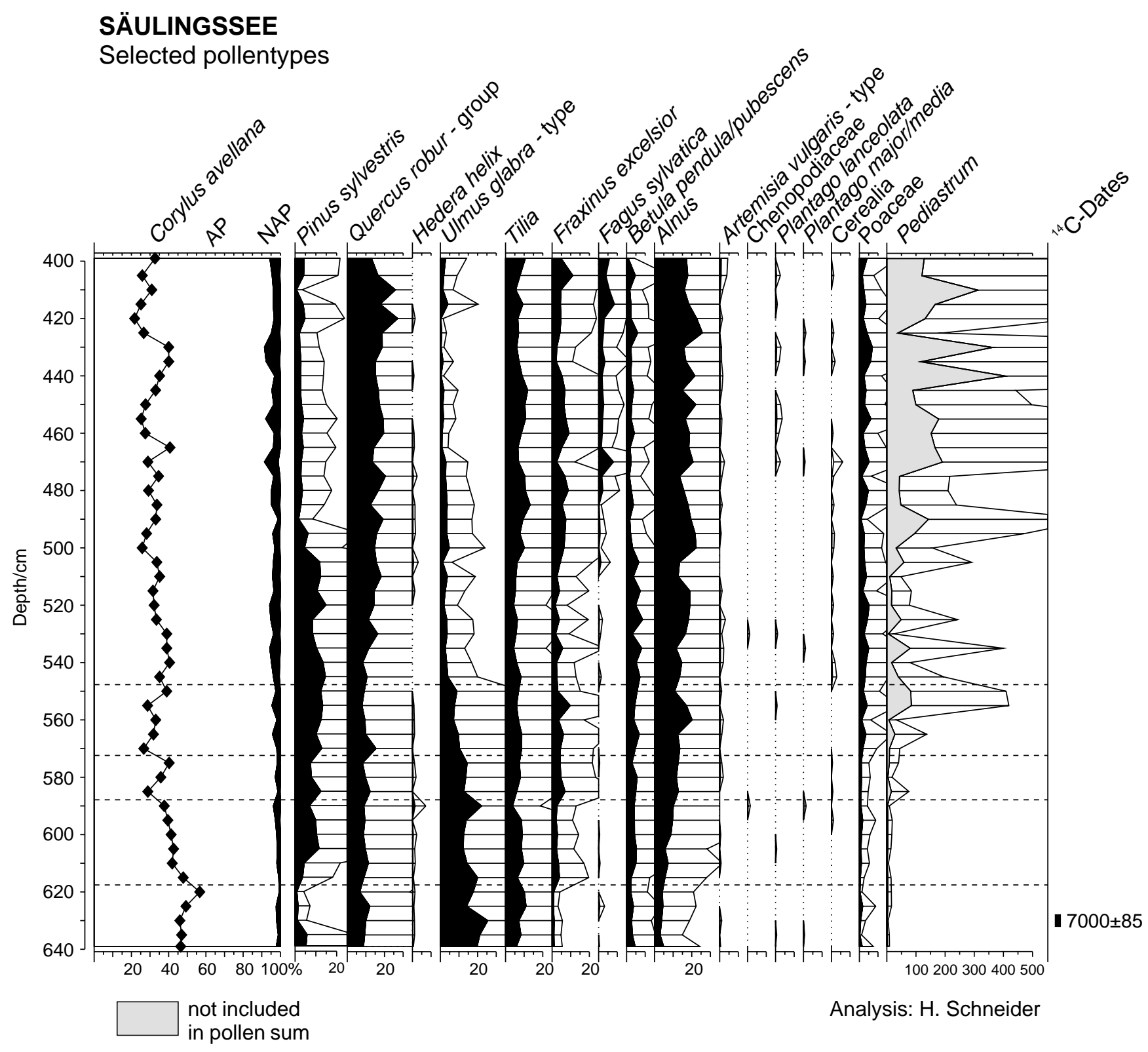

Fig. 6. Percentage pollen diagram of the Säulingssee after data from H. Schneider (rearranged and redrawn).

needed to verify a Neolithic presence near the Säulingssee. A further increase of Fraxinus, with a minimum of Tilia and an initial decrease in Ulmus are recorded shortly before $5000 \mathrm{BC}$ (Fig. $6,585 \mathrm{~cm}$ ). A similar development is shown by the Wetzhausen profile between 430 and $380 \mathrm{~cm}$ (Fig. 7). There is no doubt regarding presence of Bandkeramik farmers nearby and the pronounced peak of cultural indicators pollen, including ca 5\% Cerealia which indicates cereal production nearby.

After a forest regeneration phase in the Säulingssee profile, a further decline in Ulmus and an increase in Quercus occurs at ca 4750 BC (Fig. 6, $572 \mathrm{~cm}$ ). Simultaneously, Pediastrum increases, which indicates eutrophication of the lake water. All features point to
Middle Neolithic impact on the vegetation near the lake, although the lack of archaeological research does not allow verification. The settlement history at the Wetzhausen site is better understood, where a Rössen settlement occurs nearby. The Ulmus-decline at $366 \mathrm{~cm}$, and the increase in Betula, Corylus and Quercus may be attributed to this culture. A decline in Ulmus, similar to the classical Elm Decline, in the Säulingssee pollen diagram, with simultaneous decreases in Fraxinus and Alnus, began around 4300 BC (Fig. 6, $537 \mathrm{~cm}$ ) and was followed by a clear secondary forest cycle and pollen records for cereals, weeds and grasses. The author suggests that Younger Neolithic people were responsible for these changes, although it remains 


\section{WETZHAUSEN}

\section{Selected pollentypes}

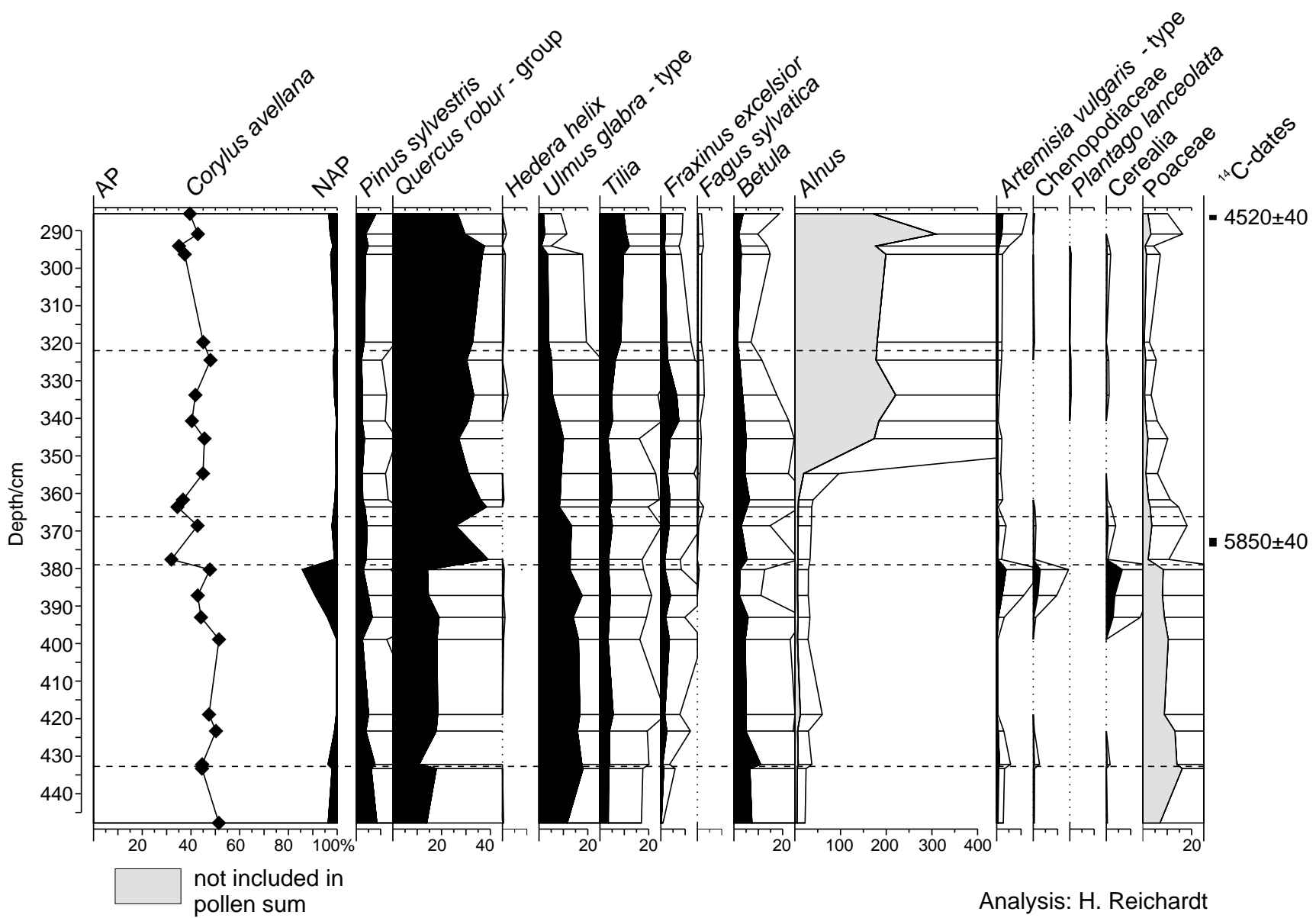

Fig. 7. Percentage pollen diagram from Wetzhausen after data from H. Reichardt (recalculated, rearranged and redrawn).

unclear whether the Michelsberg culture, known from adjacent Hessen, or the Gatersleben culture known from the neighbouring Thüringen basin, were involved. The most readily detectable human impact in the vegetation in the Werra-Fulda highlands is coupled with the least well defined archaeological period for that region.

Oceanic loess landscapes within the highland zone: Niedersachsen: Juessee in the Unteres Eichsfeld (Voigt, in preparation), Fig. 8. The Juessee is a small lake in the town of Herzberg, which is situated on the southwestern fringe of the Harz mountains. The lacustrine sediments range from Younger Dryas to the present. About $60 \%$ of the sediments are annually laminated enabling a precise local chronology. Unfortunately, the varves do not reach the present, and so a floating chronology is 'fixed' with the help of $24{ }^{14} \mathrm{C}$-dates. Ages quoted below are based on this estimate.

The Atlantic forest was dominated by lime and elm. Around $5500 \mathrm{BC}(7450$ cal $\mathrm{BP})$ there are notable changes in the pollen diagram: Ulmus and Tilia i.e. late successional trees, decrease whereas the early successional Corylus and Fraxinus increase, indicating an opening of the forest cover by human activity. This corresponds with the first settlements of Early Neolithic farmers in the Unteres Eichsfeld. The pollen signal of Bandkeramik farming differs from that at Luttersee (Beug, 1992) in that arable farming is not indicated. It is concluded that cereal production did not occur in the vicinity of the Juessee, as was the case at Luttersee. Neolithic activity in the forests nearby, however, is indicated. The expansion of Fraxinus is probably related to Early Neolithic animal husbandry, as is suggested by Kalis (1988) for comparable loess landscapes in the Rheinland. After a regeneration phase of the natural forests, a second decline in Ulmus is visible from 4950 BC (6900 cal BP) onwards. Again Quercus and Corylus increase. After ca 150 years, the pollen curves of Tilia and Quercus decline and that of Corylus reaches another maximum, pointing to even greater impact on woodland vegetation, probably by Stichbandkeramik peoples. At $4600 \mathrm{BC}$ (6550 cal BP) further changes are 


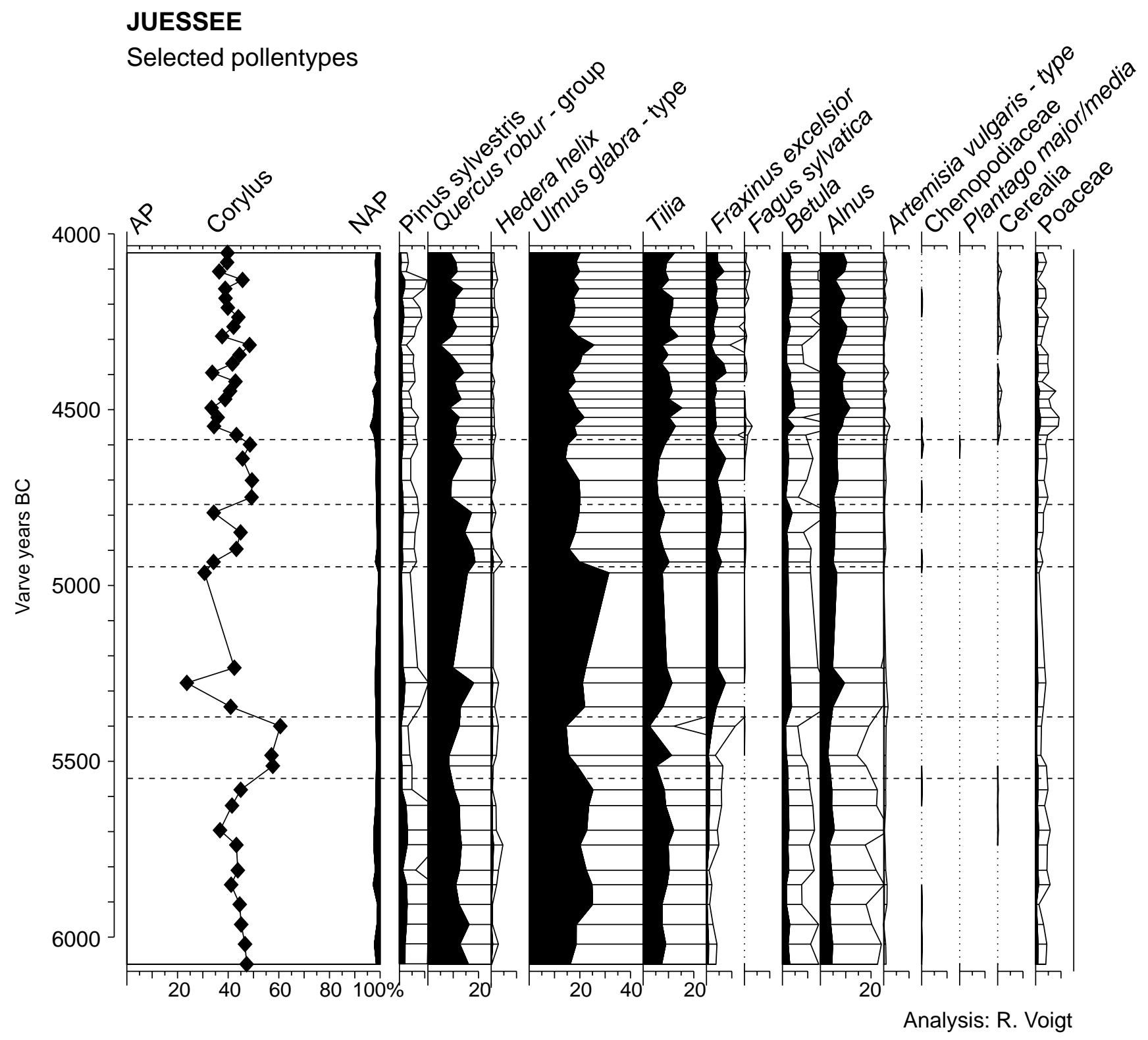

Fig. 8. Percentage pollen diagram from the Juessee after data from R. Voigt (recalculated, rearranged and redrawn).

recorded: Ulmus and Tilia increase and Corylus declines which suggests woodland regeneration. At the same time, however, Cerealia has an almost continuous curve and the increase of Poaceae and other cultural indicators show the importance of arable farming near the lake. Compared to the nearby Luttersee (Beug, 1992) the difference in the exploitation of the natural resources is remarkable. During the Early Neolithic, arable farming is well reflected in the Luttersee diagram, whereas that of the Juessee shows woodland pasture. During the Middle Neolithic Rössen culture the opposite is the case. This shows the archaeo-palynological importance of the Juessee diagram. It provides not only a detailed chronology of the vegetation history, but also a strong contrast in the vegetation and land-use record with that provided by the high-resolution Luttersee pollen diagram.

The older morainic landscape of the northern German Lowlands. Niedersachsen: Hämelsee (Müller in preparation), Fig. 9. The Hämelsee lies in the older morainic landscape of Niedersachsen at an altitude of $19.5 \mathrm{~m}$ a.s.1. in an area of sandy soils. The lacustrine sediments are laminated during greater parts of the Late- and Postglacial which have enabled the construction of a precise local chronology (Merkt and Müller, 1999). Until the expansion of the Funnel Beaker culture around $3500 \mathrm{BC}$ (5450 cal BP), no Neolithic culture is known in this area. Accordingly the changes in the pollen diagram are rather subdued. The first obvious change occurs at $4150 \mathrm{BC}(6100 \mathrm{cal} \mathrm{BP})$, when Ulmus 


\section{HÄMELSEE}

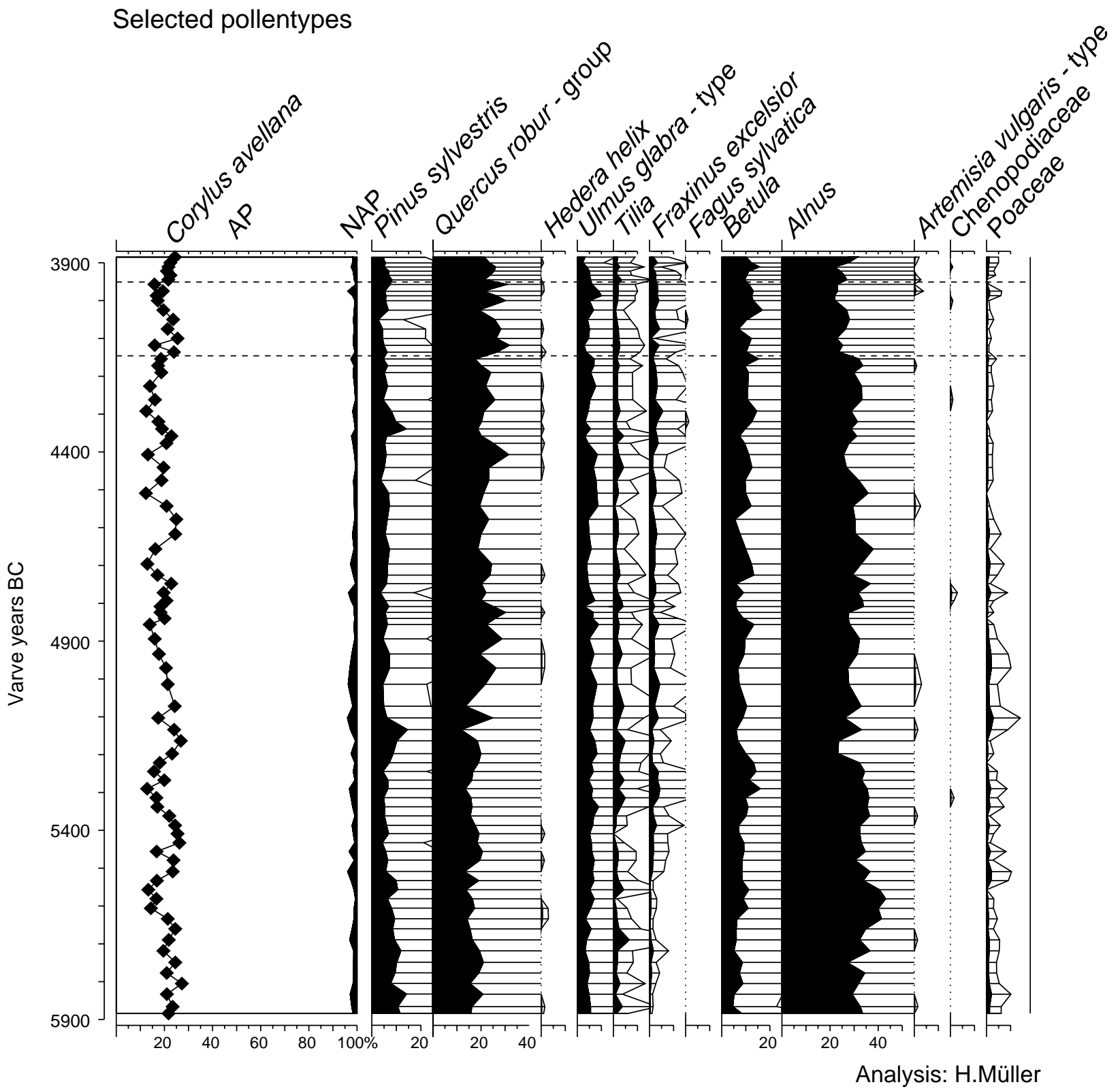

Fig. 9. Percentage pollen diagram from the Haemelsee after data from H. Müller (rearranged and redrawn).

and Alnus decrease and Quercus and Corylus increase. A comparable feature can also be seen in other pollen diagrams from the older morainic landscape of Niedersachsen or the Netherlands. Even scattered Plantago lanceolata and Cerealia pollen grains occur, which Behre and Kučan (1994) ascribe to a "pre-megalithic Funnel Beaker culture". They may also relate, however, to pastoral activities of the mid-phase of the Mesolithic Swifterband culture (sensu Lanting and Van der Plicht, 2000).

After a brief recovery of the Ulmus curve, the Elm Decline begins at 3970 BC (5920 cal BP) with an increase of Alnus, Betula and Corylus. At the same time, the
Poaceae curve increases somewhat and Plantago lanceolata is recorded, indicating human impact centuries before the arrival of the Funnel Beaker culture.

The younger morainic landscape along the Baltic Sea. Schleswig-Holstein: Flensburger Förde, Haddebyer Noor (Dörfler in preparation) Figs. 10 and 11; Rügen: Herthamoor (Endtmann in preparation), Fig. 12. The younger morainic landscape along the western coasts of the Baltic Sea had a distinctive role in neolithic settlement history. The region links the coast which has excellent fishing and hunting possibilities, with a hilly inland where there is a great variety of soil types, lakes and marshes. This area offers a high diversity of 


\section{FLENSBURGER FÖRDE}

\section{Selected pollentypes}

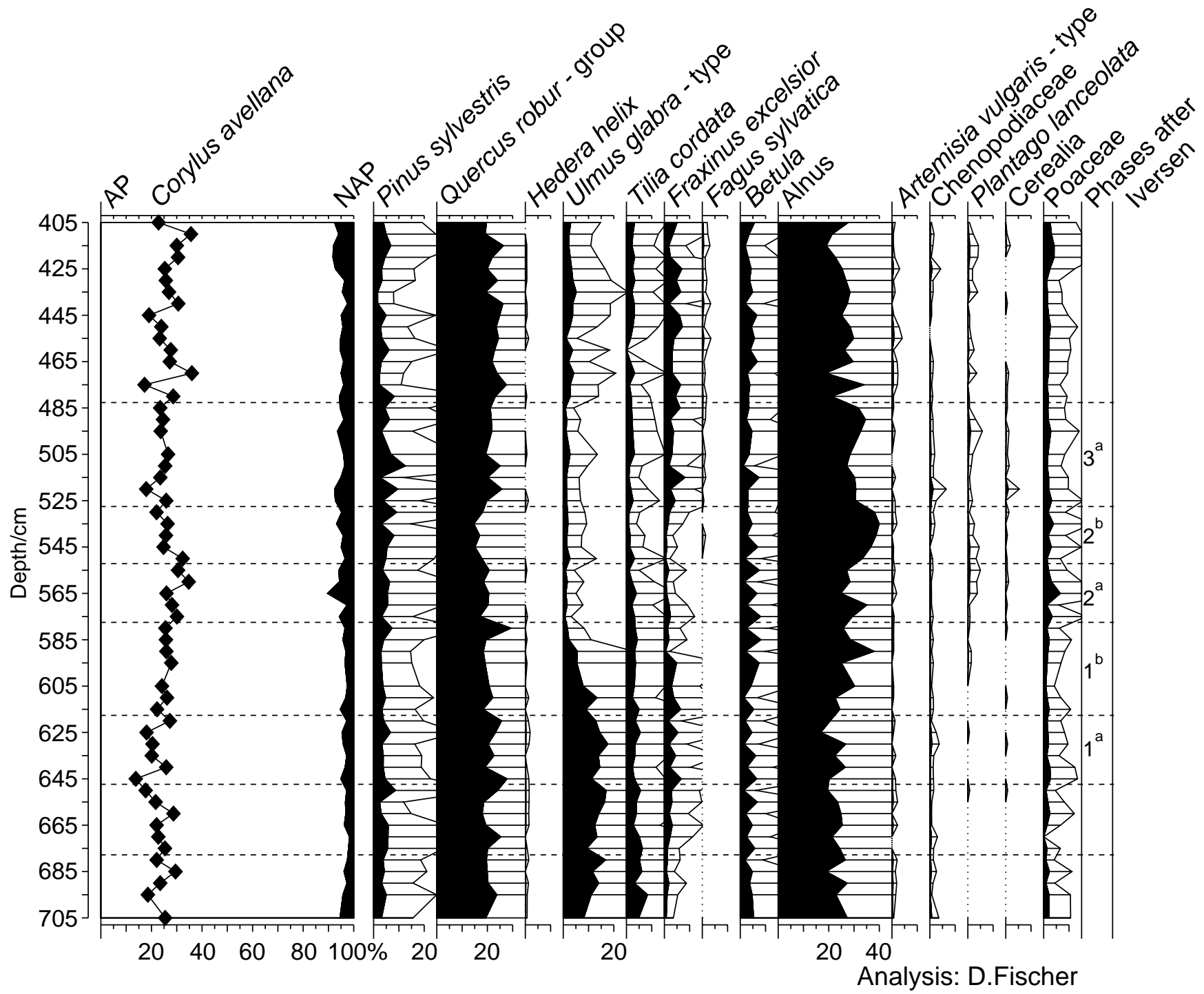

Fig. 10. Percentage pollen diagram from the Flensburger Förde after data from W. Dörfler (rearranged and redrawn).

ecotones and therefore a diverse wild life. The easy accessibility to fish, game and wild plant food provided very favourable conditions for Mesolithic life. One highly developed Mesolithic culture, the Ertebølle culture, existed there for nearly 2000 years. Although these people were acquainted with the great (Middle-) Neolithic cultures to the south and lived in an area with excellent soils for arable farming (some groups even had permanent settlements), they did not embrace arable farming but remained hunters and gatherers. Nevertheless, some Neolithic elements had already been added to Ertebølle life around $4700 \mathrm{BC}(6650 \mathrm{cal} \mathrm{BP})$ i.e. the production of pottery, the keeping of cattle (Hartz et al., 2000) and some production and consumption of cereals (Kalis and Meurers-Balke, 1998). Around 4200 BC
(6150 cal BP) more Neolithic elements were adopted by the Ertebølle people. Sheep and/or goats were introduced and a new ceramic style arose. During the Late Atlantic, however, the Litorina transgression drowned the coastal areas of the Baltic Sea. Hence, very few settlements have been excavated. The reconstruction of the former coast line of eastern Holstein (Hartz and Hoffmann-Wieck, 2000; Jakobsen et al., 2001) and the island of Rügen was therefore an objective of two working groups within the present priority programme. Pollen analysis offers a good 'off-site' view on the impact resulting from the Ertebølle culture. TroelsSmith (1954) was the first to recognise the influence of Late Mesolithic animal husbandry on the vegetation in pollen diagrams. Originally observed on the Danish 


\section{HADDEBYER NOOR}

\section{Selected pollentypes}

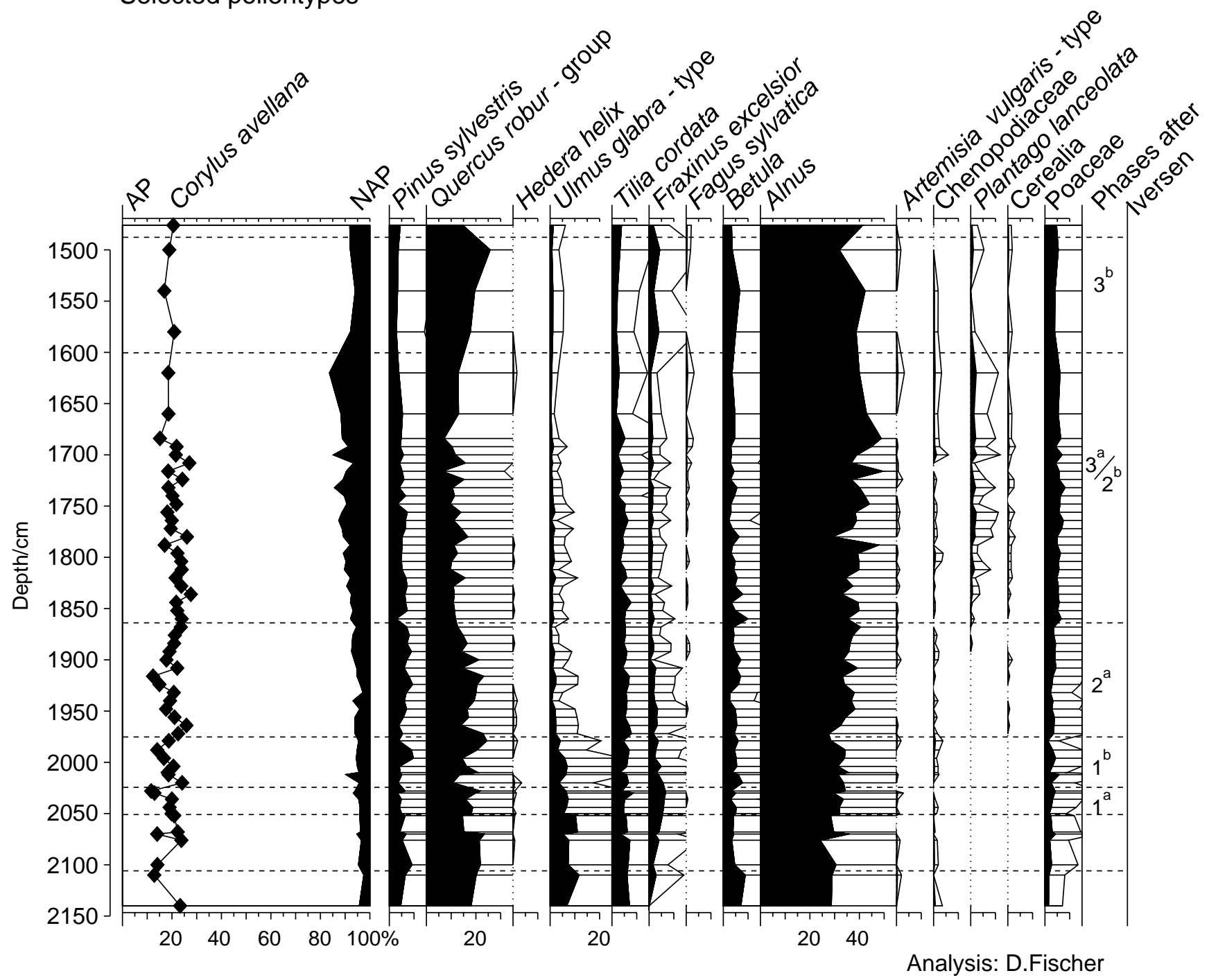

Fig. 11. Percentage pollen diagram from the Haddebyer Noor after data from W. Dörfler (rearranged and redrawn).

island of Sjælland, these phenomena can also be recognised in pollen diagrams from eastern Holstein (Kalis and Meurers-Balke, 1998). They are characterised by a substantial rise in Fraxinus, coupled with an increase of Quercus and the first decrease of Ulmus. The newly elaborated pollen diagrams from the Flensburger Förde (Fig. 10: 677-647 cm) and the Haddebyer Noor (Fig. 11: 2100-2050 cm) record such features. The Herthamoor pollen diagram from Rügen which records a decline in Ulmus and Tilia and a strong increase of Betula and Poaceae, shows a similar human impact (Fig. 12, above $677 \mathrm{~cm}$ ).

Around 3900 BC (5850 cal BP) this development turned into a real Neolithic farming economy based on arable farming and animal husbandry (Hoika, 2000), associated with the Funnel Beaker culture. Iversen's palynological characterisation of this neolithisation process in Denmark, mentioned above, also fits the situation in the younger morainic landscape of northeastern Germany (Kalis and Meurers-Balke, 1998). It can be easily recognised in the pollen diagrams from the Flensburger Förde (Fig. 10, above $647 \mathrm{~cm}$ ), Haddebyer Noor (Fig. 11, above $2050 \mathrm{~cm}$ ) and on the isle of Rügen (Fig. 12, above $660 \mathrm{~cm}$ ). The developments are, however, not quite similar. The pollen diagrams from Schleswig-Holstein begin with Iversen's (1949) phase $1 \mathrm{a}$, the Herthamoor from Rügen with phase $1 \mathrm{~b}$, which suggests a somewhat later neolithisation. The Funnel Beaker culture changed the vegetation drastically. In Iversen's phases $2 \mathrm{~b}$ and $3 \mathrm{a}$ (from approx. 3400 $\mathrm{BC}=5350$ cal BP), species like elm and ash almost disappeared and oak and lime reached a minimum, whereas early successional hazel and alder dominated the pollen spectrum. For the first time, cereal growing 


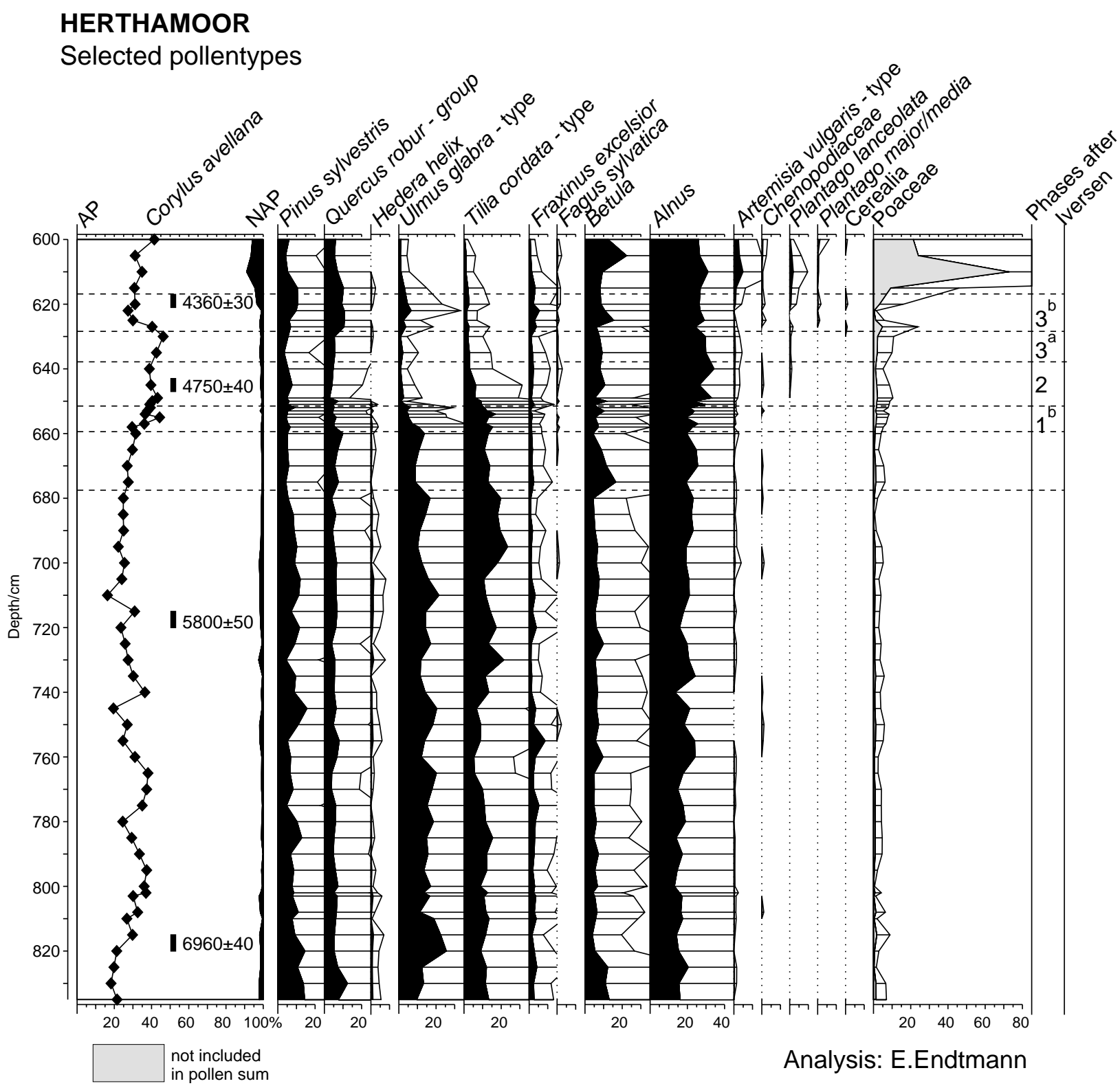

Fig. 12. Percentage pollen diagram from the Herthamoor after data from E. Endtmann (rearranged and redrawn).

was so extensive that arable activity became visible in the pollen spectrum. Elevated NAP representation includes grasses, cereals, Rumex sp. and especially Plantago lanceolata (Haddebyer Noor: 1870-1600 cm; also Dörfler, 2001).

\section{Evidence for mid-holocene changes and human impact from floodplain deposits, colluvia and soils}

\subsection{Floodplain deposits}

Fluvial systems are sensitive to environmental changes, which may result from climatic forcing but also from human impact. Both, climatic oscillations and human activity may cause changes in vegetation cover that affect river discharge, sediment load, or bank stability and hence the spatial distribution of sedimentary environments. Thus, the lateral and vertical patterns of fluvial deposits and facies units may reflect the sedimentary response of fluvial systems to allogenic controls. However, due to different sensitivities of river systems to changing environmental conditions, similar changes may cause different fluvial responses. Furthermore, the response of fluvial systems depends on the regional setting which must be taken into account when reconstructing local palaeoenvironments (Blum and Törnqvist, 2000). The interpretation of fluvial deposits in terms of detecting causes of environmental changes is therefore complex. 
For this reason, investigations of alluvial deposits should emphasise the establishment of a stratigraphic framework based on a comprehensive data set. The studies should concentrate on valleys of small to medium rivers as the fluvial deposits in these valleys closely reflect the conditions of the individual catchment areas, whereas the floodplain deposits of large rivers, with extended drainage basins, integrate the variable effects of different sub-catchments. Several study groups of the priority programme, dealing with the midHolocene period, met these conditions in their study areas (e.g. Mäckel and Friedmann 1999; Niller, 1998; Bubenzer, 2000; Schulte and Stumböck, 2000; Andres et al., 2001; Mäusbacher et al., 2001). The fluvial history of the Rhine river received special attention (Dambeck and Sabel, 2001; Dambeck and Thiemeyer 2002).

In some study areas, fluvial sediments were exposed in outcrops within gravel pits and trenches but most of the compilation of cross sections was based on corings which facilitated reconstruction of the sedimentary record. The description of cores was complemented by various analyses (e.g. grain size distribution, organic matter, calcium carbonate and heavy metals). Magnetic susceptibility and heavy mineral analyses have been applied in order to acquire information on the provenance of the deposits. Thin sections of different horizons were examined to determine the soil forming processes. Furthermore, the stable isotope data, i.e. $\delta^{13} \mathrm{C}, \quad \delta^{15} \mathrm{~N}, \quad \delta^{34} \mathrm{~S}$, yielded information on changing depositional environments. The chronological framework was based on physical dating methods, e.g. ${ }^{14} \mathrm{C}$ dating (AMS and conventional beta-counting) and optical stimulated luminescence (OSL), and relative pollen chronologies. As shown in Section 2.1, pollen records and botanical macroremains enabled reconstruction of vegetation history and climate changes, and were used to assess human impact on the environment.

Sedimentary records of most of the rivers investigated in the course of the priority programme indicate that during the Late Pleistocene and Early Holocene there were marked changes in fluvial conditions (Litt et al., 2002). For instance, at the beginning of the Younger Dryas the rejuvenation of braided river systems and reworking of older deposits took place in several drainage basins. However, during the later part of this period alluvial sediments changed from gravelly to organic-rich silt or fine sand indicating the shift to meandering systems. A further change in conditions, associated with the deposition of highly organic mud and peat in abandoned channels, occurred at the beginning of the Preboreal. This Late Pleistocene to Early Holocene succession is chronologically controlled by numerous ${ }^{14} \mathrm{C}$-data (Wunderlich, 1998; Nolte, 2000; cf. Andres et al., 2001; Mäusbacher et al., 2001; Houben et al., 2001).
At several localities, the organic deposits of Preboreal age grade into a clay-rich, mostly black sediment layer that is mostly covered by brown overbank fines. The black deposit is not restricted to abandoned channels but also extends to larger areas within the floodplain and locally encompasses the adjacent slopes. This black layer has been described by a number of researchers working on river systems of different sizes throughout central Europe (cf. reviews by Eberhardt, 1998; Wunderlich, 1998; Nolte, 2000; Rittweger, 2000). Several working groups of the priority programme also concentrated on this feature. The distinctive layer, the socalled 'Black Floodplain Soil (BFS)' according to Rittweger (2000), has been examined in small to medium drainage basins as well as in the northern Upper Rhinegraben, where Dambeck and Sabel (2001) recorded a "black clay".

Generally, the black layer is characterised by high clay content. In the Wetterau, Nolte (2000) measured average clay contents of $50.6 \%$ with maximum values of $84.6 \%$. Occasionally the silt content increases to average values of $44 \%$, especially in the lower parts of the formation. The organic content of the black material is low to moderate with an average value of ca $4 \%$ and not exceeding $12 \%$ dry weight. Calcium carbonate content is negligible. At some localities organic material from the lower part of the BFS yielded radiocarbon dates that indicate formation during the Boreal (Houben, 1997; Nolte, 2000; Andres et al., 2001; Houben et al., 2001). Urz (1995) suggested that the development of the black layer started as early as the Preboreal. Ages from the upper part of the layer are rare due to the lack of sufficient organic material allowing for reliable AMS ${ }^{14} \mathrm{C}$-dating. Thus the few dates available come from radiocarbon dating of bulk samples so that contamination cannot be excluded. In the floodplain of the Wetter river, bulk ${ }^{14} \mathrm{C}$-samples yielded ages ranging from ca 9000 to $6000 \mathrm{cal} \mathrm{BP}$ (Nolte, 2000). This fits the results from the Upper Rhinegraben, where Dambeck and Thiemeyer (in print) also suggest that the black clay was deposited in the late Atlantic period. Similar conclusions have been previously drawn by other authors mostly based on palynologic and stratigraphic evidence (e.g. Mäckel, 1969, 1970; Bork, 1983; Hiller et al., 1991).

The obvious lack of reliable ${ }^{14} \mathrm{C}$-dates from the Atlantic period is illustrated in Fig. 13 which shows the frequency of ${ }^{14} \mathrm{C}$-dates from fluvial sediments sampled in the northern Wetterau and the Amöneburg basin, both being loess covered depressions within the Hessische Senke, Germany (cf. Wunderlich, 1998; Nolte, 2000). However, this lack of data is not restricted to study areas in central Europe. Similar results were presented by Macklin and Lewin (1993) from British drainage basins. In their study areas only a negligible number of dated alluvial units fit to the period from 


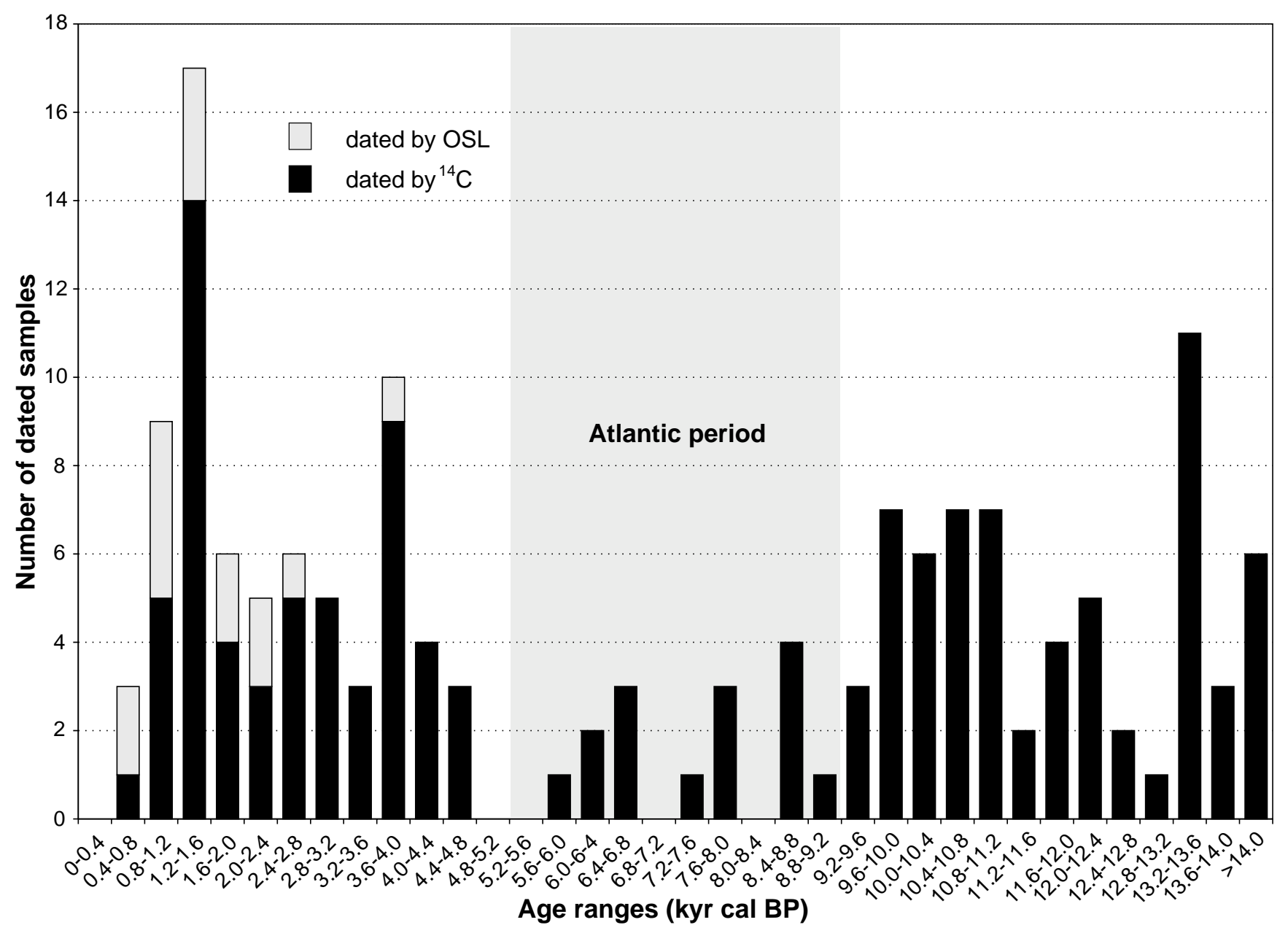

Fig. 13. Histogram showing frequency of ${ }^{14} \mathrm{C}$ and OSL dates from the study areas in the Amoeneburg basin and northern Wetterau. Note the lower frequency during the Atlantic period (after Nolte, 2000).

about 8000 to $5200{ }^{14} \mathrm{C}$ BP. The authors conclude that this phase was characterised by channel incision or stability without marked alluviation.

A stable phase during the Atlantic with net deposition tending to zero has also been suggested by Rittweger (2000) and several other authors (e.g., Schellmann, 1998). Thus, the BFS marked the land surface for a long period throughout mid-Holocene. However, it has not yet been determined, whether the black layer represents a palaeosol, e.g. a fossil Anmoor soil or a sediment layer. Although thin-sections, analysed by Eberhardt (1998), could not clearly solve this problem, Rittweger (2000) argues that both processes were involved in the development of the BFS in riverine forests (Fig. 14). On the one hand a seasonally high groundwater table in the flood plains, as is also indicated by the results of Niller (1998), may have reduced decomposition of organic material. On the other hand humic soil material from chernozems, which had developed on the adjacent slopes, may have been eroded and the finest particles slowly accumulated on the floodplain. According to Rittweger (2000), seasonal groundwater lowering during the Late Atlantic or Early Subatlantic caused the decomposition of organic material within the upper part of the layer. This desiccation process is also reflected in laminated lake sediments, which show the input of clastic material at this time (see below). It affected the sedimentary environments within the floodplain and this may be the reason for poor pollen preservation and the lack of datable material. Thus, the development of the BFS can be considered to be a multifold process that started in the early Holocene and ended in the Subboreal (Fig. 14).

Stable isotope analyses of organic carbon $\left(\delta^{13} \mathrm{C}_{\text {org }}\right)$, nitrogen $\left(\delta^{15} \mathrm{~N}\right)$, and total sulphur $\left(\delta^{34} \mathrm{~S}_{\text {tot }}\right)$ in sediment cores were made to elucidate the mid-Holocene environmental history of the alluvial plains and the formation of the BFS. Cores from the floodplains of the Ohm and Wetter rivers in the Hessische Senke (study areas Amöneburg basin and Wetterau) have been analysed (Wunderlich, 1998; Nolte, 2000). The records reveal distinctive shifts during the late Pleistocene and Holocene. However, the general trends show remarkable 

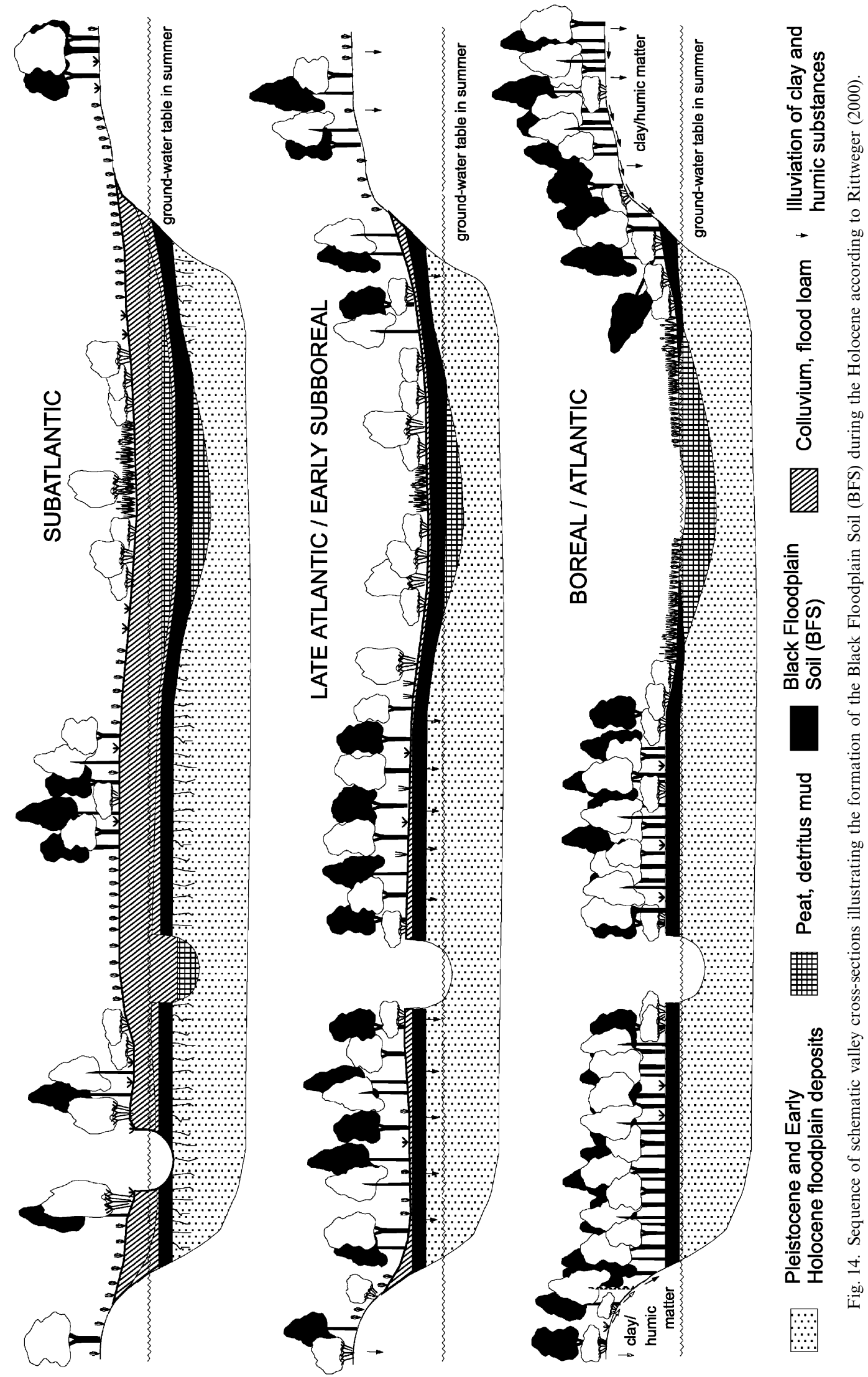

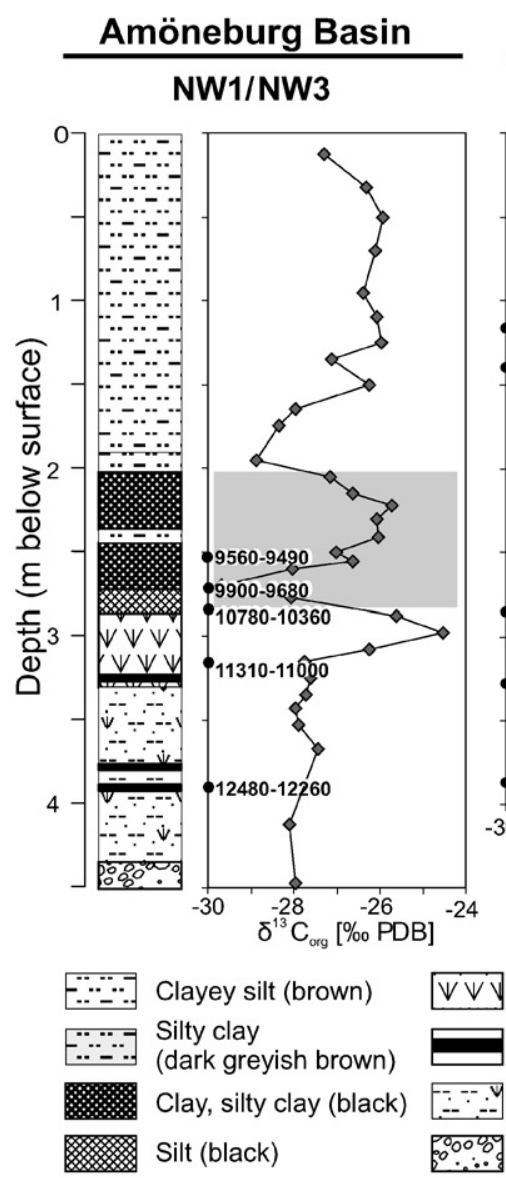

Sand, silt, organic matter (moss, twigs) Sand, gravel
Organic mud, peat, wood fragments Moss layer

northern Wetterau RKS19/20

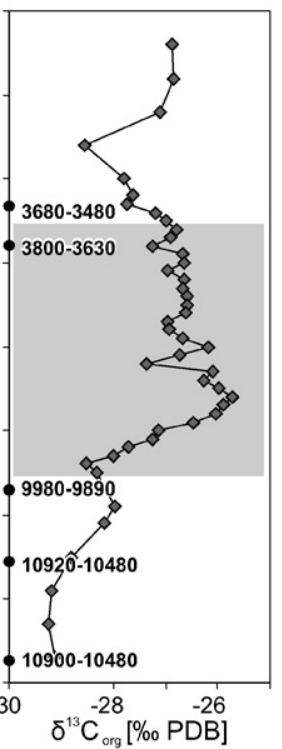

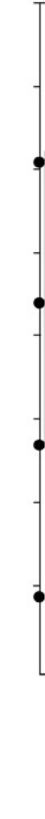
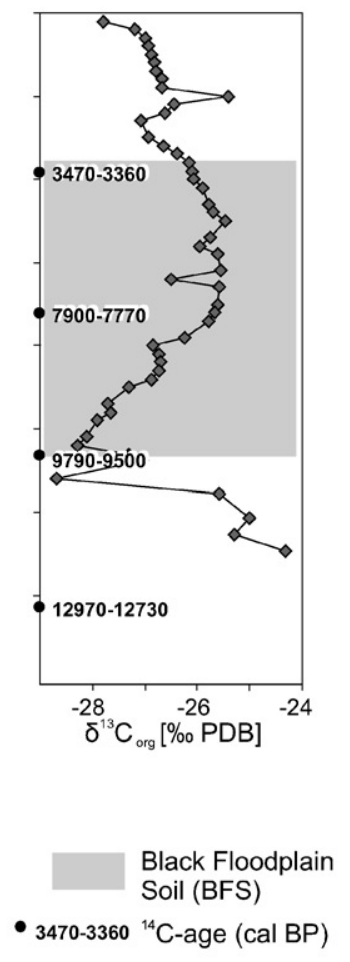

\section{Steißlinger See}

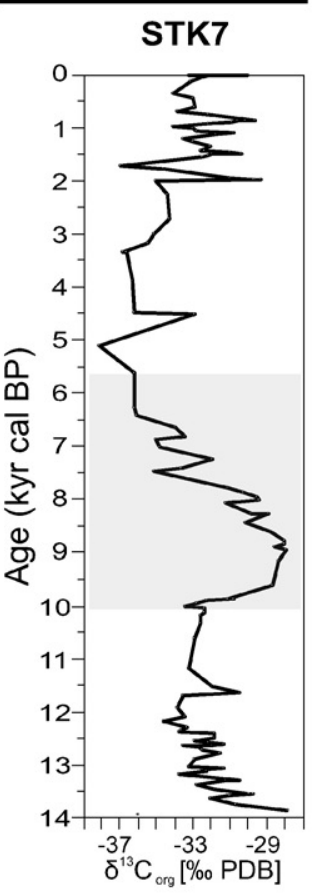

Assumed time of BFS formation

Fig. 15. Comparison of $\delta^{13} \mathrm{C}_{\text {org }}$ records from alluvial deposits in the Amoeneburg basin and the Wetterau with those from lake sediments of Steißlinger See. The isotope ratios within the reaches of the Black Floodplain Soil (BFS) show similar trends, which are comparable to those of the lake sediments that are contemporaneous with BFS-formation. Note that the records from the alluvial sediments are plotted against depth and those of the lake sediments against time (compiled from Wunderlich, 1998; Mayer and Schwark, 1999; Nolte, 2000 (data from http://www.pangaea.de)).

similarities. The illustrations in Fig. 15 indicate that the lower parts of the BFS, which were dated to the Boreal, are characterised by a substantial decrease in $\delta^{13} \mathrm{C}_{\text {org }}$ values to a minimum of about $-29 \%$ to $-30 \%$. From these minimum values at the base of the $\mathrm{BFS}, \delta^{13} \mathrm{C}_{\mathrm{org}}$ values increase to ca $-25 \%$ to $-26 \%$ and then decrease again as the top of the black layer is approached. The

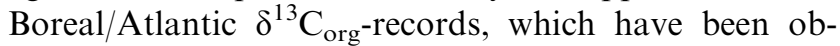
tained from the lacustrine sediment core at Steißlinger See, southwest Germany (Mayer and Schwark, 1999) show a similar shape (Fig. 15). The observed changes in $\delta^{13} \mathrm{C}_{\mathrm{org}}$ values may be caused by different processes: different sources of carbon (water, atmosphere), isotope fractionation during photosynthesis or due to decomposition as well as subsequent relocation of organic matter enriched in ${ }^{13} \mathrm{C}$. The abrupt increase of $\delta^{13} \mathrm{C}_{\text {org }}$ during the early Atlantic at Steißlinger See, which is accompanied by increasing values of $\delta^{13} \mathrm{C}_{\text {carb }}$ has been explained as signaling a negative water balance due to increased evaporation during dry climatic conditions (Mayer and Schwark, 1999). Furthermore, elevated lake productivity caused by increasing temperatures has been inferred. However, Mayer and Schwark (1999) do not exclude the possibility that the increasing input of eroded terrestrial organic matter partly caused the shift to higher $\delta^{13} \mathrm{C}_{\text {org }}$ values at the beginning of the Atlantic. According to these authors the slightly decreasing values until the Subboreal may be influenced by increasing groundwater influx due to higher annual precipitation.

The $\delta^{13} \mathrm{C}_{\mathrm{org}}$ records of the BFS show similar trends but the corresponding values are about $2 \%$ higher. In addition to the lacustrine sediments, vertical relocation of $\delta^{13} \mathrm{C}_{\text {org }}$-enriched organic matter, which developed as a result of decomposition processes in the upper part of the BFS, has to be considered. On the other hand, macroremains of aquatic plants in the lower parts of the BFS and the decrease in macroremains in the upper parts (Wunderlich, 1998) suggest that the increasing influx of terrestrial plants caused the shift to higher $\delta^{13} \mathrm{C}_{\text {org }}$ values. However, the similar $\delta^{13} \mathrm{C}_{\text {org }}$ signature in the core from Steißlinger See indicates that the $\delta^{13} C_{\text {org }}$ record, which seems to be typical for the period from the Boreal to the Subboreal, is independent from the environmental setting and probably mirrors changing 
hydrological and climatic conditions. The affect of increasing human impact can also be excluded. In the stable isotope records from Steißlinger See, the anthropogenic signal has not been observed prior to the Subatlantic (Mayer and Schwark, 1999).

The data discussed above do not clearly show that the onset of settlement and agriculture during the early Neolithic period caused severe environmental changes and alterations of the sedimentation pattern with marked aggradation of overbank fines. On the other hand, it has been reported by Litt (1988, 1992a,b) and Hiller et al. (1991) that in the drainage basin of the Weisse Elster (Eastern Germany) alluviation occurred during the early Neolithic period. In these studies a detailed stratigraphy of Holocene floodplain deposits controlled by ${ }^{14} \mathrm{C}$-data allows phases of flood loam deposition to be related to early Neolithic settlement phases. But the results also indicate that deposition of flood loam is spatially and temporally differentiated. This depends on the settlement pattern and its variation through time. Moreover, Huckriede (1972) suggests that flood loam might have been deposited in the Lahn valley during the Atlantic period due to human impact and Barsch et al. (1993) found evidence for thick accumulation of floodplain deposits induced by late Neolithic land use. However, the compilation of Niller (1998) shows that substantial accumulation of overbank fines started in the Subboreal and reached maximum levels during the Iron age.

From the investigation of fluvial deposits in small to medium but also in large drainage basins it can be concluded that the Atlantic is characterised by relatively stable conditions within the floodplains indicating that neither secondary climatic shifts nor the increase of human impact caused severe instability or widespread aggradation of flood loam. The latter may have started at the end of the Atlantic, at ca 6000 cal BP, and increased during the Subboreal.

\subsection{Colluvia and soils}

The lack of overbank fines from the early Neolithic period in most central-European valleys agrees with results extracted from other natural archives such as soils and colluvia. Truncated soil profiles give evidence that soil material was eroded, although in general the truncation cannot be related to distinctive time periods. As mentioned above eroded material partly leaves the drainage basin but some is also re-deposited in local sinks represented by the floodplains, where the eroded material accumulates as flood loam. Other sinks are located on the slopes and especially the lower slopes, where the eroded material forms colluvium. Colluvia therefore have a key role in the estimation of the amount of soil eroded. If the colluvial deposits are stratified, they even allow several phases of soil erosion to be distinguished. Furthermore, relative and physical dating methods allow the time and magnitude of soil erosion to be estimated.

Colluvial deposits, dated to the Atlantic period, have been observed in different regions and landscape units (e.g. Bork, 1983; Thiemeyer, 1989, 1991; Semmel, 1995). In general the authors concede that the thickness of the early and part of late Neolithic colluvia is less than that of deposits of the Bronze Age and Iron Age and in particular the Middle Ages. Similar conclusions have also been made by several working groups of the priority programme (Rittweger, 1997; Niller, 1998; Lang and Hönscheidt, 1999; Fischer-Zujkov, 2000; Wunderlich, 2000). In the study area of the Amöneburg basin stratified colluvium has been investigated using a multiproxy approach including the above-mentioned dating methods (Fig. 16). An extended Bandkeramik settlement was also excavated (Meyer, 2000). Palaeobotanical and mollusc records (Rittweger, 1999) revealed evidence of forest clearance during the same period. However, the evidence suggests only negligible deposition of soil material associated with these developments (Fig. 16). Thus, it appears that early Neolithic land use did not cause major soil erosion (Wunderlich, 2000).

Similar results have been observed in other regions (e.g. Niller, 1998; Lang and Hönscheidt, 1999). Niller (1998) found evidence for linear soil erosion at about 9500 cal BP. However, this single result cannot be extrapolated over a larger area nor should a period characterised by soil instability be inferred. According to the above authors the lack of noteworthy Neolithic colluvia may be explained in terms of eroded material being trapped in local sinks on the slope and redeposited at later periods as mentioned above. Lang and Hönscheidt (1999) illustrated these processes in a simple model depicted in Fig. 17. Soil erosion and re-deposition led to a pattern of colluvial deposits that was rather variable in space and that changed through time. This complicates a quantitative approach to calculating the amount of soil erosion during distinctive periods. Remnants of a trapped deposit of early Neolithic times may be the black deposit which has been identified in the Uckermark by Fischer-Zujkov (2000).

The better understanding of the soil erosion processes during the Atlantic, that resulted from the investigations within the priority programme, has benefited greatly from refined dating methods and especially OSL dating. As was elegantly illustrated by Lang and Hönscheidt (1999), ages of buried organic material as well as archaeological evidence (e.g. potsherds) only yield maximum ages for the time of deposition of colluvia. Although OSL dates have error ranges of ca $10 \%$, their combination with archaeological evidence, pollen records and ${ }^{14} \mathrm{C}$-dating, facilitates tight constraint of the chronological framework of the erosion history of a 


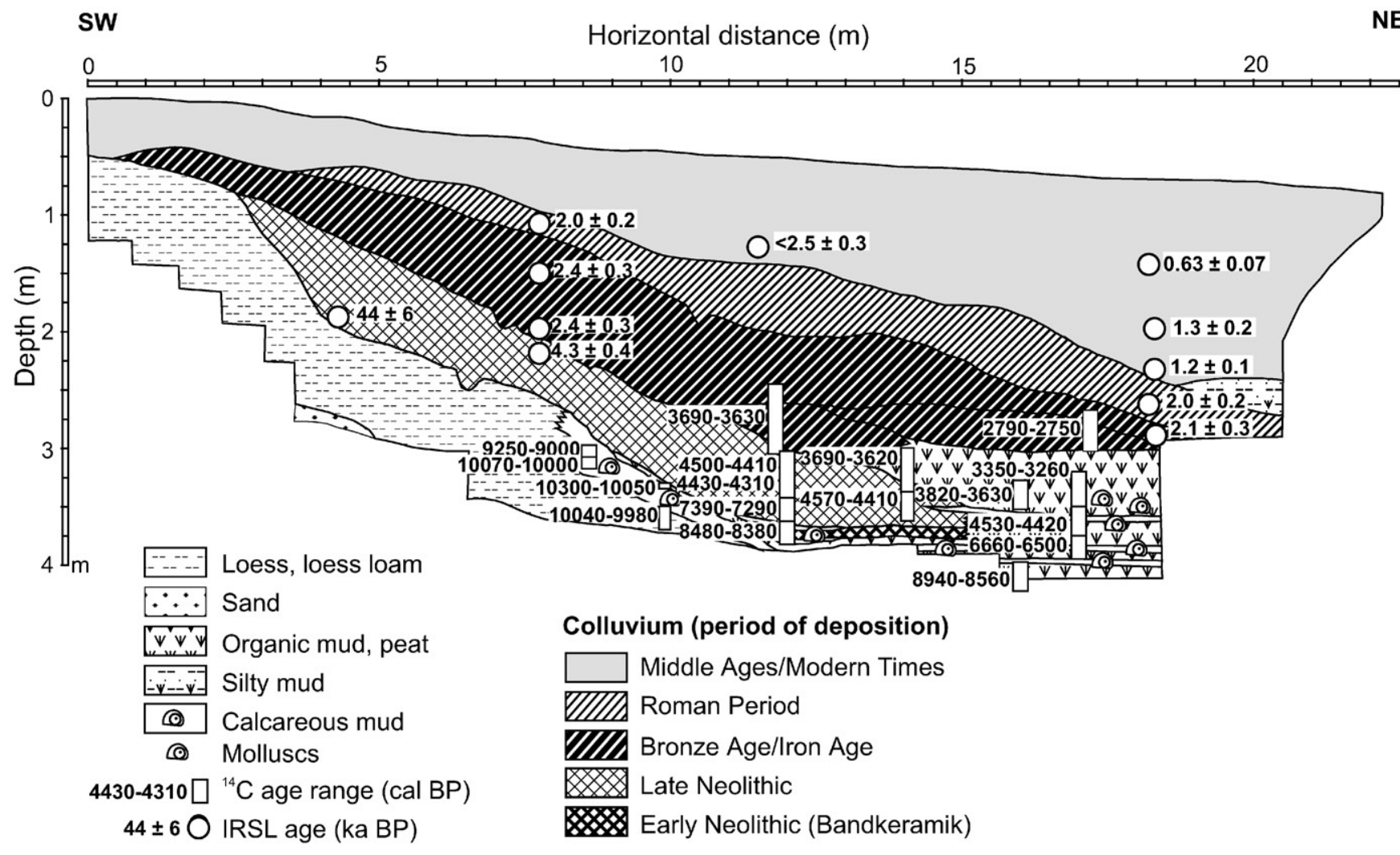

Fig. 16. Schematic cross-section at the location Mardorf-Schweinsberg (Amoeneburg basin) showing a sequence of colluvial deposits, which were dated by ${ }^{14} \mathrm{C}$ - and OSL methods. Although the site has been settled since the Bandkeramik, the colluvial deposits of this period are negligible compared to the thick colluvial layers of the following periods (based on Wunderlich, 2000).

slope and the development of a colluvium (Lang and Hönscheidt, 1999; Wunderlich, 2000).

\section{Lacustrine sediments, bogs and speleothems as archives for human and non-human induced environmental} change

\subsection{Climate}

The Atlantic is known from many earlier studies as the climatic optimum with temperatures slightly higher than during preceding and later periods, and possibly higher than at present. These earlier studies clearly show that it is difficult to find proxies sensitive enough to distinguish periods with different temperatures within the climatic optimum.

The development of forest in lowland areas did not show any indication of fluctuating palaeotemperatures during the climatic optimum. However, a thinning out of the forest was observed on the Brocken, Harz Mountains at $1450 \mathrm{~m}$ asl, at the end of the Atlantic and during the early Subboreal which Beug et al. (1999) ascribed to a cooler climate.

Schönfelder and Steinberg (1998), using information derived from transfer functions for the relation diatom-
TP and diatom-TN (Fig. 18), suggest a rapid warming during the Atlantic. Otherwise, the consistent and step wise eutrophication of the aquatic environment at Müggelsee (Brandenburg) after 9000 cal BP cannot be explained by an increased supply of nutrients from the river Spree alone. Schönfelder and Steinberg (2000) have also attempted to reconstruct palaeotemperature using sediments from Großer Treppelsee (Brandenburg) and including a larger dataset from 84 sites. A temperature-diatom relationship indicated by inferred dissolved organic carbon (DOC), as used in lakes in Canada, was shown to be not valid in Brandenburg. However, the ratio DOC/TP reflects the degree of dystrophy and can be used to evaluate relative temperature in lakes at higher latitudes where DOC is relatively high at lower temperatures, where mineralisation is reduced. Diatoms are bio-indicators for DOC/TP (Schönfelder and Steinberg, 2000). Moderate warming during the Preboreal and Boreal (terrestrial vegetation indicates warming after $9600 \mathrm{cal} \mathrm{BP}$ ) is interrupted by a short dry warm period $8500-9500$ cal BP, peaking at 9200 cal BP (Fig. 19). A steady decrease of the DOC/ TP-ratio after $8600 \mathrm{cal} \mathrm{BP}$ with interruptions during the Subboreal is interpreted as the result of rising temperatures in combination with increased groundwater supply. 

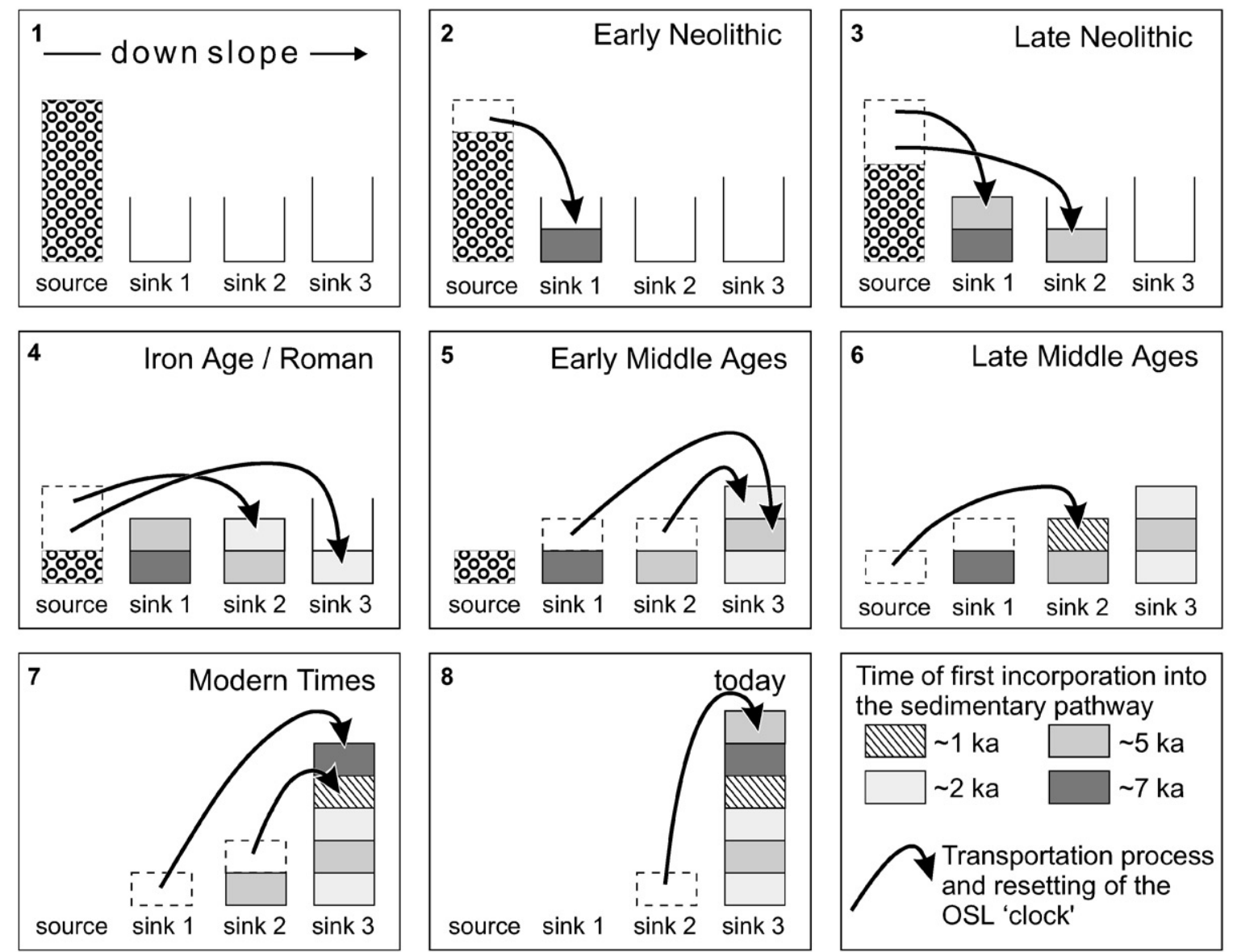

Fig. 17. Cascade model illustrating soil erosion and re-deposition processes on slopes explaining the lack of Early Neolithic colluvia at the lower slopes, which has been reported from many study areas (from Lang and Hönscheidt, 1999, rearranged).

Voigt et al. (2000) observed a gradual and consistent warming from the end of the Boreal $(9700 \mathrm{cal} \mathrm{BP})$ in the Juessee (Fig. 20). This was determined from marked changes of the terrestrial plants and macrophytes and the composition of diatom communities: species usually associated with boreal-arctic-alpine environments disappeared, whereas macrophytes spread, which require warmer temperatures. The warmer climate, lasting during the entire Atlantic, was interrupted by a cooler spell between 8000 and 7500 cal BP.

Stalagmites (speleothems) in karstic caves have a high potential for palaeoclimatic research due to their gradual growth over thousands of years, their laminated structure and new techniques requiring minimal amounts of sample material such as $\mathrm{Th} / \mathrm{U}$ (TIMS) dating and mass spectrometry to measure $\mathrm{O}$ and $\mathrm{C}$ isotopes .

Several stalagmites from caves in the Sauerland (B7) and at the northern fringe of the Bavarian Alps (Hölloch, see map, Fig. 1) have been investigated (Niggemann et al., 2000, Wurth et al., 2000). Changing $\delta^{13} \mathrm{C}$ and $\delta^{18} \mathrm{O}$ values are the result of fractionation processes $\left(\mathrm{CO}_{2}\right.$ degassing, evaporation and Rayleighfractionation of precipitation) which are related to temperature and precipitation changes. The $\delta^{13} \mathrm{C}$ and $\delta^{18} \mathrm{O}$ curves co-vary during the time slice considered here (Fig. 21). Heavier isotopic values together with an abruptly increasing extension rate (increase in length of stalagmites) and changes of the microfabric, point to a warmer and drier climate from 9800 to 9600 cal BP (late Boreal) onwards and lasting throughout the entire Atlantic. Both isotope curves and the extension rate drop to a somewhat lower level during the Late Atlantic and rise only for a short period at the transition Atlantic/Subboreal, which may indicate a more humid and slightly cooler period. The warmer climate ends at the beginning of the Subboreal (ca 6000 cal BP).

The biological methods applied in the studies of the Priority Programme and used to assess changes of palaeotemperature confirmed a substantial rise around the beginning of the Atlantic with a possible minor setback near the transition to the Late Atlantic which was probably cooler than the Early Atlantic. Studies of stable isotopes corroborated these qualitative results, but did not produce quantitative temperatures.

Temperature is accepted as the dominant climatic factor in the modern discussion on climate. The climatic 


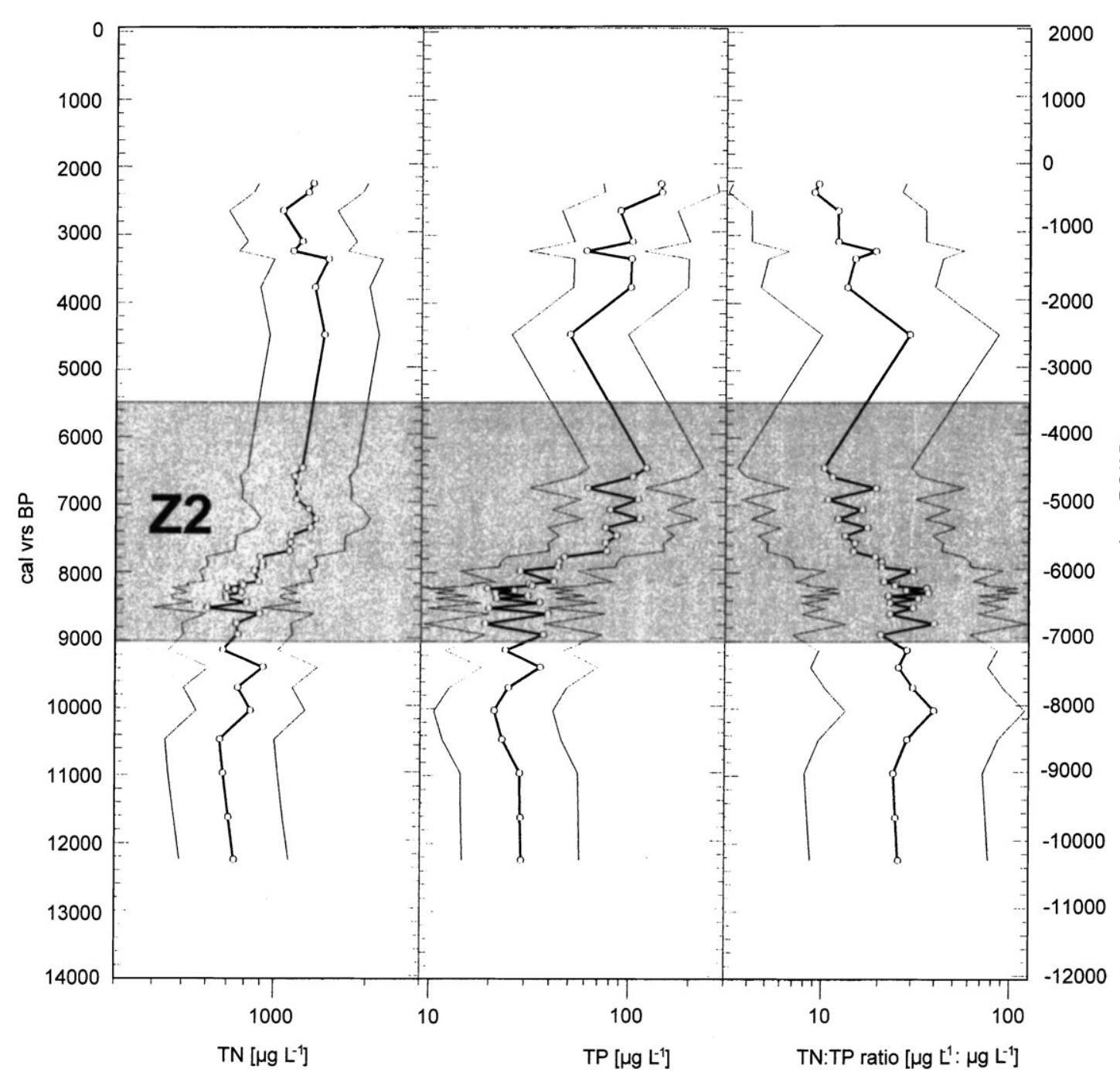

Fig. 18. Changes in the concentration of total phosphorus (TP) and total nitrogen (TN) based on fossil littoral diatoms and the ratio between these elements in the Müggelsee (Schönfelder and Steinberg, 1998).

role of precipitation and humidity is less recognised in the public mind and relatively neglected as a field of research in Germany. There are, however, some proxies, admittedly of varying quality, in several types of archive which clearly point to palaeohydrological changes during the Holocene.

The growth of mires began in the Harz mountains at the end of the Younger Dryas and continued during the entire Holocene. According to Beug et al. (1999) it was never dry enough on the Harz mountains to substantially reduce growth of mires. The elevated pluviosity of this relatively elevated area, which is influenced by Atlantic weather systems, and geological and geomorphological features are undoubtedly important factors. Increased vertical and horizontal growth of peat occurred during the Late Atlantic and Late Subboreal, indicating a more humid and cooler climate. This is corroborated by indications of an episodical opening of the forest on the hilltop of the Brocken, the highest peak in the Harz, during the Late Atlantic and Early Subboreal, which points to a cooler phase.

Increased growth of mires is usually assumed to indicate wetter bog surfaces and consequently point to a more humid climate. However, Jerz et al. (2000) and Schneider $(2002 a, b)$ have found that peat layers intercalated in gravel cones and gravelly sands in valleys and basins along the margin of the Bavarian Alps (M1-M3 in Fig. 1) were formed during drier periods of the Lateglacial and Holocene. Gravel, sand and silt were usually deposited at these sites and erosion took place during periods of increased precipitation and/or snow melt. Growth and preservation of peat could only take place when movement of clastic material ceased. This occurred with decreased water supply to rivers and streams. These findings are paralleled in a few cases with lower water levels in pre-Alpine lakes 


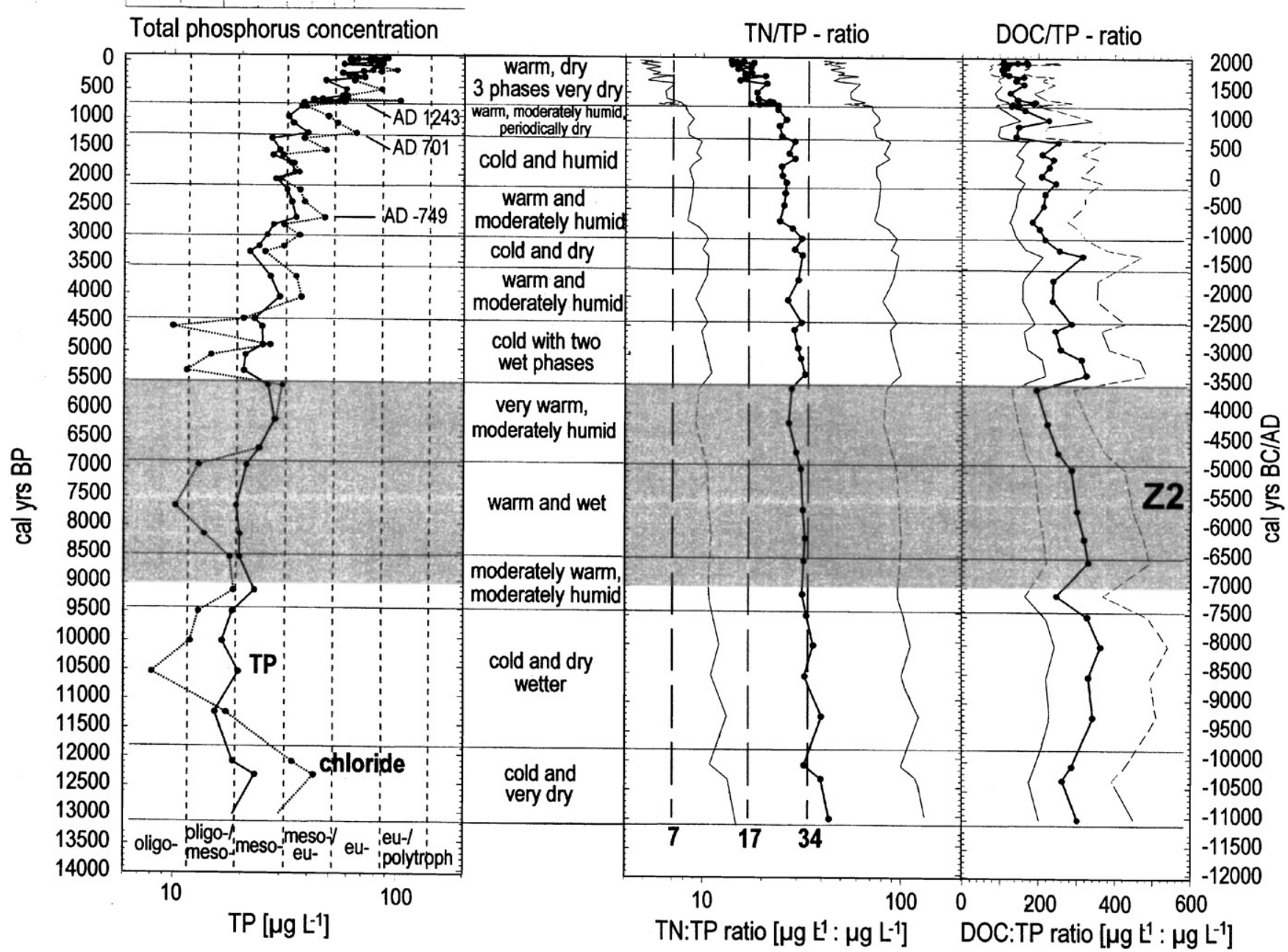

Fig. 19. Changes of climate and water quality of the Großer Treppelsee (Brandenburg, Germany) derived from diatom-indicated concentrations of phosphorus, chloride, DOC and the sedimentation rate. (Schönfelder and Steinberg, 2000).

and with soil formation. Jerz et al. (2000) found four peat horizons which were synchronous in three basins, i.e. at Agathazell (M1) some $160 \mathrm{~km}$ west of Chiemsee (M3) and Murnau (M2) which lies in between.

A relatively thin peat ( $\mathrm{H} 2 \mathrm{a}$ in Fig. 22) was formed during the Preboreal (11700-10500 cal BP). The next peat layer $(\mathrm{H} 2 \mathrm{~b})$ follows after a short interruption by coarse gravels at ca 10000 cal BP. Peat H2b is frequently interrupted by seams of coarse clastics. Accumulation and erosion with consistent hiatuses at many sites take place during the Late Atlantic again pointing to higher transport energy resulting from increased precipitation. The last peat layer (H3 in Fig. 22) from the climatic optimum occurring at the transition from the Late Atlantic to the Subboreal is slightly older in the Chiemsee basin (7000-6000 cal BP, M3 in Fig. 1) than at Agathazell (7000-5000 cal BP, M1) to the west. The results from 203 Radiocarbon dates and 342 palynological dates applied to some $2300 \mathrm{~m}$ of cores and samples from more than 1000 handdrillings could only provide a rough and imprecise chronology. However, the overall palaeohydrological picture agrees with that derived from the highly resolved data from lacustrine sediments.

Hiatuses combined with steeply inclined layers of sand and coarse organic detritus and thinning out of sediment strata on the margins of the Hämelsee (Kleinmann et al., 1997, 2000), were traced by pollen analysis of core sequences from the margins to the profundal zone where detailed analyses were carried out. Pronounced changes in sedimentology, geochemistry and the fossil records corresponded with the hiatuses and the sand layers. Decreased quality of lamination and values for redox elements such as $\mathrm{Fe}$ and $\mathrm{Mn}$ indicated reduced anoxia in the profundal zone, while the micro-fauna and flora pointed to oscillating trophic conditions. 


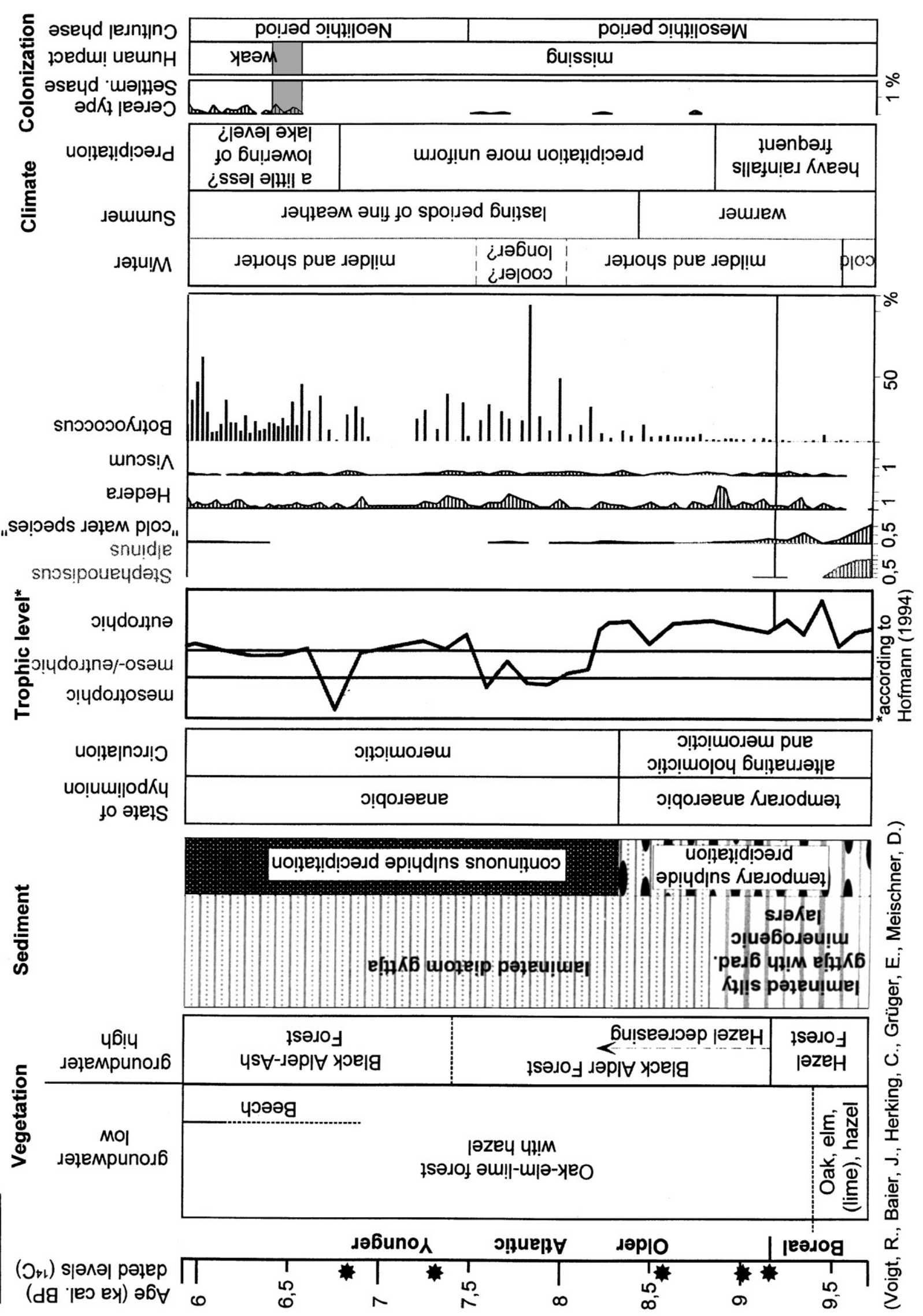




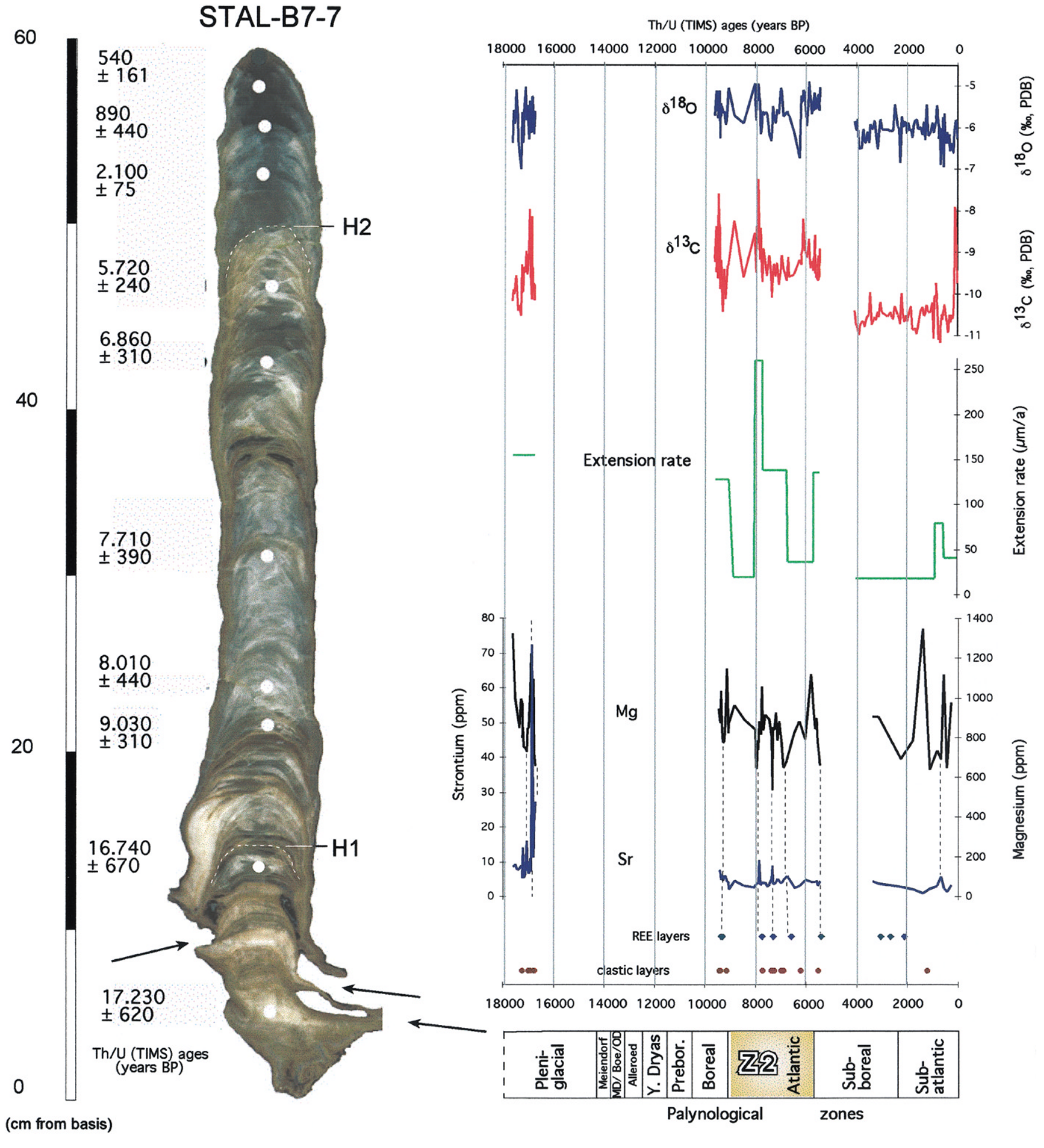

Fig. 21. Stable isotopes, extension rate and selected chemical elements of stalagmite \#7 dated by U/Th (TIMS) from B7 cave (Sauerland) (Niggemann et al., 2003).

These observations are best explained in terms of climatically induced lake-level changes as the lake is only fed by groundwater and precipitation. Barium concentrations are controlled by evaporation and have been used as a reliable tracer where other proxies are less informative.
The greatest lowering of lake-levels occurred during the upper Preboreal (11 160-10800 cal BP: time control is based on varve counts). According to geochemical and sedimentological evidence the level was repeatedly lowered to about $5-7 \mathrm{~m}$ below the modern level over a period of 360 years (Fig. 23). The next pronounced 


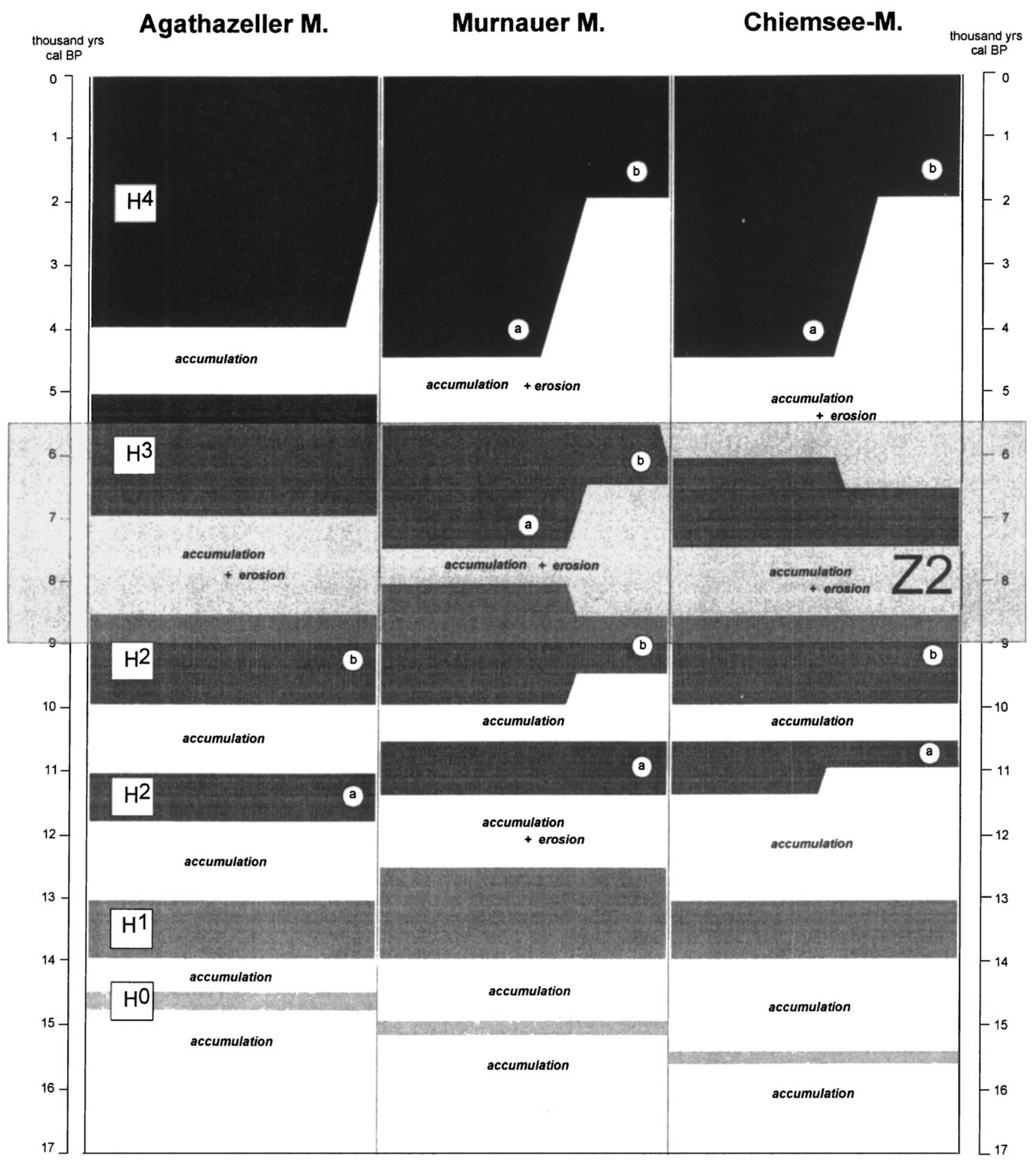

Fig. 22. Peat-building phases between accumulation/erosion phases with clastic sedimentation in three mires along the northern border of the Alps, in Bavaria. Peat-building suggests reduced river activity (Jerz et al., 2000).

lowering of lake-level at the end of the Boreal (92509340 cal BP) was not so great and lasted only 90 years. During the Early Atlantic a series of minor depressions of lake-level occurred (8800-7850 cal BP) with a climax at ca 8120 cal BP. They were somewhat more than 100 years apart and each was of some decades duration.
Another lowering occurred during the Upper Atlantic (7000-6750 cal BP). And a dry period close to the onset of the Subboreal (6200-5950 cal BP) concludes the series. The Boreal and Upper Atlantic had high water levels, probably highest during the lower half of the Holocene and somewhat higher than today. The limnic 


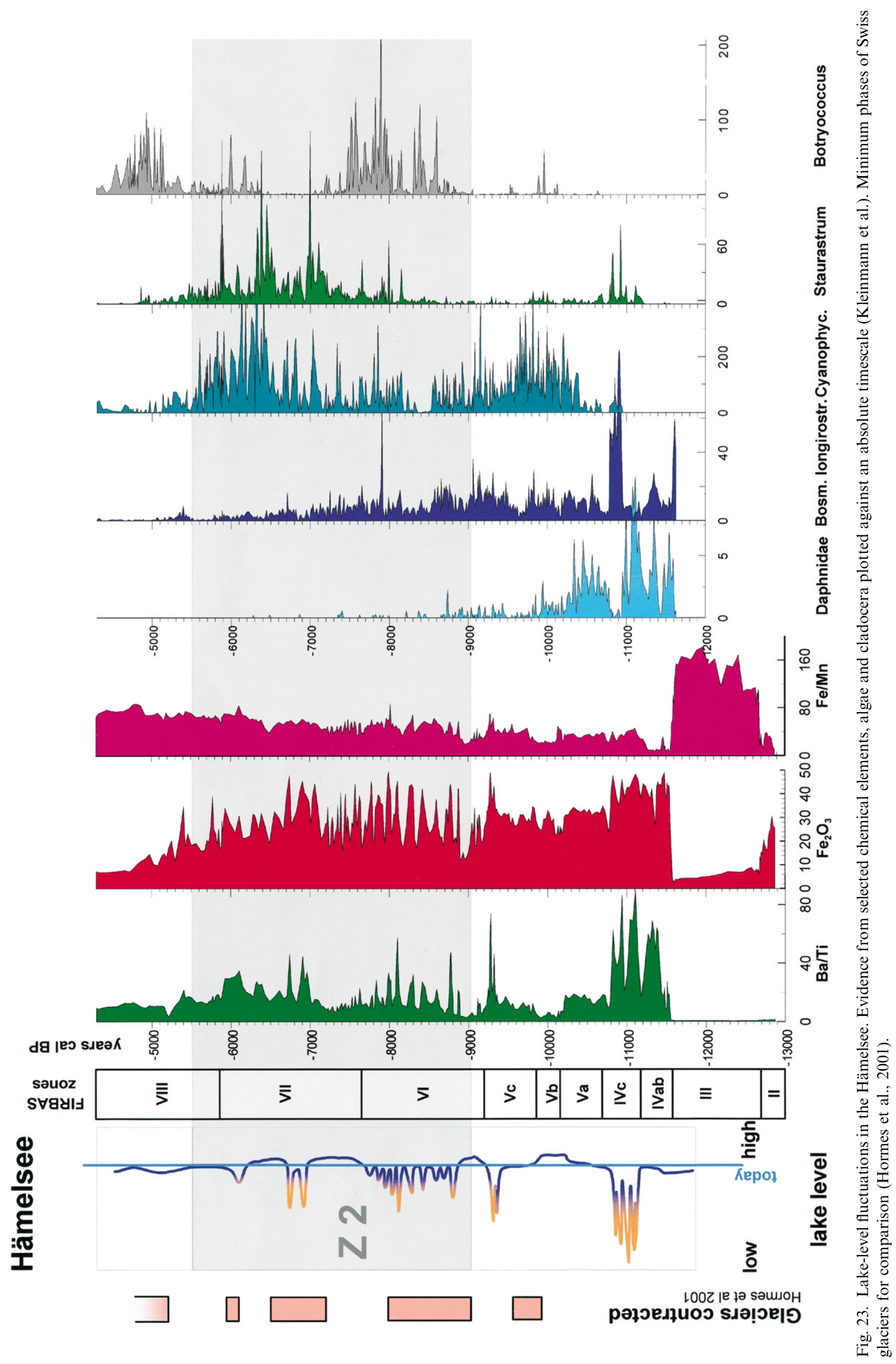


regime was later changed by human activity which prevents the detection of later water level fluctuations. With one exception, the periods with low lake levels in the Hämelsee match the phases of glacier retreat in the Swiss Alps which implies a high variability of precipitation with large amplitudes (Hormes et al., 2001) (Fig. 23). It should be borne in mind that the age determinations of the phases of ice retreat are, for systematical reasons, 100-200 years too young (Hormes et al., 2001), so that it may be too early to seriously compare the phases of glacier retreats with low lake-levels in Germany. However, the age ranges of glacier retreat of 9910-9550, 9010-7980, 7250-6500 and 6150-5950 cal BP are promising. Until now, only advances of the glaciers were considered in palaeohydrology and parallelled with high lake-levels (Haas et al., 1998; Magny, 1998).

Low values of total phosphorus (TP) inferred from transfer functions applied to diatom assemblages in the Müggelsee, east of Berlin, indicate low precipitation in the catchment area of the tributary, the Spree, during the Preboreal (Schönfelder and Steinberg, 1998). A new transfer function (now based on 84 sites and 304 bioindicative taxa) applied to the sediments of the Großer Treppelsee uses the diatom-chloride relationship (Schönfelder and Steinberg, 2000). Higher concentrations of chloride in the lake result from increasing groundwater recharge rich in chloride. Elevated surficial runoff is poor in chloride and indicates increased precipitation, possibly during spring when the soil is still frozen and sealed. These indications in conjunction with other parameters, such as inferred temperature (see above), inferred nutrients and bio-indications from diatom analysis, provided information on relative humidity. The Preboreal and the early part of Boreal are characterised by moderately increasing humidity after a cold and very dry Younger Dryas (Fig. 19). The transition, Boreal/Atlantic (9200 cal BP) is not only warm but also very dry. Strongly decreasing concentrations of chloride, TP, and TN during the Late Atlantic are interpreted as resulting from flushing of the lake due to a corresponding increase of the annual precipitation. Some data from Großer Treppelsee agree with lake status data found elsewhere, others are somewhat out of phase or have not been detected. This applies even more so to the Juessee from where no lake-level changes are reported except a possible drop from 6750 to $4780 \mathrm{cal}$ $\mathrm{BP}$ as interpreted from finds of littoral diatoms and submersed macrophytes which do not point to more available nutrients but to the decreasing distance between the drill site and the littoral (Voigt et al., 2000). A tentative interpretation for a period of two millennia is only partly in agreement with results from other sites.

The Degersee, south western Germany, is exclusively fed by precipitation and groundwater. The sedimenta- tion line in the lake was about $2-2.5 \mathrm{~m}$ below the modern lake-level during most of the Holocene, as was shown by cores along transects from two sides of the lake with the sediments of all periods deposited up to that level. However, sediments of Preboreal age are not preserved in cores shallower than $9 \mathrm{~m}$ below the modern lake level. Kleinmann et al. (in preparation) deduced from this hiatus a lake level that was about $7 \mathrm{~m}$ lower than today. Sediments of Preboreal age containing reworked pollen and microfauna and layers rich in sand, from deeper parts of the lake corroborate this interpretation. Similar features, but without apparent hiatuses at shallower sites, occur repeatedly until the upper part of the Boreal, which point to more frequent but less pronounced fluctuations. Detailed studies are hampered as the sediments are not laminated.

Similar observations were made in the sediments of the Steißlinger See. Erosion of littoral sediments during the Preboreal as a result of low lake-level ceased after $10450 \mathrm{cal}$ BP indicating a lake-level rise during the Boreal (Eusterhues et al., in press). Increased detrital input around $8200 \mathrm{cal} \mathrm{BP}$ is again attributed to a low lake-level. However, the $8.2 \mathrm{k}$ event could also account for the clastic input (Eusterhues, 2000), which in turn agrees with the isotopic record (see below). A combined malacological and sedimentological study of a core from the littoral revealed repeated fluctuations from the Younger Dryas to the beginning of the Atlantic (Schmidt, in preparation), a higher lake level during the Atlantic and lower levels during the early Subboreal.

Critical evaluation of the isotope records for carbon, nitrogen, oxygen and sulphfur from Steißlinger See by Mayer and Schwark (1999) provided good insights into palaeoclimatic conditions at this lake site (Fig. 24). Relatively warm and dry conditions prevailed during the Preboreal, with a cooler and/or wetter climate returning in the Boreal. The climate changed again at the beginning of the Atlantic (approx. $9000 \mathrm{cal} \mathrm{BP}$ ) when most isotopic ratios rapidly increased in a compelling covariance suggesting warmer temperatures along with rising productivity and evaporation. This period ended near the Early/Late Atlantic transition (8000 cal BP) when increased precipitation caused the groundwater influx to increase steadily and remain high until today.

Organic geochemistry adds an interesting insight to the study of stable isotopes. The short-chain fatty acids from algae are ubiquitous in the sediments since the beginning of the lake (Fig. 25). The long-chain fatty acids of terrigenous plants occur only in pulses that are contemporary with higher lake-levels in the earlier Holocene. Each pulse appears to begin suddenly (10000, 8000 and $6000 \mathrm{cal} \mathrm{BP})$ and then fades out (Schwark et al., submitted).

Clastic layers intercalated in the calcite matrix of speleothems of the B7 cave (Fig. 1) in Sauerland (Niggemann et al., 2000, Fig. 21 with stalagmite \#7), 


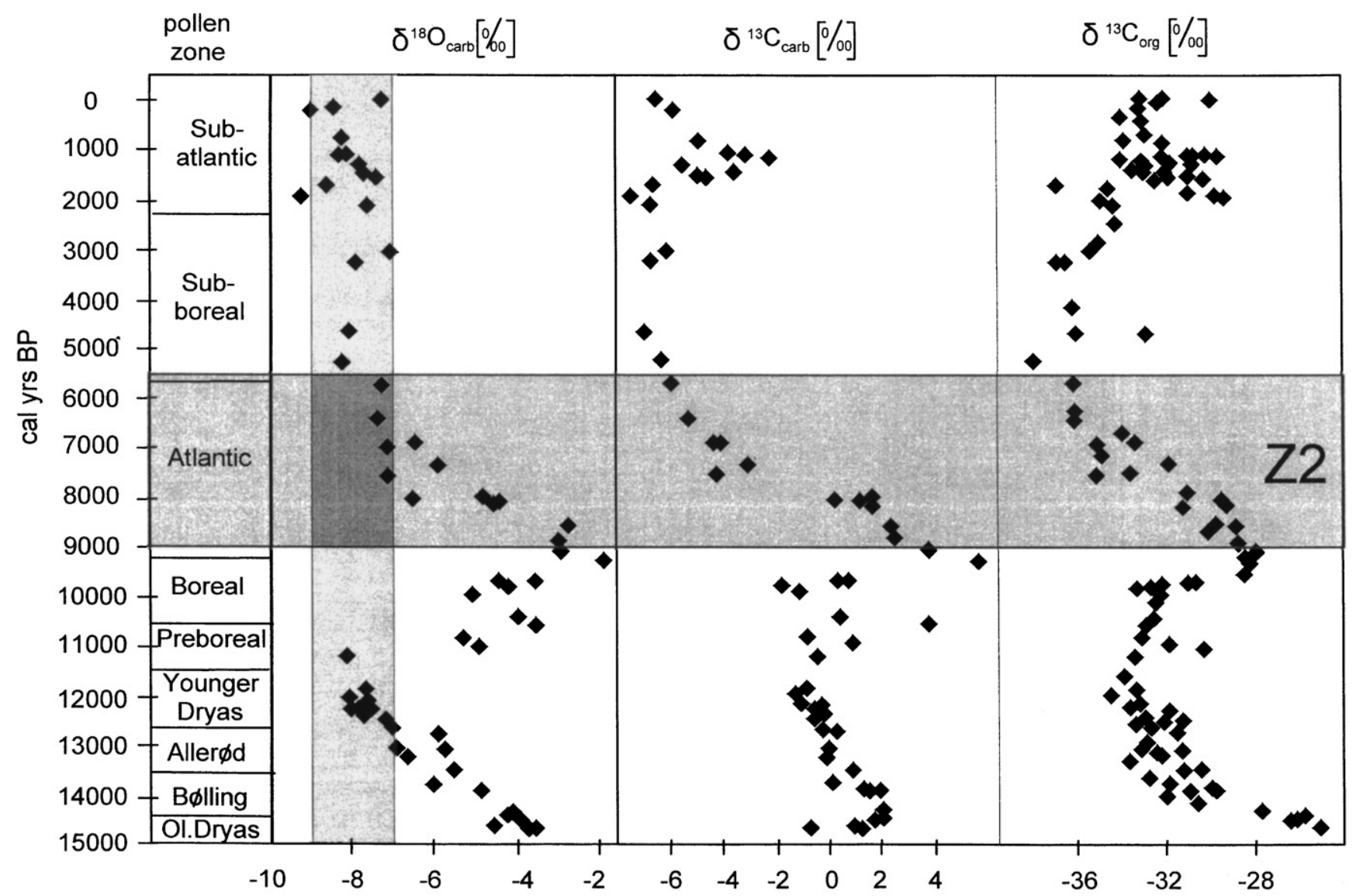

Fig. 24. $\delta^{18} \mathrm{O}$ and $\delta^{13} \mathrm{C}$ values of bulk carbonate, and $\delta^{13} \mathrm{C}$ values of bulk organic carbon vs. pollenzones and years cal $\mathrm{BP}$ in the sediments of Steißlinger See. The shaded vertical area indicates the expected range of $\delta^{18} \mathrm{O}_{\text {carb }}$ values for modern authigenic carbonates, if precipitated in equilibrium with the present day lake water. The shaded horizontal area indicates the period covered by time-slice II (Z2). (Mayer and Schwark, 1999, modified).

occur repeatedly during the cool periods of the Lateglacial. They result from occasional flooding of the lower parts of the cave after heavy rainfall which caused soil erosion. Clastic layers are absent or less frequent in the Preboreal and the Boreal but they have been found in speleothems during the Atlantic. The concentrations of trace elements are controlled by the residence time of the percolating water in the fissure system. High concentrations of $\mathrm{Mg}$, resulting from the low solubility of the host dolomite rock, point to a long residence time, whereas $\mathrm{Sr}$ and rare-earth elements (REE) increase with short residence times through increased rainfall. Clastic layers, and peaks of strontium and REEs occur contemporaneously in two stalagmite specimens, observations that indicate short-term wet phases during the Atlantic which is rather dry as a whole, especially during its lower part as also suggested by high extension rate.

In this context it is interesting to note that traces of erosion/redeposition were extremely scarce in lacustrine basins and in neither case could be attributed to increased or violent precipitation. This may be explained by the presence of a dense canopy of deciduous forest which attenuated the effect of heavy rainfall or, more likely, rainfall was rather evenly distributed throughout the year.

In summary, the presented investigations reveal a consistent picture of important palaeohydrological changes with fluctuations of varying amplitudes during the first half of the Holocene. This helps to broaden the scientific discussion on palaeoclimate in Germany which still focusses mainly on temperature changes, which is also the case in debates aimed at the general public.

The end of the Preboreal is characterised by the lowest lake-levels which dropped repeatedly over a period of 360 years to levels of 5-7 m below the modern level which in respect to modern fluctuations, is enormous. The Boreal is regarded with respect to all archives, as a period with increased precipitation and consistently high lake-levels. Lake-levels fell at the Boreal/Atlantic transition for a short time span by an amount that hardly exceeded $2.5 \mathrm{~m}$. The Atlantic was consistently warmer but several studies found shortterm set-backs in temperature. Low precipitation/lakelevels of moderate amplitudes occurred during the Early Atlantic. Drier conditions in southern and eastern 


\section{$\rightarrow$ perhydroisorenieratene $\quad-$ aryl isoprenoids}

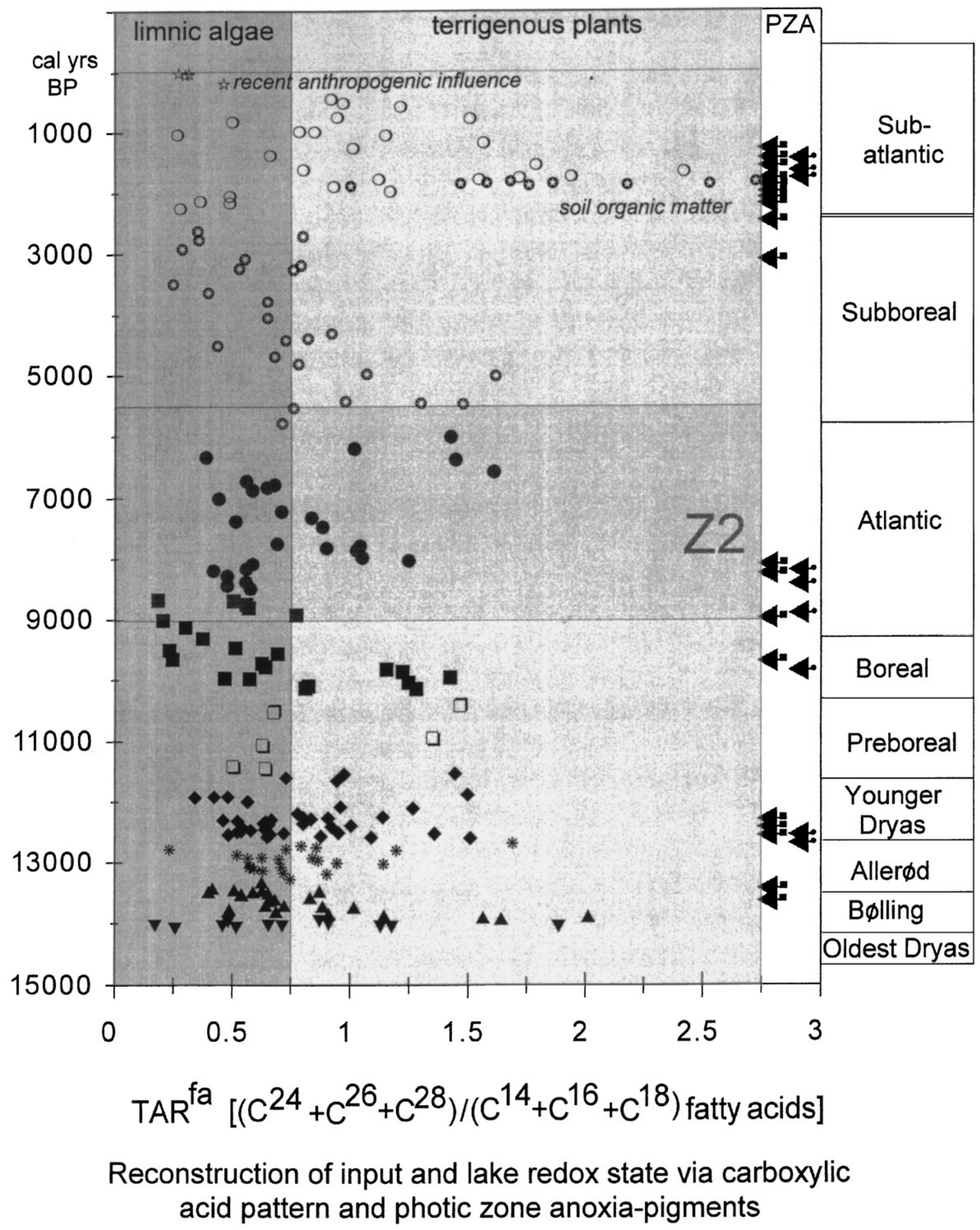

Fig. 25. Reconstruction of input and lake redox state via carboxylic acid pattern and photic zone anoxia pigments. Arrows at the right side: occurrence of sulfphur bacteria (Chlorobiaceae) indicating anoxia. Symbols inside denote the chronological position of the analysed sample, e.g. asterisk $=$ Alleroed, full circle $=$ Atlantic a.s.o. (Zink et al., 2000, modified).

Germany during this period are also indicated by the regional pattern of the primary forest (see Section 2.2). Wet conditions with higher lake-levels prevailed in all archives during the Late Atlantic. A final intermediate drop in lake-levels occurred near the transition Atlantic/ Subboreal.

It is obvious that the events detected in most of the archives cannot be dated with the precision necessary 
for more detailed interpretation. Difficulties with dating are even encountered in lacustrine sediments which are perhaps best suited for palaeohydrological studies, as lake-level changes are easy to detect in shallow waters but, are difficult to date accurately. Suitable proxies, are on the other hand, often not available in cores from the profundal zone of the lakes, where high resolution records and accurate dating are more easily achieved. Minor temporal offsets in different archives are therefore not suitable for assessing sensitivities of various lakes to drought, and using leads and lags to find causes and effects. An example is the mismatch of low lakelevel at 9250-9340 cal BP in the Hämelsee and glacier retreat in Switzerland at 9910-9550 cal BP (Fig. 23). Substantial progress in this respect is unlikely until a more precise time control is available. Meanwhile, it can be stated that the parallels between glacier advances and high lake-levels/moist periods as detailed in Magny (1998) and Haas et al. (1998) match roughly the results of the studies presented here, while the correspondence between the times of glacier retreat (Hormes et al., 2001) and low lake-levels in the Hämelsee is still closer.

\subsection{Seasonality}

Varves are seasonal laminations and therefore a sedimentary expression of cyclical seasonal changes providing information on the nature of the seasons. This information, however is modified by the complex lacustrine systems before being recorded in the sediment. The possibilities for interpretation are manifold, as has been demonstrated with studies carried out on sediments of Late Glacial age, around the transition to the Holocene (Merkt, 1994; Zolitschka, 1998; Merkt and Müller, 1999) and also during its older part (Brathauer et al., 2000), but can be ambiguous when complex interrelations are involved which is generally the case.

The microfabric and the internal succession (annual model based on seasonal sequence) of mid-Holocene varves is rather uniform in all the German lakes so far studied. Changes in thickness and varve quality are usually explained in terms of eutrophication or exposure to winds from changed tree vegetation and varying water depth as a result of lake-level fluctuations. These factors are not seasonal. Changes in the pattern of annual sequence or sub-elements of the varves pointing to changed characters of the seasons have not been observed. It is, however, noteworthy that many lakes preserved varved sediments during the climatic optimum. This not only points to favourable internal conditions of the lacustrine systems, but also to a particular seasonality supporting lamination during the Atlantic, as the sediments of many of these lakes are bioturbated before and after this period.
In the study of the Juessee sediments (Fig. 20), an attempt has been made to focus on seasonality by amalgamating sedimentological, geochemical, and biological data from the lake and its surroundings (Voigt et al., 2000). Summer warming began already in the Boreal. Milder and shorter winters occurred only 200 years later $(9500$ cal BP). This phase was possibly interrupted by a spell of cooler winters $(7500-8000 \mathrm{cal}$ BP) with a reversal to mesotrophic conditions, whereas summers had long periods of fine weather from $8400 \mathrm{cal}$ BP onwards as reflected by algal blooms and stabilised meromixis. Precipitation was characterised by frequent heavy rainfall until $8800 \mathrm{cal} \mathrm{BP}$, as inferred from clastic layers containing aerophilous diatoms. Rainfall was later more evenly distributed but it was moderate throughout the time slice and indicated a rather continental climate prevailing during the climate optimum. This multidisciplinary study leading to the assessment of seasonality is a valuable approach though not unambiguous.

Schönfelder and Steinberg (2000) and Schönfelder et al. (2000) applied similar multi-proxy considerations, mainly based on inferred limnochemical data and bioindications from diatom analyses of the sediments from the Großer Treppelsee. Long cold winters and evenly distributed low levels of precipitation prevailed during the Preboreal and the Boreal. Moderate warming especially during the summer prevailed in the early Holocene. Strong seasonality with stable, long stagnation periods and substantial circulation in the mild spring after clearly shorter winters were typical for the Atlantic, the younger part of which had intensive rainfall.

\subsection{Eutrophication}

Increased bioproduction following the Preboreal in the Juessee (Fig. 20, Voigt et al., 2000) is explained as resulting from the rise of summer temperatures, as there is no indication of increased supply of nutrients during this period. The trophic status, as inferred from diatoms, remains high during the Boreal and the first millennium of the Atlantic (with algal blooms), it becomes mesotrophic for a short period which is interpreted as being somewhat cooler $(8170-7500 \mathrm{cal} \mathrm{BP})$, after which there is an increase in the eutrophic status.

Schönfelder and Steinberg (1998) created a new diatom training set from 65 sites in Brandenburg (North Germany) with 284 significant species and developed transfer functions for the diatom-nutrient relation using statistical techniques. Inferred TN and TP concentrations in the Müggelsee indicated a rapid and stepwise eutrophication (Fig. 18) reaching modern levels as early as 7200 cal BP, which was exclusively ascribed to climatic factors, e.g. rising temperatures and substantially increased precipitation, leading to enhanced water 
flow in the river Spree, and therefore increased supply of nutrients. The slight rise in diatom-inferred TP concentration in the Großer Treppelsee (Schönfelder and Steinberg, 2000 and Fig. 19) indicates a mesotrophic situation during the Atlantic with seasonal eutrophic peaks in spring as inferred from specific diatom blooms.

Eutrophication has not been ascribed to human activity in any of the lakes studied in northern Germany. Even substantial increase in the concentration of charcoal during the final centuries of the time slice, suggesting human activity close to the lakes, does not seem to parallel any noticeable disturbances of the lacustrine systems or increase in their productivity.

Schwark et al. (submitted) used a geochemical approach to assess changing lacustrine eutrophication. Increased input of terrigenous plants into the Steißlinger See in conjunction with higher lake levels were parallelled and followed by an additional load of nutrients which in turn supported the growth of green sulphur bacteria (Chlorobiaceae), identified on the basis of pigments (arrows in Fig. 25). Thus, anoxic conditions at higher levels in the water column could be demonstrated using biomarkers.

Eutrophy is a prerequisite for organic production, and this in turn is a precondition for anoxia in the deeper water body (hypolimnion) of lakes. Anoxic hypolimnia are required to suppress bioturbation and guarantee the preservation of varves and/or the precipitation of siderite. Organic production during the entire Holocene was sufficient to establish anoxia when climatic conditions and basin morphologies were favourable. Varves and siderite are therefore indicative of at least a moderate trophic level, but are not suited for discrimination between different levels of eutrophy.

\subsection{Regionality}

Regional differentiation is visible at many sites and expressed in proxies. However, due to the multitude of interfering climatic, geographic, biologic and partly anthropogenic parameters it is generally not possible to unambiguously attribute discrete processes or causes to the observed features. The comparison of the forest composition at the Steißlinger See and the Schleinsee/ Degersee only $70 \mathrm{~km}$ apart from each other may serve as an example. The former, sheltered by the Black Forest, is in a warmer and much drier landscape (Hegau) than the latter. Neolithic man favoured the dry region and consequently used the forest intensively.

A stalagmite from the Hölloch, Bavarian Alps (Niggemann et al., 2000) with elevated extension rates from the Early Altlantic onwards and co-varying curves for $\delta^{13} \mathrm{C}$ and $\delta^{18} \mathrm{O}$ as in the $\mathrm{B} 7$ cave, show only minor isotopic oscillations on a medium level during the climatic optimum which is either due to the much higher elevation of the site ( $1445 \mathrm{~m}$ a.s.l.) or to a stable vegetation cover during this period.

The initial formation of mires in Bavaria, intercalated between gravel beds (Schneider, 2002), appears to be time transgressive (Fig. 22) as they seem to become younger from east to west. The migration of spruce is in the same direction during the Atlantic. However, it is not clear whether this temporal succession is due to the regional climate or to altitudinal differences as the western-most mire is $200 \mathrm{~m}$ higher.

The pattern of sedimentary development, resulting from lake-level oscillations during the Early Holocene, is remarkably similar in the Degersee and the shallow part of the Steißlinger See, southern Germany, and different from the Hämelsee in northern Germany. The lowest lake-levels detected in the early Holocene are roughly contemporary in northern and southern Germany. At first glance one might suspect that climatic factors could account for the differences, but, hydrological and geological factors in the catchment area may also control the sensitivity of the lakes in reacting to and displaying fluctuations in water levels. The results from these three lakes do not provide a good basis to make any definite conclusions.

Different patterns of lacustrine sediments, which are usually expected on a transect from western- to easternGermany, e.g. from a humid-oceanic to a more continental climate with less but more intense precipitation and stable accentuated summers and winters, were not found during the climatic optimum.

There are two exceptions to the ambiguous situation mentioned above. Firstly, the natural composition of the forest reflects differences that are due to regional climate and/or elevation, and also migration patterns (see Section 2.2). Secondly, the geological/pedological setting is another regional feature which unequivocally controls lacustrine sedimentology and, in part, human settlement.

The lakes situated in areas with limestones or inside the terminal moraines of the last glaciation, in northern and southern Germany, have the potential to produce calcareous deposits. The precipitation/preservation of calcite in the lakes of southern Germany show common features which vary gradually depending on the morphology (depth and size) of the lake basins. The deposits in the central part of most of the lakes have a high and uniform calcite concentration during the climatic optimum, whereas the sediments of the Boreal are poor in calcite and those of Preboreal age are largely devoid of it. The calcite content is lower and fluctuates frequently during the Subboreal. The interrelation between climatic forcing and internal lacustrine processes is still not understood. Within the above boundary conditions, the precipitation/preservation of calcite appears to be primarily, but not exclusively, controlled by climate in its broadest sense. These 
common features do not apply to northern German lakes of the same type.

Soils in non-limestone areas or with soils arising from older glaciations are deeply leached by pedogenic processes during the Eemian and the Late Glacial-Early Holocene, and are therefore devoid of calcite. The sediments in lake basins with catchments of Saalian age are non-calcareous in the Holocene. Iron is readily mobilised from these leached soils and transported into the lakes. Only minor amounts of pyrite are precipitated under anoxic conditions within the freshly deposited sediment as sulfphur is usually sparse in freshwater lakes. Siderite (iron carbonate) is precipitated at the mud/water interface under medium anoxic and neutral to basic conditions and almost independent from the trophic state. Sediments are formed which contain $10-15 \%$, sometimes up to $50 \%$ iron (Hämelsee, maar lakes in the Eifel).

\subsection{Human impact}

The possibility to detect the very first imprints of early human activity in the environment is very limited. Speleothems and mires are not prone to react to weak human influence. Lacustrine systems, however, give more sensitive archives.

No indication of erosion ascribable to human interference was recorded in the investigated lakes, mires or speleothems during the Atlantic. This absence of allochthonous input to lacustrine systems contrasts with evidence of human presence on the lake shores and of anthropogenically induced erosion and redeposition of flood loam (Auelehm) in fluvial environments in the Late Atlantic (Hiller et al., 1991). Hiller et al. (1991), however, stress the point that early Neolithic people was very particular about where they settled. Not all river valleys experienced accumulation of flood loam before the Bronze Age as relatively dry, preferentially loesscovered areas were favoured by the Bandkeramik. The Bindersee near Halle, central Germany, is in an area of this type and the calcareous sedimentation in the shallow lake is, from the mid-Atlantic onwards, frequently and increasingly interrupted by humic silt washed into the lake from the loess covered catchment (Litt, 1994; Kleinmann et al., in preparation). Additionally, the lack of redeposited sediments in many lakes may be partly explained by the fact that most lakes are cored in the profundal zone to obtain highly resolved records without hiatuses. Cores retrieved along transects show that sediments eroded from the shores are often redeposited on the sloping margins and do not reach the profundal parts of the basins.

Human impact is beyond any doubt first recorded towards the end of the time window discussed. Massive occurrences of charcoal, along with closed curves from pollen of cereals and ruderal plants connected with forest clearances and also the first sedimentological signals as clastic input and partly drastic changes in the carbonate content have been reported from the lakes studied. This major onset of late Neolithic human impact is, within the range of the error in varve-dating, amazingly contemporaneous in the Juessee (Voigt et al., 2000), Steißlinger See (Lechterbeck, 2000), Schleinsee and Degersee (Clark et al., 1989; Kleinmann et al., in preparation), in northern and southern Germany and dates to around 6300 cal BP. It is consistent with the decline of the first peak of Fagus in south-western Germany and Switzerland (Richoz et al. (1994) and Ammann (1989), whose age determinations made one decade ago were too young, as was the chronology in Clark et al. (1989). For the next six millennia there are unmistakeable signals of human settlement following each other in consecutive pulses (Ammann, 1989) of prehistoric cultures, as evidenced by artifacts and settlements. They are accompanied by charcoal, secondary forest cycles, and the increased input of erosional clastics and nutrients into the lakes. It is furthermore, most interesting that there are parallels between the occupation phases and low lake levels (Richoz et al., 1994).

The question arises as to whether there is any indication of human activity before 6300 cal BP, with or without direct proof of human presence near the lakes? Are we allowed to extend into the past the reasoning accepted for the period after 6300 cal BP, and what is the relevant evidence? Are there plausible parallels between human activity and natural variability?

Secondary forest cycles (see Section 2.2), existing as consecutive peaks of NAP, hazel, ash, lime, elm, oak, and after 6500 cal BP, beech, accompanied by fire are reported from the Schleinsee (Clark et al., 1989) and Degersee (Kleinmann et al., in preparation) with frequencies of 200-300 years from 8200 cal BP onwards. Fire signals are observed after 8850 cal BP. Cereal-type pollen are found from $8200 \mathrm{cal}$ BP onwards (Triticum/Hordeum: Schleinsee, Clark et al., 1989), 8000 cal BP (Degersee, Kleinmann et al., in prep.), $8800 \mathrm{cal}$ BP (Juessee, Voigt et al., 2000). Fire with increased magnitude and forest cycles occur later in the Schleinsee around 7400, 7200 and $6950 \mathrm{cal}$ BP. Lechterbeck (2000) argues for the first man-made forest disturbance at 7425 cal BP in the Steißlinger See. Apart from charcoal, neither compositional nor structural changes of the sediments deposited during the Bandkeramik culture and attributable to human impact have been found in any of the lakes mentioned above.

Secondary forest cycles, occurring in temporal distances of some centuries, constitute deep incisions in the forest. Especially the later examples point to an extensive and contemporary utilisation of land in the 
immediate vicinity of the lakes and also in the larger catchment areas. Migrating slash and burn cultures, occupying isolated patches in an otherwise forested landscape, are expected to give noisy pollen diagrams, but without the distinct patterns of secondary forest cycles which cannot be produced by continuous processes alone.

It is interesting to consider in this context that the Neolithic cultures are not presented as the result of evolving continua, but largely disappear and reappear with new cultural acquisitions, suggesting the breakdown and renewal of settlements. The causes of the pulsating occupation may be social in the broadest sense (this is beyond the scope of this paper), or environmental. Climatic changes, especially droughts, affect large areas at the same time, and hence are the probable agent to control man and the environment, e.g. by facilitating forest fire (Richoz et al., 1994).

A causal connection between lake-levels, droughts, glacier retreats and secondary forest cycles is still not proven, but it is a reasonable assumption. A climatic control of the presence and favouring of Neolithic people, who in turn produce secondary forest cycles that are favoured by drought, is increasingly plausible.

\section{Conclusion}

According to the results presented here, which refer to time slice II of the priority programme, the Holocene climatic optimum can be subdivided into three distinctive phases encompassing the intervals from 9000 to 7500 cal BP, the Mesolithic, ca 7500-6300 cal BP, the Early and Middle Neolithic, and the Younger Neolithic after $6300 \mathrm{cal} \mathrm{BP}$.

The first phase is characterised by stable environmental conditions. The investigated archives, except the speleothems, do not show consistent changes in palaeotemperature. This also applies to the following phases until the end of the climatic optimum. Compared with the preceding Boreal, low lake-levels occurred during the Early Atlantic, probably reflecting periods of decreased precipitation. In general, the sedimentary records indicate calm meteorological conditions. The pollen records suggest that the vegetation was in equilibrium and had already reached its interglacial climax stage. The plant cover resulted in soil stabilisation including sloping ground, so that only negligible accumulation of clastic sediments occurred in restricted areas on floodplains and in lakes. Although the presence of Mesolithic people is documented by archaeological finds and, at times, considerable amounts of charcoal fragments in lake sediments, evidence for major anthropogenic impact on the environment has not been detected.

In the second phase, during the Early and Middle Neolithic, particularly high lake levels provide evidence of a wetter climate, probably induced by increased precipitation. Pollen records from the lowlands of southern and central Germany show noticeable changes within the forest vegetation. The most striking are the so-called secondary forest cycles, indicating stepwise anthropogenic clearances in the Atlantic primeval forest. Human activity, however, hardly caused any changes in the deposition of colluvia, floodplain deposits or lake sediments. This indicates that Early Neolithic farming activities were enacted within the buffering capacities of the forest ecosystems on rich soils. Clearances were restricted to the minimum needed for arable farming and the woodlands were only manipulated in such a way that sufficient fodder for the livestock could be extracted. Therefore, in spite of the woodland clearances, Early Neolithic life seems to have remained strongly adapted to the forest ecosystem and evidently remained part of it.

While high lake-levels prevailed during the second phase of the climatic optimum, lake-levels fell for several centuries at ca $6300 \mathrm{cal} \mathrm{BP}$, the beginning of the third phase. Moreover, this was an important time marker in various respects: The pollen diagrams from southern Germany show large-scale woodland clearances, indicating substantial changes in land use from this time forward. Those from northern Germany show the adoption of agriculture by Mesolithic people. They all show a new approach by Neolithic farmers in dealing with the landscape. Previous Early and Middle Neolithic adaption to the forest ecosystem was abandoned during the Younger Neolithic in favour of an agricultural system exploiting the environment. The introduction of new agricultural technologies, e.g. ploughing, and new crops, also characterises this period.

Increased thickness of colluvia and the deposition of flood loam point to an increase of soil erosion with serious effects on the landscape. Remarkable changes in the composition and the fabric of lacustrine sediments, with a rising proportion of clastics and raised amounts of charcoal particles, also mirror more vigorous human impact on the environment, which may be amplified by the contribution of natural variables like droughts. It is tempting to relate the changes in the fluvial and lacustrine records to the newly introduced use of the plough. Ploughing led to destruction of soil texture, and thus facilitated soil erosion.

\section{Acknowledgements}

Our sincere thanks go to the leaders and the many coworkers of the projects presented here for providing 
papers, unpublished reports, data and valuable comments. Several also contributed figures that they prepared especially for this paper. While it is not possible to list all contributors, the authors wish to acknowledge the substantial contributions, including primary data, by the following: H.-J. Beug, W. Dörfler, E. Endtmann, K. Eusterhues, S. Hönscheidt, A. Kleinmann, B. Kubitz, A. Lang, J. Lechterbeck, H. Müller, S. Niggemann, S. Nolte, H. Reichardt, D. Richter, H. Rittweger, A. Schweizer, H. Schneider, T. Schneider, I. Schönfelder, L. Schwark, R. Voigt. The authors wish also to thank $\mathrm{Ch}$. Bendall and K. Bie who improved the English language. In addition, the authors are indebted to $\mathrm{M}$. O'Connell and an anonymous reviewer for providing critical and helpful comments and for linguistically amending the manuscript. The various investigations were funded by the Deutsche Forschungsgemeinschaft (DFG). The research was carried out as contribution to the interdisciplinary priority programme "Changes of the Geo-Biosphere during the last 15000 years continental sediments as evidence for changing environmental conditions". Most of the data presented here are available from the PANGAEA information system http://www.pangaea.de/Projects/GeoBio15k.

\section{References}

Aaby, B., 1986. Trees as anthropogenic indicators in regional pollen diagrams from Eastern Denmark. In: Behre, K.E. (Ed.), Anthropogenic Indicators in Pollen Diagrams. Balkema, Rotterdam/ Boston, p. 73-93.

Ammann, B., 1989. Late-Quaternary palynology at Lobsigersee. Regional vegetation history and local lake development. Dissertationes Botanicae 137, 157pp.

Andersen, S.T., 1988. Pollen spectra from the Double Passage-Grave, Klekkendehöj, on Mön - evidence of swidden cultivation in the Neolithic of Denmark. Journal of Danish Archaeology 7, 77-92.

Andres, W., Bos, J.A.A., Houben, P., Kalis, A.J., Nolte, S., Rittweger, H., Wunderlich, J., 2001. Environmental change and fluvial activity during the Younger Dryas in Central Germany. Quaternary International 79, 89-100.

Bakker, R., 2002. The emergence of agriculture on the Drenth plateau. A paleobotanical study supported by high resolution dating. Dissertation Groningen.

Barsch, D., Mäusbacher, R., Schukraft, G., Schulte, A., 1993. Die Änderungen des Naturraumpotentials im Jungneolithikum des nördlichen Kraichgaus dokumentiert in fluvialen Sedimenten. Zeitschrift für Geomorphologie N. F., Suppl. 93, 175-187.

Behre, K.-E., 1981. The interpretation of anthropogenic indicators in pollen diagrams. Pollen et Spores 23, 225-245.

Behre, K.-E., Jacomet, S., 1991. The ecological interpretation of archaeobotanical data. In: van Zeist, W., Wasylikowa, K., Behre, K.-E. (Eds.), Progress in Old World Palaeoethnobotany. A Retrospective View on the Occasion of 20 Years of the International Working Group for Palaeoethnobotany. Balkema, Rotterdam/Brookfield, pp. 81-108.

Behre, K.-E., Kučan, D., 1994. Die Geschichte der Kulturlandschaft und des Ackerbaus in der Siedlungskammer Flögeln, Niedersachsen, seit der Jungsteinzeit. Probleme der Küstenforschung 21, $227 \mathrm{pp}$.
Berglund, B.E., Hjelmroos, M., Kolstrup, E., 1991. The Köpinge area — vegetation and landscape through time. In: B.E. Berglund (Ed.), The Cultural Landscape during 6000 years in Southern Sweden the Ystad Project. Ecological Bulletin 41, 109-112.

Beug, H.-J., 1961. Leitfaden der Pollenbestimmung für Mitteleuropa und angrenzende Gebiete. Fischer, Stuttgart, 65pp.

Beug, H.-J., 1992. Vegetationsgeschichtliche Untersuchungen über die Besiedlung im Unteren Eichsfeld, Landkreis Göttingen, vom frühen Neolithikum bis zum Mittelalter. Neue Ausgrabungen und Forschungen in Niedersachsen 20, 261-339.

Beug, H.-J., Henrion, I., Schmüser, A., 1999. Landschaftsgeschichte im Hochharz. Die Entwicklung der Wälder und Moore seit dem Ende der letzten Eiszeit. 454 S., 220 Abb., 67 Tab., 1 Kt. 1:25000, Papierflieger Verlag, Clausthal - Zellerfeld.

Blum, M.D., Törnqvist, T.E., 2000. Fluvial responses to climate and sea-level change: a review and look forward. Sedimentology 47, Suppl. 1, 2-48.

Bork, H.R., 1983. Die holozäne Relief- und Bodenentwicklung in Lössgebieten. Beispiele aus dem südöstlichen Niedersachsen. In: Bork, H.R., Ricken, W. (Eds.), Bodenerosion, Holozäne und Pleistozäne Bodenentwicklung. Catena Supplement 3, 1-93.

Bos, J.A.A., Urz, R., 2002. Local impact of Early Mesolithic man on the environment in the middle Lahn river valley (Hessen), centralwest Germany - pollen and macrofossil evidence. Vegetation History and Archaeobotany 21.

Bottema, S., 1988. Back to Nature? Objectives of nature managment in view of archaeological research. In: Bierma, J.H., Harsema, O.H., Zeist, W. van (Eds.), Archaeologie en Landschap. BiologischArchaeologisch Instituut Groningen, pp. 185-205.

Brathauer, U., Brauer, A., Negendank, J.F.W., Zolitschka, B., 2000. Rasche Klimaänderungen am Beginn der heutigen Warmzeit. Zweijahresbericht, GeoForschungsZentrum Potsdam, 1998/1999, 29-33, 6 Abb., Potsdam.

Brinkkemper, O., Hogestijn, W.-J., Peeters, H., Visser, D., Whitton, C., 1999. The early Neolithic site at Hoge Vaart, Almere, the Netherlands, with particular reference to non-diffusion of crop plants, and the significance of site function and sample location. Vegetation History and Archaeobotany 8, 79-86.

Bubenzer, O., 2000. Sedimentologische und Gerinnegeomorphologische Befunde im Einzugsgebiet der Schwülme (Südniedersachsen) zur Rekonstruktion der Spätglazialen bis Mittelholozänen Morphodynamik. Zeitschrift für Geomorphologie N. F., Suppl. 121, 23-44.

Castelletti, L., Stäuble, H., 1997. Holzkohlenuntersuchungen zu urund frühgeschichtlichen Siedlungen der Aldenhovener Platte und ihrer Umgebung (Niederrheinische Bucht). In: Lüning, J. (Ed.), Studien zur neolithischen Besiedlung der Aldenhovener Platte und ihrer Umgebung. Beiträge zur Neolithischen Besiedlung der Aldenhovener Platte, 6. Rheinische Ausgrabungen 43, 685-714.

Clark, J.S., Merkt, J., Müller, H., 1989. Post-glacial fire, vegetation, and human history on the northern Alpine forelands, southwestern Germany. Journal of Ecology 77, 897-925.

Dambeck, R., Sabel, K.-J., 2001. Spät- und postglazialer Wandel der Flusslandschaft am nördlichen Oberrhein und Altneckar im Hessischen Ried. Jahresberichte und Mitteilungen des Oberrheinischen Geologischen Vereins N. F. 83, 131-143.

Dambeck, R., Thiemeyer, H., 2002. Fluvial history of the northern Upper Rhine river (south-western Germany) during the Lateglacial and Holocene times. Quaternary International 93-94, 53-63.

Dengler, A., 1935. Waldbau auf ökologischer Grundlage. Berlin.

Dieckmann, B., Maier, U., Vogt, R., 2002. Hornstaad, zur inneren Dynamik einer jungsteinzeitlichen Dorfanlage am westlichen Bodensee. Neue Ergebnisse der Archäologie, Botanik und Bodenkunde. In: Lippert, A., Schultz, M., Shennan, S., TeschlerNicola, M. (Eds.), Mensch und Umwelt im Neolithikum und der Frühbronzezeit in Mitteleuropa. Ergebnisse interdisziplinärer 
Zusammenarbeit zwischen Archäologie, Klimatologie, Biologie und Medizin. Fortschritte in Paläopathologie und Osteoarchäologie 3,

Dörfler, W., 2001. Von der Parklandschaft zum Landschaftspark. Rekonstruktion der neolithischen Landschaft anhand von Pollenanalysen aus Schleswig-Holstein. In: Kelm, R. (Ed.), Zurück zur Steinzeitlandschaft. Archäologische und ökologische Forschung zur jungsteinzeitlichen Kulturlandschaft und ihrer Nutzung in Nordwestdeutschland. Albersdorfer Forschungen zur Archäologie und Umweltgeschichte 2, 39-55.

Eberhardt, E., 1998. Mikromorphologische Untersuchungen zur Genese des "Schwarzen Auenbodens" im Bereich des Amöneburger Beckens (Hessen). Diploma Thesis, FB Geographie, Universität Marburg, $119 \mathrm{pp}$.

Eusterhues, K., 2000. Die Sedimente des Steißlinger Sees (Hegau, Süddeutschland) - Ein Archiv für zeitlich hochaufgelöste geochemische Untersuchungen zu Umweltveränderungen im Holozän. Dissertation on CD-Rom, Universität Göttingen.

Eusterhues, K., Lechterbeck J., Schneider, J., Wolf-Brozio, U. in press. Late- and Postglacial evolution of Lake Steisslingen (I). Sedimentary history, palynological record and inorganic geochemical indicators. Palaeogeography, Palaeoclimatology Palaeoecology.

Fægri, K., Iversen, J., 1989. Textbook of Pollen Analysis. Wiley, Chichester, New York, Brisbane, Toronto, Singapore, 328pp.

Fischer-Zujkov, U., 2000. Die Schwarzerden Nordostdeutschlands ihre Stellung und Entwicklung im holozänen Landschaftswandel. Thesis, Humboldt-Universität Berlin, 173 pp (http://dochost.rz.huberlin.de/dissertationen/fischer-zujkov-ute-2000-12-05/).

Friedmann, A., 1999. Die spät- und postglaziale Landschafts- und Vegetationsgeschichte des südlichen Oberrheintieflands und Schwarzwalds. Habilitationsschrift der Geowissenschaftlichen Fakultät der Albert-Ludwigs-Universität Freiburg i. Br., $231 \mathrm{pp}$.

Gaillard, M.-J., Birks, H.J.B., Ihse, M, Runborg, S., 1998. Pollen/ landscape calibrations based on modern pollen assemblages from surface-sediment samples and landscape mapping - a pilot study in South Sweden. In: Gaillard, M.-J., Berglund, B.E. (Eds.), Quantification of Land Surfaces Cleared of Forest during the Holocene - Modern Pollen/Vegetation/Landscape Relationships as an Aid to the Interpretation of Fossil Pollen Data. Paläoklimaforschung 27, 31-52.

Glass, M., 1991. Animal production systems in Neolithic central Europe. BAR, International Series 572, Oxford.

Groenman-van Waateringe, W., 1971. Hecken im westeuropäischen Frühneolithikum. Berichte van de Rijksdienst voor Oudheidkundig Bodemonderzoek 20-21, 295-299.

Haas, J.N., Richoz, I., Tinner, W., Wick, L., 1998. Synchronous holocene climatic oscillations recorded on the Swiss Plateau and at timberline in the Alps. The Holocene 8 (3), 301-309.

Hartz, S., Hoffmann-Wieck, G., 2000. Küstenbesiedlung und Landschaftsentwicklung im 5. Jahrtausend v.Chr. am Beispiel des Oldenburger Grabens in Ostholstein. In: Kelm, R. (Ed.), Vom Pfostenloch zum Steinzeithaus. Archäologische Forschung und Rekonstruktion jungsteinzeitlicher Haus- und Siedlungsbefunde im nordwestlichen Mitteleuropa. Albersdorfer Forschungen zur Archäologie und Umweltgeschichte 1, 70-87.

Hartz, S., Heinrich, D., Lübke, H., 2000. Frühe Bauern an der Küste. Neue ${ }^{14} \mathrm{C}$-daten und aktuelle Aspekte zum Neolithisierungsprozeß im norddeutschen Ostseeküstengebiet. Prähistorische Zeitschrift 75 (2), 129-152.

Hicks, S., 1998. Fields, boreal forests and forest clearings as recorded by modern pollen deposition. In: Gaillard, M.-J., Berglund, B.E. (Ed.), Quantification of Land Surfaces Cleared of Forest during the Holocene - Modern Pollen/Vegetation/Landscape Relationships as an Aid to the Interpretation of Fossil Pollen Data. Paläoklimaforschung 27, 53-66.
Hiller, A., Litt, Th., Eissmann, L., 1991. Zur Entwicklung der Jungquartären Tieflandstäler im Saale-Elbe-Raum unter Besonderer Berücksichtigung von ${ }^{14} \mathrm{C}$-Daten. Eiszeitalter und Gegenwart 41, 26-46.

Hoika, J., 1987. Das Mittelneolithikum zur Zeit der Trichterbecherkultur in Nordostholstein. Untersuchungen zur Archäologie und Landschaftsgeschichte. Offa-Bücher 61.

Hoika, J., 2000. Grenzfragen oder: James Watt und die Neolithisierung. In: Kelm, R. (Ed.), Vom Pfostenloch zum Steinzeithaus. Archäologische Forschung und Rekonstruktion jungsteinzeitlicher Haus- und Siedlungsbefunde im nordwestlichen Mitteleuropa. Albersdorfer Forschungen zur Archäologie und Umweltgeschichte 1, 53-69.

Hormes, A., Müller, B.U., Schlüchter, C., 2001. The Alps with little ice: evidence for eight Holocene phases of reduced glacier extent in the Central Swiss Alps. The Holocene 11 (3), 255-265.

Houben, P., 1997. Late-glacial and Holocene fluvial sedimentation in a small upland catchment in Hesse (Germany). Zeitschrift für Geomorphologie N. F. 41, 461-478.

Houben, P., Nolte, S., Rittweger, H., Wunderlich, J., 2001. Lateglacial and Holocene environmental change indicated by fluvial deposits of the Hessian Depression (Central Germany). In: Maddy, D., Macklin, M.G., Woodward, J.C. (Eds.), River Basin Sediment Systems - Archives of Environmental Change. Balkema, Rotterdam, pp. 249-264.

Iversen, J., 1949. Landnam i Danmarks stenalder (Land occupation in Denmark's Stone Age). Danmarks geologiske undersögelse II (66), $68 \mathrm{pp}$.

Iversen, J., 1973. The development of Denmark's Nature since the Last Glacial. Danmarks geologiske undersögelse V (7c), 126pp.

Iverson, J., 1949. The influence of prehistornic man on vegetation. Danmarks geologiske undersögelse IV R, 3, 6, 5-25.

Jacomet, S., Brombacher, C., Dick, M., 1989. Archäobotanik am Zürichsee. Ackerbau, Sammelwirtschaft und Umwelt von neolithischen und bronzezeitlichen Seeufersiedlungen im Raum Zürich. Ergebnisse von Untersuchungen pflanzlicher Makroreste der Jahre 1979-1987. Berichte der Zürcher Denkmalpflege Monographien 7, $348 \mathrm{pp}$.

Jakobsen, O., Hoffmann-Wieck, G., Thiede, J., 2001. Neue Ergebnisse der geoarchäologischen Forschung in der westlichen OldenburgerGraben-Niederung: Rekonstruktion der frühneolithischen Landschaft. In: Kelm, R. (Ed.), Zurück zur Steinzeitlandschaft. Archäologische und ökologische Forschung zur jungsteinzeitlichen Kulturlandschaft und ihrer Nutzung in Nordwestdeutschland. Albersdorfer Forschungen zur Archäologie und Umweltgeschichte 2, 89-95.

Jerz, H., Schneider, Th., Krause, K.-H., 2000. Zur Entwicklung der Schwemmfächer und Schwemmkegel in Randbereichen des Murnauer Mooses: mit Ergebnissen der GLA-Forschungsbohrungen bei Grafenaschau und Eschenlohe. Geologica Bavarica 105, 253-266.

Kalis, A.J., 1980. Papaveraceae. In: Punt, W., Clarke, G.C.S. (Eds.), The Northwest European Pollen Flora, Vol. 2, pp. 209-260. Elsevier.

Kalis, A.J., 1988. Zur Umwelt des frühneolithischen Menschen: ein Beitrag der Pollenanalyse. Forschungen und Berichte zur Ur- u. Frühgeschichte in Baden-Württemberg 31, 125-138.

Kalis, A.J., Meurers-Balke, J., 1997. Landnutzung im Neolithikum. In: Richter, J. Neolithikum. Geschichtlicher Atlas der Rheinlande, Beihefte II/2.1-II/2.2, 25-55.

Kalis, A.J., Meurers-Balke, J., 1998. Die Landnam"-Modelle von Iversen und Troels-Smith zur Neolithisierung des Westlichen Ostseegebeites - ein versuch ihrer aktualisierung. Prähistorische Zeitschrift 73, 1-24.

Kalis, A.J., Zimmermann, A., 1988. An integrative model for the use of different landscapes in Linearbandceramic times. In: Bintliff, 
J.L., Davidson, D.A., Grant, E.G. (Eds.), Conceptual Issues in Environmental Archaeology. University press Edinburgh, pp. 145-152.

Kalis, A.J., Meurers-Balke, J., van der Borg, K., von der Driesch, A., Rähle, W., Tegtmeier, U., Thiemeyer, H., 2001. Der La-HoguetteFundhorizont in der Wilhelma von Stuttgart-Bad Cannstatt. Anthrakologische, archäopalynologische, bodenkundliche, malakozoologische, radiometrische und säugetierkundliche Untersuchungen. In: Gehlen, B., Heinen, M., Tilmann, A. (Eds.), ZeitRäume - Gedenkschrift für Wolfgang Taute. Archäologische Berichte 14, 649-672.

Kleinmann, A., Merkt, J., Müller, H., 1997. Lake level fluctuations in the uppermost Preboreal in Lake Hämelsee. Seventh International Symposium on Palaeolimnology, Abstract Volume, Würzburger Geographische Manuskripte 41, 107-108.

Kleinmann, A., Merkt, J., Müller, H., 2000. Climatic lake-level changes in German lakes during the Holocene? Terra Nostra 2000/ 7, 55-63, Potsdam.

Kleinmann, A., Litt, T., Merkt, J., Müller, H. in preparation. Sedimentology, Vegetation History and Geochemistry of the Bindersee.

Kleinmann, A., Merkt, J., Müller, H. in preparation. Sedimentology, Vegetation History and Geochemistry of the Degersee.

Knörzer, K.H., 1971. Urgeschichtliche Unkräuter im Rheinland. Ein Beitrag zur Entstehung der Segetalgesellschaften. Vegetatio 23, 89-111.

Knörzer, K.H., 1986. Vom neolithischen Ackerbau in Rheinland. Archäologie in Deutschland. 1986 (1), 32-37.

Knörzer, K.H., 1988. Zur Auswertung von Wildpflanzenfunden aus dem Neolithikum des Rheinlandes. Archaeologische Informationen 11 (1), 20-32.

Körber-Grohne, U., 1990. Gramineen und Grünlandvegetation vom Neolithikum bis zum Mittelalter in Mitteleuropa. Bibliotheca Botanica 139.

Kreuz, A., 1990. Die erste Bauern Mitteleuropas. Eine archaeobotanische Untersuchung zu Umwelt und Landwirtschaft der ältesten Bandkeramik. Analecta Prehistoria Leidensia 23, 256pp.

Kubitz, B., 2000. Die Holozäne Vegetations- und Siedlungsgeschichte in der Westeifel am Beispiel eines Hochauflösenden Pollendiagrammes aus dem Meerfelder Maar. Dissertationes Botanicae 339, $106 \mathrm{pp}$.

Küster, H., 1991. Mitteleuropa südlich der Donau, einschließlich Alpenraum. In: W. van Zeist, K. Wasylikowa, K.E. Behre (Eds.), Progress in Old World Palaeoethnobotany. A Retrospective View on the Occasion of 20 Years of the International Working Group for Palaeoethnobotany. Balkema, Rotterdam/Brookfield, pp. 179-187.

Lang, A., Hönscheidt, S., 1999. Age and source of soil erosion derived colluvial sediments at Vaihingen-Enz, Germany. Catena 38/2, 89-107.

Lanting, J.N., Van der Plicht, J., 2000. De 14C-chronologie van de nederlandse pre- en protohistorie. III. Neolithikum. Palaeohistoria $41 / 42,1-110$

Lechterbeck, J., 2000. "Human Impact" oder "Climate Change"'? Zur Vegetationsgeschichte des Spätglazials und Holozäns in hochauflösenden Pollenanalysen laminierter Sedimente des Steißlinger Sees (Südwestdeutschland). Dissertation on CD-Rom, Univ. Tübingen.

Litt, Th., 1988. Stratigraphische Belege für Anthropogen Ausgelöste Bodenverlagerung vom Neolithikum bis zur Frühen Eisenzeit im Circumhercynen Raum. Ethnographisch-Archäologische Zeitschrift 29, 129-137.

Litt, Th., 1992a. Investigations on the extent of the early Neolithic settlement in the Elbe-Saale region and on its influence on the natural environment. In: Frenzel, B. (Ed.), Evaluation of Land Surfaces Cleared from Forest by Prehistoric Man in Early Neolithic Times and the Times of Migrating German Tribes; Paläoklimaforschung 8, 83-91.
Litt, Th., 1992b. Fresh investigations into the natural and anthropogenically influenced vegetation of the earlier Holocene in the Elbe-Saale Region, central Germany. Vegetation History and Archaeobotany 1, 69-74.

Litt, Th., 1994. Bindersee, 146-150 In: Paläoökologie, Paläobotanik und Stratigraphie des Jungquartärs im nordmitteleuropäischen Tiefland. Unter besonderer Berücksichtigung des Elbe-SaaleGebietes. Dissertationes Botanicae (Berlin) 227, 185 pp.

Litt, Th., 2003. Environmental response to climatic and human impact in central Europe during the last 15000 years — a German contribution to PAGES-PEP III. Quaternary Science Reviews, this issue (PII: S0277-3791(02)00178-6).

Litt, Th., Schmincke, H.U., Kromer, B., 2003. Environmental response to climatic and volcanic events in central Europe during the Weichselian Lateglacial. Quaternary Science Reviews, this issue (PII: S0277-3791(02)00180-4).

Löhr, H., 1986. Eine Übersichtskarte zun älteren Neolithikum im Moselgebiet. Archäologisches Korrespondenzblatt 16, 267-278.

Lüning, J., 1982. Siedlung und Siedlungslandschaft in bandkeramischer und Rössener Zeit. Offa 39, 9-33.

Lüning, J., 1988. Frühe Bauern in Mitteleuropa im 6. and 5. v. Chr. Jahrbuch des Römisch-Germanischen Zentralmuseums Mainz 35, 27-93.

Lüning, J., 1996. Erneute Gedanken zur Benennung der neolithischen Perioden. Germania 67, 233-237.

Lüning, J., 1997. Haus, Hof and Siedlung im Älteren Neolinthikum am Beispiel der Aldenhovener Platte in der Niederrheinische Bucht. In: Beck, H., Steuer, H. (Eds.), Haus und Hof in Ur- und frühgeschichtlicher Zeit. Göttingen, pp. 70-85.

Lüning, J., 2000. Steinzeitliche Bauern in Deutschland. Die Landwirtschaft im Neolithikum. Universitätsforschungen zur prähistorischen Archäologie 58, 285pp.

Lüning, J., Kalis, A.J., 1992. The influence of Early Neolithic settlers on the vegetation of the Lower Rhinelands and the determination of cleared areas based on archaeological and palynological criteria. In: Frenzel, B. (Ed.), Evaluation of Land Surfaces cleared from Forest by Prehistoric Man in Early Neolithic Times and the Time of Migrating Germanic Tribes. Paläoklimaforschung 8, $41-46$.

Lüning, J., Kloos, U., Albert, S., 1989. Westliche Nachbarn der Bandkeramischen Kultur: la Hoguette und Limburg. Germania 67, 355-393.

Mäckel, R., 1969. Untersuchungen zur jungquartären Flußgeschichte der Lahn in der Gießener Talweitung. Eiszeitalter u. Gegenwart 20, 138-174.

Mäckel, R., 1970. Die Entwicklung des Gießener Lahntales im Spätund Postglazial Berichte der Oberhessischen Gesellschaft für Natur- und Heilkunde N.F. Naturwissenschaftliche Abteilung 37, 45-68.

Mäckel, R., Friedmann, A., 1999. Holozäner Landschaftswandel im südlichen Oberrheintiefland und Schwarzwald. Eiszeitalter und Gegenwart 49, 1-20.

Macklin, M.G., Lewin, J., 1993. Holocene river alluviation in Britain. Zeitschrift für Geomorphologie N. F. 88, 109-122.

Magny, M., 1998. Reconstruction of Holocene lake-level changes in the French Jura: methods and results. In: Frenzel, B. (Ed.), Palaeohydrology as Reflected in Lake-level Changes as Climatic Evidence for Holocene Times. G. Fischer-Verlag, Stuttgart, pp. $67-85$.

Maier, U., 1996. Morphological studies of free-threshing wheat ears from a Neolithic site in Southwest Germany, and the history of the naked wheats. Vegetation History and Archaeobotany 5, $39-55$.

Maier, U., 2002. Archäobotanische Untersuchungen in HornstaadHörnle IA. Mit Beiträgen von Matthias Ahrens und Richard Vogt. Siedlungsarchäologie im Alpenvorland 6. 
Mäusbacher, R., Schneider, H., Igl, M., 2001. Influence of late glacial climate changes on sediment transport in the River Werra (Thuringia, Germany). Quaternary International 79, 101-109.

Mayer, B., Schwark, L., 1999. A 15000 -year stable isotope record from sediments of Lake Steisslingen, Southwest Germany. Chemical Geology 161, 315-337.

Merkt, J., 1994. The Allerød - duration and climate as derived from laminated lake sediments. Terra Nostra 1/94, Bonn, pp. 59-63.

Merkt, J., Müller, H., 1999. Varve chronology and palynology of the Lateglacial in Northwest Germany from lacustrine sediments of Hämelsee in Lower Saxony. Quaternary International 61, 41-59.

Meyer, M., 2000. Ein Hausgrundriss aus der latène- und kaiserzeitlichen Siedlung Mardorf 23, Kr. Marburg-Biedenkopf. Berichte der Kommission für Archäologische Landesforschung in Hessen 5, 115-121.

Müller, H., 1953. Zur spät- und nacheiszeitlichen Vegetationsgeschichte des mitteldeutschen Trockengebietes. Nova Acta Leopoldina, N.F. 16 (1 110$), 67 p p$.

Müller, H., 1962. Pollenanalytische Untersuchung eines Quartärprofils durch die spät- und nacheiszeitlichen Ablagerungen des Schleinsees (Südwestdeutschland). Geologisches Jahrbuch (Hannover) 79, 493-526.

Niggemann, S., Frank, N., Mangini, A., Richter, D.K., Wurth, G., 2000. Holozäne Stalagmiten des Sauerlandes (Deutschland) als Klimaarchive. Mitteilungen des Verbandes deutscher Höhlen- u. Karstforscher (München) 46/1/2, 84-90.

Niggemann, S., Mangini, A., Richter, D.K., Wurth, G., 2003 A palaeoclimate record of the last 17600 years in stalagmites from the B7 cave, Sauerland, Germany. Quaternary Science Review, in press.

Niller, H.-P., 1998. Prähistorische Landschaften im Lößgebiet bei Regensburg-Kolluvien, Auenlehme und Böden als Archive der Paläoumwelt. Regensburger Geographische Schriften 31, $1-429$.

Nolte, S., 2000. Auensedimente der Wetter als Indikatoren für die spätglaziale und holozäne fluviale Morphodynamik in der nördlichen Wetterau, Hessen. Shaker, Aachen, 206 pp.

O'Connell, M., 1987. Early cereal-type pollen records from Connemara, western Ireland and their possible significance. Pollen et Spores 29, 207-224.

Pott, R., 2000. Die Entwicklung der Europäischen Buchenwälder in der Nacheiszeit. Rundgespräche der Kommission für Ökologie 18, 49-75.

Pott, R., Hüppe, J., 1991. Die Hudelandschaften Nordwestdeutschlands. Abhandlungen des Westfälischen Museums für Naturkunde $53(1 / 2), 1-314$.

Punt, W., Den Breejen, P., 1981. Linaceae. In: Punt, W., Clarke, G.C.S. (Eds.), The North west European Pollen Flora, Vol. 3, pp. 75-115. Elsevier.

Raemaekers, D.C.M., 1999. The articulation of a "New Neolithic". The meaning of the Swifterbant culture for the process of neolithisation in the western part of the North European Plain (4900-3400 BC). Archaeological Studies 3, 224pp.

Richoz, I., Gaillard, M.-J., Magny, M., 1994. The influence of human activities and climate an the development of vegetation at Seedorf, Southern Swiss Plateau during the Holocene: a case study. In: Lotter, A.F., Ammann, B. (Eds.), Festschrift Gerhard Lang. Dissertationes Botanicae 234, 423-445.

Rittweger, H., 1997. Spätquartäre Sedimente im Amöneburger Becken - Archive der Umweltgeschichte einer mittelhessischen Altsiedellandschaft. Materialien zur Vor- und Frühgeschichte Hessens 20, $1-242$.

Rittweger, H., 1999. Eine boreale-subboreale Molluskensukzession als Spiegel der Vegetationsgeschichte in der Ohmniederung bei Marburg/Lahn. Frankfurter geowissenschaftliche Arbeiten D 24, 197-220.
Rittweger, H., 2000. The "Black Floodplain Soil" in the Amöneburger Becken, Germany: a lower Holocene marker horizon and indicator of an upper Atlantic and Subboreal dry period in Central Europe. Catena (Special Issue) 41, 143-164.

Rösch, M., 1990. Vegetationsgeschichtliche Untersuchungen am Durchenbergried. Forschungen und Berichte zur Ur- und Frühgeschichte in Baden-Württemberg 37, 9-56.

Rösch, M., 1993. Prehistoric land use as recorded in a lake-shore core at Lake Constance. Vegetation History and Archaeobotany 2, 213-232.

Schade, C., 2001. Landschaftsarchäologie in der Mörlener Bucht: Zentralität und Rohstoffvorkommen - Ein bandkeramischer Zentralort mit Nebensiedlungen in der Gemarkung von Butzbach-Fauerbach v.d.H. Berichte der Kommission für Archäologische Landesforschung in Hessen 6, 9-30.

Schellmann, G., 1998. Spätglaziale und holozäne Bodenentwicklung in einigen mitteleuropäischen Tälern unter dem Einfluß sich ändernder Umweltbedingungen. GeoArchaeoRhein 2, 183-193.

Schlichtherle, H., 1991. Aspekte der siedlungsarchäologischen Erforschung von Neolithikum und Bronzezeit im südwestdeutschen Alpenvorland. Berichte der Römisch-Germanische Kommission 71, 208-244.

Schmidt, H., in preparation Gastropodenfaunenanalysen und Faziesinterpretation an den spät- bis postglazialen Litoralsedimenten des Steißlinger Sees, Hegau. Diplom-Arbeit, Univ. Tübingen, unpublished.

Schmidt, B., Höfs, E., Khalessi, M., Schemainda, P., 1998. Dendrochronologische Befunde zur Datierung des Brunnens von ErkelenzKückhoven in das Jahr 5090 vor Christus. In: Koschik, H. (Ed.), Brunnen der Jungsteinzeit. Materialien zur Bodendenkmalpflege im Rheinland 11, 279-289.

Schneider, H., 2002a. Die spät- und postglaziale Vegetationsgeschichte des oberen und mittleren Werratals - paläobotanische Untersuchungen unter besonderer Berücksichtigung anthropogener Einflüsse. Dissertation Friedrich Schiller-Universität Jena.

Schneider, Th., 2002b. The development of alluvial cones and bogs along the northern border of the Alps - the Murnauer Moos in Upper Bavaria. Zeitschrift für Geomorphologie N.F. Suppl., in preparation.

Schönfelder, I., Steinberg, C.E.W., 1998. Paläolimnologische Analyse fluviatiler Sedimente der Spree. Final report DFG, 35 pp., Berlin.

Schönfelder, I., Steinberg, C.E.W., 2000. Quantitative Rekonstruction klimatisch bedingter Umweltveränderungen im Spätglazial und Holozän in Sedimenten der Schlaube durch Diatomeenanalysen. Final report DFG, 46pp.

Schönfelder, I., Giesecke, T.H., Gelbrecht, J., Steinberg, C.E.W., 2000. Paleolimnological investigations on Late Glacial and Holocene sediments of lake Großer Treppelsee (Brandenburg). Berichte des IGB 10, 171-184.

Schulte, A., Stumböck, M., 2000. Sedimentologische Befunde für den neolithischen und bronzezeitlichen Landschaftswandel im Hegau, SW-Deutschland - Erste Ergebnisse. Zeitschrift für Geomorphologie N.F., Suppl. 121, 151-169.

Schwabedissen, H., 1980. Ertebölle/Ellerbek - Mesolithikum oder Neolithikum? Veröffentlichungen des Museums für Vor- u. Frühgeschichte in Potsdam 14/15, 129-142.

Schwark, L., Zink, K-G., Lechterbeck, J., Leythaeuser, D., Mayer, B. submitted. Postglacial evolution of Lake Steisslingen II-variations in geochemical composition of laminated sediments induced by postglacial climatic and anthropogenic processes.Palaeogeography, Palaeoclimatology, Palaeoecology.

Schwark, L., Zink., K-G., Lechterbeck, J. submitted. Distribution of long-chain n-alkanes as a tool for reconstruction of postglacial vegetation development-linking the geochemical, the palynological record. Organic Geochemistry. 
Schweizer, A., 2001. Archäopalynologische Untersuchungen zur Neolithisierung der nördlichen Wetterau. Mit einem methodischen Beitrag zur Pollenanalyse in Lößgebieten. Dissertationes Botanicae 158pp.

Semmel, A., 1995. Bodenkundliche Hinweise auf Ackernutzung und intensive Bodenerosion um 8000 B.P. im Rhein-Main-Gebiet. Archäologisches Korrespondenzblatt 25, 157-163.

Stehli, 1989. Merzbachtal Umwelt und Geschichte einer Bandkeramischen Siedlungskammer. Germania 67, 51-76.

Stobbe, A., 1996. Die holozäne Vegetationsgeschichte der nördlichen Wetterau. Paläoökologische Untersuchungen unter besonderer Berücksichtigung anthropogener Einflüsse. Dissertationes Botanicae, $216 \mathrm{pp}$.

Strien, H.C., Tilmann, A., 2001. Die La-Hoguette-Fundstelle von Stuttgart-Bad Cannstatt: Archäologie. In: Gehlen, B., Heinen, M., Tilmann, A. (Eds.), Zeit-Räume - Gedenkschrift für Wolfhang Taute. Archäologische Berichte 14, 673-681.

Sugita, S., 1998. Modelling pollen representation of vegetation. In: Gaillard, M.-J., Berglund, B.E. (Eds.), Quantification of Land Surfaces Cleared of Forest during the Holocene - Modern Pollen/ Vegetation/Landscape Relationships as an Aid to the Interpretation of Fossil Pollen Data. Paläoklimaforschung, 27, 1-16.

Tegtmeier, U., 1993. Neolithische und bronzezeitliche Pflugspuren in Norddeutschland und den Niederlanden. Archäologische Berichte (Bonn) 3, 143pp.

Thiemeyer, H., 1989. Holozäne Dellenentwicklung durch Bodenerosion - Beispiele aus Lößgebieten. Bayreuther geowissenschaftliche Arbeiten 14, 95-102.

Thiemeyer, H., 1991. Geomorphologische und bodenkundliche Aspekte des bandkeramischen Siedlungsplatzes Friedberg-Bruchenbrücken, Wetteraukreis. Wetterauer Geschichtsblätter 40, 107-116.

Troels-Smith, J., 1954. Ertebøllekultur - Bondekultur. Resultater af de sidste 10 Aars Undersøgelser i Aamosen, Vestsjælland. Aarbøger 1953 (1954), 5-46.

Urz, R., 1995. Jungquartär im Auenbereich der mittleren Lahn. Stratigraphische und paläontologische Untersuchungen zur Rekonstruktion vergangener Flußlandschaften. Dissertation Fachbereich Geowissenschaften Universität Marburg, 219pp.

Urz, R., 2000. Begraben unter Auelehm: Frühmesolithische Siedlungsspuren im mittleren Lahntal. Archäologisches Korrespondenzblatt $30 / 1,33-43$.
Voigt, R., Baier, J., Herking, CH., Grüger, E., Meischner, D., 2000. Lake Jues in Herzberg, Harz Mountains. Sedimentology, geochemistry, palynology and diatomology of laminated limnic muds. In Andres, W. (Ed.), Final Colloquium of the DFG priority programme "Changes of the Geo- Biosphere during the last 15.000 years", http:// www.uni-frankfurt.de/fb11/ipg/spp/postergallery/ Poster_gif/ Poster_Voigt_etal.gif., Bonn.

Weiner, J., 1992. Der älteste erhaltene Holzbau der Welt-Ein Brunnen der Linearbandkeramik aus Erkelenz-Kückhoven. Archäologie in Deutschland 1992 (1), 54-55.

Weninger, B., Norkus, E., Velicky, P, Freundlich, J., 2001. The Köln University Laboratory (1963-2000). In: Gehlen, B., Heinen, M., Tilmann, A. (Eds.), Zeit-Räume - Gedenkschrift für Wolfgang Taute. Archäologische Berichte 14, 33-41.

Willerding, 1980. Zum Ackerbau der Bandkeramiker. In: Krüger, Th., Stephan, H.G. (Eds.), Beiträge zur Archäologie Nordwestdeutschlands und Mitteleuropas. Materialhefte zur Ur- und Frühgeschichte in Niedersachsen 16, 421-456.

Wunderlich, J., 1998. Palökologische Untersuchungen zur spätglazialen und holozänen Entwicklung im Bereich der Hessischen Senke - ein Beitrag zur internationalen Global Change-Forschung. Habilitation thesis, Universität Marburg, 206pp.

Wunderlich, J., 2000. Prähistorische und historische Bodenerosion im Amöneburger Becken - Abgeleitet aus einer Sequenz datierter Kolluvien. Berichte der Kommission für Archäologische Landesforschung in Hessen 5, 9-15.

Wurth, G.,Niggemann, S., Frank, N., Mangini, A., Richter, D.K., 2000. Jungquartäre Stalagmiten aus Höhlen des Gottesackergebietes (Allgäuer Alpen) als Archiv für Paläoumweltbedingungen. Karst und Höhle 2000, 183-197, München.

Zink, K.-G., Leythaeuser, D., Mayer, B., Lechterbeck, J., Schwark, L., 2000. Variations in geochemical composition of laminated sediments from Lake Steißlingen (SW-Germany), induced by postglacial paleoenvironmental/climatic and anthropogenic processes. In: Andres, W. (Ed.), Final Colloquium of the DFG priority programme "Changes of the Geo-Biosphere during the last 15.000 years". http:// www.uni-frankfurt.de/fb11/ipg/spp/postergallery/ Poster_gif/, Bonn

Zolitschka, B., 1998. Paläoklimatische Bedeutung laminierter Sedimente. Relief, Boden, Paläoklima 13, 176pp, Borntraeger, Berlin, Stuttgart. 